\title{
Comparison between metamizole and triptans for migraine treatment: a systematic review and network meta-analysis
}

\author{
Mario Fernando Prieto Peres ${ }^{1}$ (D), Wanessa Alessandra Ruiz Scala² ${ }^{\text {iD }}$, Ricardo Salazar ${ }^{3}$ \\ 'Instituto de Psiquiatria, Hospital das Clínicas da FMUSP, Brazil \\ 2Sanofi Pharmaceuticals, CHC Brazil Medical Affairs, Brazil \\ ${ }^{3}$ Regional Medical Head LATAM, Government and Public Affairs \& Advocacy for Latin America, Consumer Healthcare, Sanofi, Brazil
}

$凶$

Mario Fernando Prieto Peres marioperes@yahoo.com

Edited by

Marcelo Moraes Valença

Keywords:

Metamizole

Triptans

Migraine disorders

Headache

Tension-type headache

Dipyrone

\begin{abstract}
Objective

The aim of this systematic review was to evaluate the efficacy of metamizole and triptans for the treatment of migraine.

Methods

Randomized controlled trials including people who received metamizole or triptan by multiple routes of administration and at all doses as treatment compared to subjects who received another treatment or placebo were included in the systematic review. The primary outcomes were freedom from pain at 2 hours; pain relief at 2 hours; sustained headache response at 24 hours; sustained freedom from pain at 24 hours. The statistical analysis of all interventions of interest were based on random effect models compared through a network meta-analysis.

Results

209 studies meeting the inclusion and exclusion criteria were analyzed. Of these, $130 \mathrm{had}$ data that could be analyzed statistically. Only $3.0 \%$ provided enough information and were judged to have a low overall risk of bias for all categories evaluated; approximately $50 \%$ of the studies presented a low risk of selection bias. More than $75 \%$ of the studies presented a low risk of performance bias, and around $75 \%$ showed a low risk of detection and attrition bias.

Conclusion

There is no evidence of a difference between dipyrone and any triptan for pain freedom after 2 hours of medication. Our study suggests that metamizole may be equally effective as triptans in acute migraine treatment.
\end{abstract}




\section{Introduction}

M igraine is a highly prevalent condition manifesting as moderate or severe intermittent headache attacks with associated symptoms, lasting 4 to 72 hours if not properly treated. ${ }^{1-3}$

Migraine is not only a headache but also a syndrome of various phases, each with its own distinct mechanisms and treatment approaches. Briefly, the migraine prodrome, or premonitory phase, can occur several hours to days before a headache and may be hypothalamically modulated, although other brainstem and limbic structures may play a causal role as well. ${ }^{4}$

The relationship between migraine and cognition is complex. Cognitive symp-toms are part of the subjective experience of migraine attacks and contribute to attackrelated disability, interfering with work performance, family and social life, besides self-management of the attacks. This transient impairment may occur along all phases of a migraine attack. While pain is the main determinant of disability, cognitive dysfunction also contributes to attack-related impairment, and should be considered as a migraine therapeutic target, together with pain, to evaluate the efficacy of an acute attack treatment. ${ }^{5}$

While it is clear that migraine attacks include some degree of cognitive impair-ment, in the long run, migraine is not associated with any significant impact on cognitive performance or age-associated cognitive decline in the general popu-lation. So, acute cognitive dysfunction during a migraine attack is reversible. However, individuals with more severe and frequent migraine attacks and sub-jects with chronic migraine tend to maintain cognitive difficulties between at-tacks. ${ }^{5}$

The acute management of migraines includes the use of non-steroidal anti-inflammatory drugs (NSAIDs), acetaminophen, metamizole, ergots, and triptans. Gepants and ditans have been recently added to the list. ${ }^{6}$

Metamizole is a well-established and highly used drug to treat acute attacks in emergency settings in Brazil, as well as the most common analgesic medication used for migraine treatment in the population. ${ }^{7,8}$

Triptans represent a large therapeutic group with a good therapeutic profile, but their vasoconstriction adverse events warrant caution in patients with cardio-vascular risk. Other side effects, such as nausea, dizziness and chest symptoms, preclude some patients from using triptans, while a few patients do not respond well to triptans. Compliance and tolerability of triptans are certainly different for each medicine. Triptans are considered to be safe, with a very low potential risk of clinically significant serious adverse events. Contraindications to triptan use include uncontrolled hypertension, ischemic heart disease, coronary vasospasm, cerebrovascular disease, peripheral vascular disease, and basilar or hemiplegic migraine. 9,10

Metamizole and triptans are both major medications in the acute therapy arse-nal, however, they have never been directly compared.

To evaluate the efficacy of metamizole and triptans for the treatment of migraine, we conducted this systematic review and network meta-analysis to address the following focused questions: (1) "what is the evidence for the efficacy and safety of metamizole for the treatment of migraines compared with triptans?" and (2) "how effective are those treatments in improving cognitive dysfunction in patients with migraine?"

\section{Methods}

TThe systematic review has been developed in accordance with the Preferred Reporting Items for Systematic Reviews and Meta-Analyses Protocols (PRISMA) statement ${ }^{11-13}$, using methodology described in the Cochrane Handbook for Systematic Review of Interventions. ${ }^{14}$ This protocol was registered within the PROSPERO database (CRD42020216360).

\section{Study eligibility criteria}

Only randomized controlled trials reporting study-specific data for migraine outcomes in people who received metamizole or triptan as treatment were included in the systematic review. The population of interest was participants with migraine, of any age, gender and severity of migraine. We have used investigator-reported definitions (according to accepted diagnostic criteria, such as the International Classification of Diseases, or according to the criteria established by the International Headache Society). ${ }^{15}$ We examined papers from all countries, subjects who have used metamizole or triptan treatment (test group), by multiple routes of administration (tablets, oral disintegrating tablets, injection, transdermal, nasal spray, rectal suppositories) and at all doses (any frequency or strength), compared to subjects who have 
received another treatment or placebo. Metamizole and Triptans were not allowed to be used in combination with other drugs. The primary outcomes were freedom from pain at 2 hours; pain relief at 2 hours; sustained headache response at 24 hours; sustained freedom from pain at 24 hours. Secondary outcomes were relief of other symptoms associated with migraine, specifically nausea, vomiting, photophobia and phonophobia, fatigue, dizziness, cognitive impairment, any adverse effects (AEs), withdrawals due to adverse events, use of rescue medication, patient satisfaction, absenteeism, functional disability and quality of life.

We excluded studies in which metamizole or triptan was not the intervention of interest, studies comparing combined metamizole preparations with another treatment, studies comparing combined triptan preparations with another treatment, studies where metamizole or triptan have not been studied in only one separate intervention group, studies in which migraine is not reported as the outcome of interest, studies that do not have adequate information regarding whether metamizole or triptan and its derivatives are not related to migraine improvement, studies involving secondary headache disorders (post-puncture headache, post-traumatic headache, cancer-related headache etc.), studies that do not have adequate information on the classification of primary headache or animal studies. There was no restriction of study setting.

\section{Information sources}

We searched the literature in the following databases: MEDLINE via PubMed, EMBASE, LILACS, EbscoHost and all references of the included studies, with no language restrictions from inception to November 2020. MesH terms and keywords were combined with Boolean operators and used as search strategies: \# 1 - migraine OR headache OR "tension-type headache"; \#2 - dipyrone OR metamizole; \#3 - triptan OR sumatriptan OR zolmitriptan OR rizatriptan $O R$ naratriptan $O R$ frovatriptan $O R$ almotriptan $O R$ eletriptan; \#4 - \#1 AND \#2; \#5 - \# 1 AND \#3; \#6 - \#4 OR \#5. Two reviewers screened all articles identified from the search independently. Any disagreements between reviewers were solved by discussion with a third reviewer to meet a consensus. Studies meeting the inclusion criteria underwent a validity assessment and data extraction. Reasons for rejecting studies were recorded for each study.

\section{Data extraction (study characteristics and results) / Data management}

Two reviewers extracted data independently. Disagreements were solved with discussion with a third reviewer. Data were transferred to Excel sheets for analysis. Measures of central tendency (mean or median) and dispersion (standard deviations and percentiles) for different biometric parameters were extracted. For continuous outcomes, the following was extracted: means, SD and sample sizes at baseline and follow-up. If these were unavailable, change scores or mean differences were extracted. For dichotomous outcomes, the number of cases and total sample size were extracted. Safety outcomes included the number of participants reporting any or serious $A E s$ or withdrawn from the study because of AEs.

All interventions of interest were compared through a network meta-analysis. A graph summarized the results of interest, allowing us to easily assess the structure of existing evidence.

\section{Risk of bias within individual studies}

The risk of bias of the included studies was evaluated according to the Cochrane Collaboration's Tool for Assessing Risk of Bias. ${ }^{14}$ Briefly, randomization and allocation methods (selection bias), completeness of follow-up period/incomplete outcome data (attrition bias), masking of patients (performance bias) and examiners (defection bias), selective reporting (reporting bias), and other forms of bias were classified as adequate $(+)$, inadequate (-), or unclear (?). Based on these domains, the overall risk of bias was categorized as follows: 1) low risk of bias; 2) unclear risk of bias; or 3) high risk of bias.

\section{Summary measures}

To inform on comparative efficacy, effectiveness, and safety between all interventions, we conducted a network meta-analysis. We modeled log odds ratios using the conventional logistic regression network meta-analysis setup. ${ }^{16}$ The network meta-analysis was based on logistic model with random study effects. ${ }^{17}$

\section{Assessment of inconsistency}

Consistency was assessed by comparison of the conventional network meta-analysis model for which consistency was assumed with a model that does not assume consistency (a series of pairwise meta-analyses analyzed jointly). If the trade-off between model fit and complexity favors the model with assumed consistency, this model was preferred. Moreover, we calculated the difference between direct and indirect evidence in all closed loops in the network; inconsistent loops were 
identified with a significant $(95 \% \mathrm{Cl}$ that excludes 0$)$ disagreement between direct and indirect evidence.

\section{Risk of bias across studies}

Publication bias or small study effects were assessed by inspection of the funnel plots for asymmetry and with Egger's test ${ }^{18}$ and Begg's test ${ }^{19}$, with the results considered to indicate potential small study effects when $p<0.10$.

\section{Results}

The search identified 4,003 articles. After excluding duplicate references, a total of 1,601 titles and abstracts retrieved from electronic databases and hand searching were analyzed. Based on the eligibility criteria, the texts of 450 publications were reviewed in full. Of these, 198 were eligible according to the inclusion and exclusion criteria (see Figure 1). Ten articles published results from more than one study, thus 209 studies were analyzed. ${ }^{20-29}$

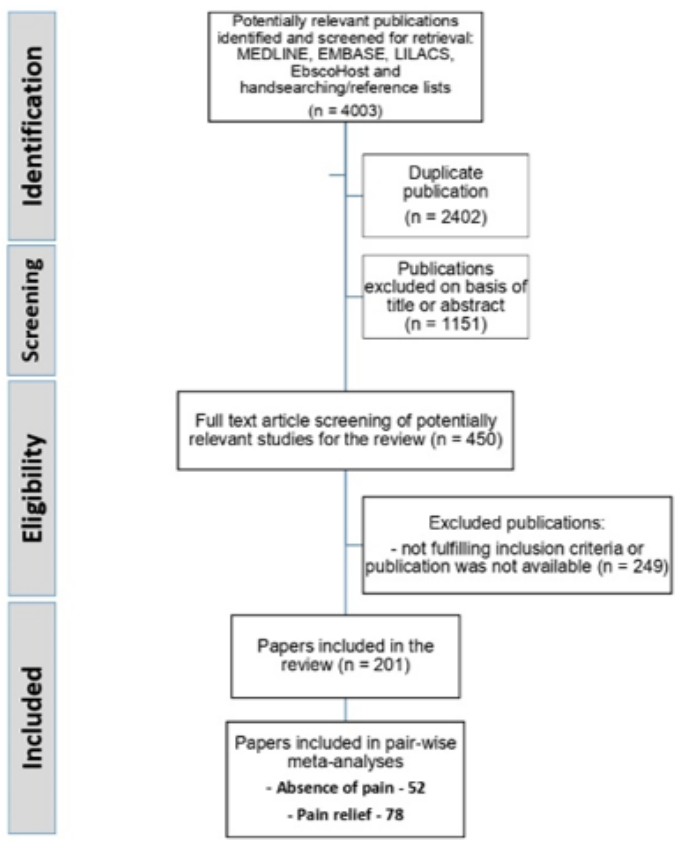

Figure 1. Diagram.

All of the included studies were published between 1991 and 2019. Most of them were large, multicenter, doubleblind, placebo-controlled trials conducted in a variety of countries in the five continents.

The number of randomized patients who received some treatment totaled 94,570 subjects, diagnosed with migraine headaches according to the International Headache Society criteria for migraine. Excluding four studies that did not mention participants' sexes30-33, female participants were the majority, with approximately $84.2 \%$.

The types of treatments varied widely both in dosage and route of administration. The seven types of triptans (almotriptan, eletriptan, frovatriptan, naratriptan, rizatriptan, sumatriptan, and zolmitriptan) appeared among the selected studies. However, sumatriptan was the most common and was found in 18 different variations: it appeared with oral, subcutaneous, nasal spray, iontophoretic transdermal patch (TDS) and suppository administration, combining dosages from $1 \mathrm{mg}$ to $200 \mathrm{mg}$.

Some treatment arms used triptan in combination therapies with other drugs: frovatriptan $2.5 \mathrm{mg}+$ dexketoprofen $25 \mathrm{mg}$ or $37.5 \mathrm{mg}^{34}$; naratriptan $2.5 \mathrm{mg}$ orally + rectal suppository of prochlorperazine $25 \mathrm{mg}^{35}$; rizatriptan 10 $\mathrm{mg}+$ acetaminophen $1,000 \mathrm{mg}$ orally ${ }^{36}$, and rizatriptan $10 \mathrm{mg}+$ dexamethasone $4 \mathrm{mg}$ orally ${ }^{37}$. All studies with combination therapy included in this review had an exclusive triptan arm and a placebo comparative arm.

Only 6 studies with metamizole to treat migraine (dosage of $500 \mathrm{mg}$ and $1,000 \mathrm{mg}$ orally and IV) met all the inclusion criteria to be considered in this systematic review. Four studies utilizing the intravenous metamizole route were performed in Brazi| ${ }^{8,38-40}$, one in Spain ${ }^{41}$ and the last one in Turkey ${ }^{42,43}$, with the last two studies including oral metamizole.

Most studies included in this review were conducted in the adult population and only 13 were carried out with adolescents. ${ }^{43.55}$

Most of the selected studies evaluated improvement or complete relief of headache after 1 hour, 2 hours and in the first 24 hours, although some studies have evaluated different times of symptomatic relief after 30 minutes, in addition to the use of rescue medication in the period. Some studies have evaluated relief of migraine-associated symptoms, such as photophobia, phonophobia, nausea and vomiting. The characteristics of the included studies is in supplementary table (Table 1).

The results of the risk of bias assessment are shown in figure 2. Of all 209 studies, only six (3.0\%) provided enough information and were judged to have a low overall risk of bias for all categories evaluated; 146 studies had insufficient information, mainly in the selective reporting domain, so the overall risk of bias was unclear, and 46 presented a high overall risk of bias. 


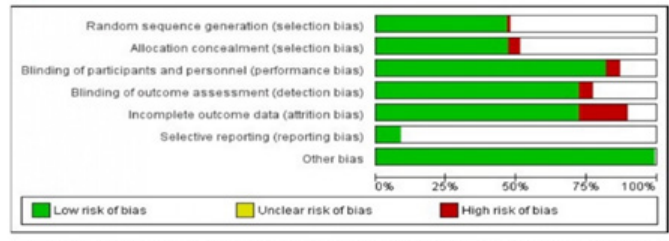

Risk of bias graph: rover

Figure 2. Risk of bias graph: review authors' judgements about each domain presented as percentages across all included studies.

Approximately $50 \%$ of the studies presented a low risk of selection bias. More than $75 \%$ of the studies presented a low risk of performance bias, and around $75 \%$ have shown a low risk of detection and attrition bias.

The statistical analysis below was based on random effect models from network meta-analyses. The calculations were made with the netmeta package of the $\mathrm{R}$ library, developed by Rücker et al. ${ }^{56}$ and based on the methodology described in Schwarzer et al. ${ }^{57}$

Since there are no direct comparisons of dipyrone versus any of the triptans, consistency tests were not performed.

\section{Pain freedom after 2 hours of medication}

Figure 3 illustrates the connections between the active substances. The thickness of the edges indicates the weights of the direct comparisons. Studies with more than two treatments were excluded in this analysis. ${ }^{20,36}$

There is no evidence of a difference between dipyrone and any triptan.

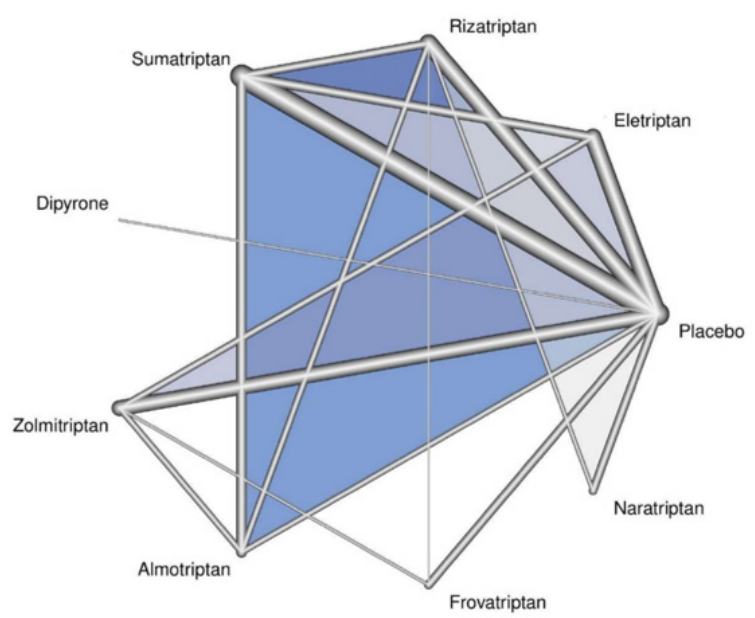

Figure 3. Network graph for pain-free data after 2 hours of medication.

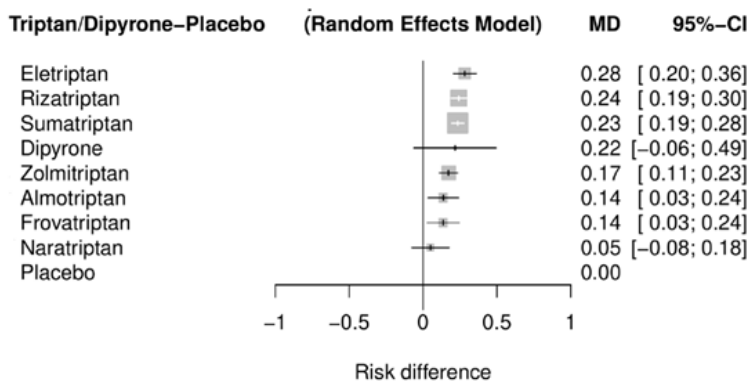

Figure 4. Estimates of the effect of triptans and dipyrone in relation to placebo.

\section{Pain relief after 2 hours of medication}

Figure 5 illustrates the connections between the active substances.

The confidence intervals for differences in pain relief ratios after 2 hours of medication between triptan and placebo versus dipyrone are shown in the forest plot. There is no evidence of a difference between dipyrone and any triptan.

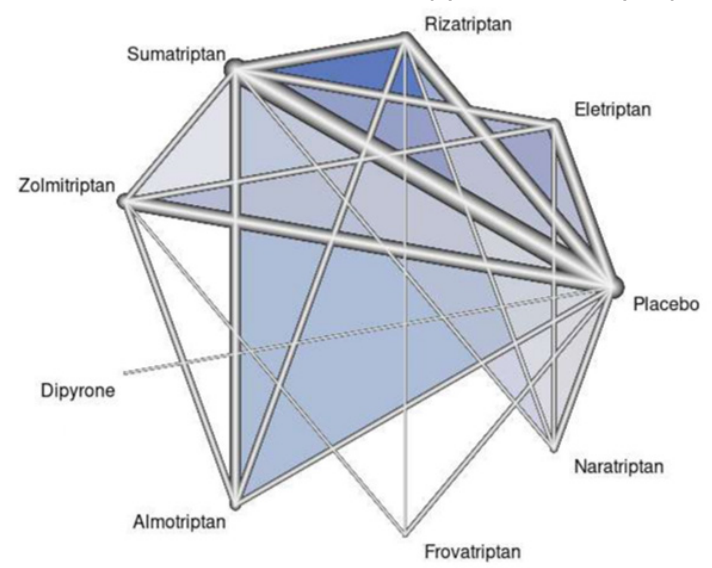

Figure 5. Network graph for pain relief data after 2 hours of medication.

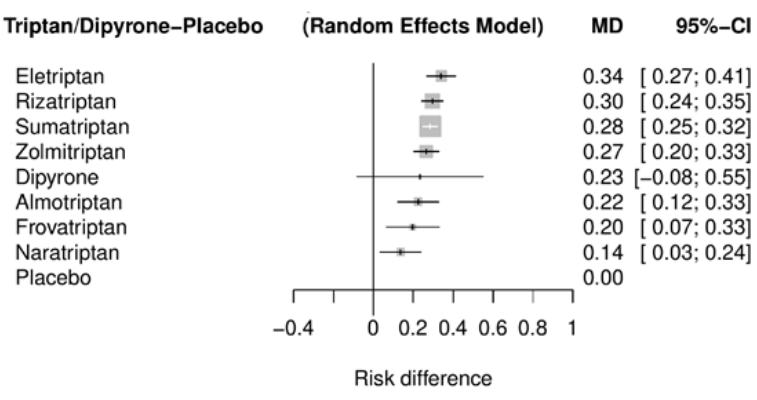

Figure 6. Estimates of the effect of triptans and dipyrone in relation to placebo. 
Table 1. Characteristics of Included Studies

\begin{tabular}{|c|c|c|c|}
\hline $\begin{array}{l}\text { Author, publica- } \\
\text { tion year }\end{array}$ & Population & Comparisons & Outcomes \\
\hline Ahonen et al. ${ }^{44}$ & $\begin{array}{l}\text { Children/Adolescents }-12.4 \\
\text { (SD 2.4, range } 8.1 \text { to } 17.5 \text { ) } \\
\text { years } \\
n=94(51 \text { boys and } 43 \text { girls) }\end{array}$ & $\begin{array}{l}\text { Sumatriptan } 10 \mathrm{mg} \text { (20 to } 39 \\
\mathrm{~kg} \text { ) } \\
\text { Sumatriptan } 20 \mathrm{mg} \text { ( } \geq 40 \mathrm{~kg} \text { ) } \\
\text { Placebo } \\
\text { A single dose of sumatriptan } \\
\text { nasal spray and a matching } \\
\text { placebo were administered at } \\
\text { home during two attacks. }\end{array}$ & $\begin{array}{l}\text { The primary efficacy endpoint was headache relief by two grades } \\
\text { on a } 5 \text {-grade face scale at } 2 \text { hours. } \\
\text { Sumatriptan (n 53/83; 64\%); placebo (n 32/83; 39\%) }\end{array}$ \\
\hline Ahonem et al. ${ }^{43}$ & $\begin{array}{l}\text { Adolescents }-12.0 \text { years (SD } \\
2.4 ; \text { range } 6.1 \text { to } 16.1 \text { years) } \\
\mathrm{n}=116 \text { (63 girls and } 53 \text { boys) }\end{array}$ & $\begin{array}{l}\text { Oral rizatriptan } 5 \mathrm{mg} \text { ( } 20 \text { to } \\
39 \mathrm{~kg}) \text {; } \\
\text { Oral rizatriptan } 10 \mathrm{mg}(40 \mathrm{~kg} \\
\text { or more); } \\
\text { Placebo } \\
\text { Two doses of rizatriptan and } \\
\text { a matching placebo were } \\
\text { administered at home during } \\
\text { three attacks. }\end{array}$ & $\begin{array}{l}\text { Ninety-six patients used all three treatments, } 10 \text { used two, and } \\
10 \text { only the first. At } 2 \text { hours, the primary endpoint (headache } \\
\text { relief by two grades on a five-grade face scale at } 2 \text { hours) was } \\
\text { reached twice as often after both treatments of rizatriptan [first } \\
n=71 / 96(74 \%) \text {; second } n=70 / 96(73 \%)] \text { as after placebo [n } \\
=35 / 96(36 \%) \text { ] ( } p<0.001) \text {. Already at } 1 \text { hour, rizatriptan was } \\
\text { clearly more effective as headache relief was reported by } 50 \% \\
(n=48 / 96) \text { and } 55 \%(n=53 / 96) \text { of children after the first and } \\
\text { the second dose of rizatriptan, compared to } 29 \%(n=28 / 96) \\
\text { after placebo ( } p=0.004) \text {. Rizatriptan was superior at } 3 \text { and } 4 \\
\text { hours, and the other endpoints also favored rizatriptan. Efficacy } \\
\text { of rizatriptan was constant over the two treated attacks, and the } \\
\text { findings were similar in children using the dose of } 5 \text { and } 10 \text { mg. } \\
\text { The use of the higher } 10 \text { mg adult dose in adolescents caused } \\
\text { adverse effects with a frequency comparable to what has been } \\
\text { observed in adults. But no serious adverse effects were observed. }\end{array}$ \\
\hline Ahrens et al. ${ }^{58}$ & $\begin{array}{l}\text { Adults - } \\
\text { Placebo - } 41.6 \text { ( } 18 \text { to } 72 \text { ) } \\
\text { years; Rizatriptan } 5 \text { mg - } 42.7 \\
\text { ( } 19 \text { to 67) years; Rizatriptan } 10 \\
\text { mg } 43.1 \text { (19 to } 67 \text { ) years. } \\
\mathrm{n}=555 \text { ( } 64 \text { male and } 491 \\
\text { female) }\end{array}$ & $\begin{array}{l}\text { Rizatriptan } 10 \mathrm{mg} \\
\text { Rizatriptan } 5 \mathrm{mg} \\
\text { Placebo } \\
\text { Single attack }\end{array}$ & $\begin{array}{l}\text { The primary efficacy endpoint was pain relief at } 2 \mathrm{~h} \text {. From } 30 \text { min } \\
\text { onwards, significantly more patients experienced pain relief and } \\
\text { became pain-free after rizatriptan } 10 \mathrm{mg} \text { compared to placebo. } \\
\text { At } 2 \mathrm{~h} \text {, the percentage of patients with pain relief was significantly } \\
\text { higher after rizatriptan } 10 \mathrm{mg}(74 \%), 5 \mathrm{mg}(59 \%) \text { compared with } \\
\text { placebo ( } 28 \%) \text {. Rizatriptan } 10 \mathrm{mg} \text { was superior to rizatriptan } 5 \\
\text { mg on pain relief at } 1.5 \text { and } 2 \mathrm{~h}(\mathrm{p}<0.05) \text {. Significantly more } \\
\text { patients were pain-free at } 2 \mathrm{~h} \text { after rizatriptan } 10 \mathrm{mg}(42 \%), 5 \\
\text { mg wafer ( } 35 \%) \text { compared with placebo (10\%). Both doses of } \\
\text { rizatriptan wafer were well tolerated. }\end{array}$ \\
\hline Akpunon et al. ${ }^{59}$ & $\begin{array}{l}\text { Adults - } \\
\text { Plac - 39.8 (SD 9.4) - } 22 \text { to } 59 \\
\text { SUM - } 39.8 \text { (SD 10) - } 22 \text { to } 71 \\
\text { years; } \\
\text { n=136 ( } 17 \text { Male; } 119 \text { Female) } \\
\text { Sum - Male } 10 \text { (1 1\%); Female } \\
78(89 \%)\end{array}$ & $\begin{array}{l}\text { Sumatriptan } 6 \mathrm{mg} \mathrm{SC} \\
\text { Placebo }\end{array}$ & $\begin{array}{l}\mathrm{N}^{\circ} \text { of patients with meaningful relief - Plac } 17 \text { (35\%); Sum } 66 \\
(75 \%) \text { Time to meaningful relief (min) median- Plac } 66 \text {; Sum } 43 \\
\mathrm{~N}^{\circ} \text { of patiens with nopain or mild pain at discharge - Plac } 17 \\
(35 \%) \text {; Sum } 62 \text { (70\%) } \\
\mathrm{N}^{\circ} \text { of patients with no pain at discharge - Plac } 6(13 \%) \text {; Sum } \\
27(31 \%)\end{array}$ \\
\hline Allais et al..$^{60}$ & $\begin{array}{l}\text { Adults }-34.92 \pm 7.99 \text { years } \\
n=122 \text { (all female) }\end{array}$ & $\begin{array}{l}\text { Almotriptan } 12.5 \mathrm{mg} \text { oral } \\
\text { Placebo } \\
\text { One single menstrual migraine } \\
\text { attack per menstrual cycle } \\
\text { was treated in four different } \\
\text { menstrual cycles. }\end{array}$ & $\begin{array}{l}\text { Data suggest that almotriptan shows excellent efficacy on } \\
\text { menstrual migraine in comparison to the placebo, with a } \\
\text { significant reduction in the percentages of suffering patients } \\
\text { over a } 2 \text {-h period of time. }\end{array}$ \\
\hline Allais et al. ${ }^{61}$ & $\begin{array}{l}\text { Adults }-34.9 \pm 8.0 \text { ( } 18 \text { to } 50) \\
\text { years } \\
n=147 \text { (all females) }\end{array}$ & $\begin{array}{l}\text { Almotriptan } 12.5 \mathrm{mg} \text { oral } \\
\text { Placebo } \\
\text { One tablet after pain onset } \\
\text { during two menstrual cycle }\end{array}$ & $\begin{array}{l}\text { Significantly more patients were pain-free at two hours (risk ratio } \\
[R R]=1.81 ; p=0.0008), \text { pain-free from } 2-24 \text { hours with no } \\
\text { rescue medication (RR }=1.99 ; p=0.0022) \text {, and pain-free from } \\
2-24 \text { hours with no rescue medication or adverse events (RR = } \\
1.94 ; p=0.0061 \text { ) with almotriptan versus placebo. Nausea } \\
(p=.0007) \text { and photophobia } p=0.0083) \text { at two hours were } \\
\text { significantly less frequent with almotriptan. Almotriptan efficacy } \\
\text { was consistent between three attacks, with } 56.2 \% \text { of patients } \\
\text { pain-free at two hours at least twice. Adverse events were similar } \\
\text { with almotriptan and placebo. }\end{array}$ \\
\hline Almas et al. ${ }^{62}$ & $\begin{array}{l}\text { Adults - eletriptan- } 40 \mathrm{mg}: \\
41.7 \pm 10.7 \text { years; eletriptan- } 80 \\
\text { mg: } 41.7 \pm 10.3 \text { years. } \\
\mathrm{n}=971 \text { ( } 803 \text { females and } 168 \\
\text { males) } \\
\text { [eletriptan- } 40 \mathrm{mg}: 453 \text { females } \\
\text { and } 86 \text { males; eletriptan-80 } \\
\text { mg: } 350 \text { females and } 82 \\
\text { males;] }\end{array}$ & $\begin{array}{l}\text { Eletriptan } 40 \text { mg or } 80 \mathrm{mg} \\
\text { Placebo } \\
\text { four-attack consistency of } \\
\text { response study in which three } \\
\text { attacks were treated with ELE- } 40 \\
\text { or ELE-80, and one randomly } \\
\text { chosen attack was treated with } \\
\text { placebo }\end{array}$ & $\begin{array}{l}\text { On a repeated measure logistic regression analysis across all } \\
\text { treated attacks, the probability of achieving a headache response } \\
\text { at } 2 \text { hours ranged from } 71 \% \text { to } 74 \% \text { on ELE- } 40 \text { vs. } 17 \% \text { to } 28 \% \text { on } \\
\text { placebo ( } p<0.0001) \text {, and from } 66 \% \text { to } 74 \% \text { on ELE- } 80 \text { vs. } 21 \% \\
\text { to } 27 \% \text { on placebo }(p<0.0001) \text {. The incidence, per attack, of } \\
\text { adverse events, was low for both ELE- } 40 \text { and ELE- } 80 \text {. Few adverse } \\
\text { events occurred with incidence } \geq 10 \% \text { on ELE- } 40 \text { (asthenia, } 5.0 \% \text { ) } \\
\text { or ELE- } 80 \text { (asthenia, } 10 \% \text {; nausea, } 5.8 \% \text { ). Discontinuations } \\
\text { because of adverse events were } 0.2 \% \text { on ELE-40, and } 1.6 \% \text { on } \\
\text { ELE-80. (ELE: eletriptan) }\end{array}$ \\
\hline $\begin{array}{l}\text { Baneriee, } \\
\text { Findley }^{63^{3}}\end{array}$ & $\begin{array}{l}\text { Adults - } 18 \text { to } 65 \text { years (mean } \\
35 \text { years) } \\
n=94 \text { ( } 80 \text { female; } 14 \text { male) }\end{array}$ & $\begin{array}{l}\text { Sumatriptan } 200 \mathrm{mg} \text { oral } \\
\text { Placebo } \\
\text { Up to three attacks }\end{array}$ & $\begin{array}{l}\text { Each patient was treated for a maximum of three separate attacks } \\
\text { of migraine with aura within a three months' period. Three attacks } \\
\text { were treated so that we could examine consistency of response } \\
\text { across more than one attack. For attack } 1,200 \mathrm{mg} \text { sumatriptan } \\
\text { was significantly more effective, safe and well tolerated than } \\
\text { placebo at relieving headache } 2 \mathrm{~h} \text { after treatment was given } \\
\text { ( } \mathrm{p}=0.023 \text { ). In subsequent attacks, i.e. in attacks } 2 \text { and } 3 \text {, there } \\
\text { was no such significant effect of sumatriptan compared with } \\
\text { placebo in relieving headache }\end{array}$ \\
\hline
\end{tabular}




\begin{tabular}{|c|c|c|c|}
\hline Barbanti et al. ${ }^{64}$ & $\begin{array}{l}\text { Adults: } 41 \text { years }[(41.5 \pm 11.9 \\
\text { years sumatriptan } 50 \mathrm{mg}, \\
39.7 \pm 10.3 \text { years sumatriptan } \\
100 \mathrm{mg}, 40.6 \pm 10.3 \text { years } \\
\text { placebo)] } \\
\mathrm{n}=432 \text { ( } 358 \text { females and } 74 \\
\text { males) }\end{array}$ & $\begin{array}{l}\text { Sumatriptan } 50 \mathrm{mg} \text { or } 100 \\
\text { mg oral } \\
\text { Placebo } \\
\text { Single migraine attack }\end{array}$ & $\begin{array}{l}\text { Normal functional ability was restored in a significantly }(\mathrm{p}<0.05) \\
\text { greater percentage of patients treated with sumatriptan than } \\
\text { placebo beginning } 45 \text { min postdose for sumatriptan } 100 \mathrm{mg} \\
\text { and } 1 \mathrm{~h} \text { postdose for sumatriptan } 50 \mathrm{mg} \text {. During the } 24 \mathrm{~h} \text { after } \\
\text { initial dosing, the median (range) lost time equivalents for the } \\
\text { combination of paid work activities and activities outside of } \\
\text { paid work were significantly lower in the groups treated with } \\
\text { sumatriptan ( } 1.1 \text { - } 0 \text { - } 10 \text { ] sumatriptan } 100 \mathrm{mg} ; 0.8 \text { [0-36] } \\
\text { sumatriptan } 50 \mathrm{mg} \text { ) compared with placebo }(2.9 \text { [0-24]) ( } \mathrm{p} \leq 0.01 \\
\text { each sumatriptan group versus placebo). The corresponding } \\
\text { mean }+/-\mathrm{SD} \text { values for lost time equivalents were } 1.9 \pm 2.3 \\
\text { and } 2.5 \pm 4.7 \text { for sumatriptan } 100 \mathrm{mg} \text { and } 50 \text { mg, respectively, } \\
\text { compared with } 3.5 \pm 4.3 \text { for placebo. }\end{array}$ \\
\hline Barbanti et al. ${ }^{65}$ & $\begin{array}{l}\text { Adults - } \\
\text { Rizatriptan }=43.95 \pm 12.24 \\
\text { Placebo = 41.41 } \pm 11.7 \\
\mathrm{n}=80 \text { (13 male; } 67 \text { female) }\end{array}$ & $\begin{array}{l}\text { Rizatriptan } 10 \mathrm{mg} \\
\text { Placebo } \\
\text { Single migraine attack }\end{array}$ & $\begin{array}{l}\text { The primary endpoints were pain freedom at } 2 \mathrm{~h} \text { and total } \\
\text { migraine freedom (pain freedom and absence of associated } \\
\text { symptoms) at } 2 \mathrm{~h} \text {. } \\
\text { Pain freedom } 2 \mathrm{~h} \text { - Rizatriptan } 54 \% \text { vs Placebo } 8 \%(\mathrm{p}<0.001) \text { ) } \\
\text { Migraine freedom } 2 \mathrm{~h} \text { - Rizatriptan - } 51 \% \text { vs Placebo } 8 \%(\mathrm{p}<0.001) \\
\text { Binomial regression analysis showed that a significantly larger } \\
\text { percentage of patients assigned to rizatriptan than to placebo } \\
\text { reported pain freedom at } 2 \mathrm{~h} \text { post dosing (54\% [ } 95 \% \mathrm{Cl} 38 \text {, } \\
70 \%] \text { vs. } 8 \% \text { [95 } \% \mathrm{Cl}-1,17 \%] \text { ) (p<0.001) and total migraine } \\
\text { freedom at } 2 \mathrm{~h} \text { post dosing }(51 \% \text { [95 } \% \mathrm{Cl} 36,67 \%] \text { vs. } 8 \% \\
[95 \% \mathrm{Cl}-1,17 \%])(\mathrm{p}<0.001)\end{array}$ \\
\hline Bartolini et al. 66 & $\begin{array}{l}\text { Adults }-40 \pm 10 \text { years } \\
\mathrm{n}=114 \text { (96 female; } 18 \text { male) }\end{array}$ & $\begin{array}{l}\text { Frovatriptan } 2.5 \mathrm{mg} \\
\text { Almotriptan } 12.5 \mathrm{mg} \\
\text { Treating } 1-3 \text { attacks }\end{array}$ & $\begin{array}{l}\text { The primary study endpoint was the between-treatment } \\
\text { comparison of the direction and average strength of preference } \\
\text { at the end of the study. Preference score averaged to frovatriptan } \\
3.1 \pm 1.3 \text { for vs to almotriptan } 3.4 \pm 1.3 \text { for ( } P=N S) ; 63 \% \\
\text { of patients expressed a clear preference for a triptan }(29 \% \text { for } \\
\text { frovatriptan and } 34 \% \text { for almotriptan, } p=N S) \text {. } \\
\text { Pain free at } 2 \text { hours post dose - frovatriptan } 30 \% \text { and almotriptan } \\
32 \% \\
\text { Pain relief at } 2 \text { h post dose - frovatriptan - } 54 \% \text { and almotriptan } \\
-56 \%\end{array}$ \\
\hline Bigal et al. ${ }^{8}$ & $\begin{array}{l}\text { Adults - Placebo } \\
M O=29.3 \text { years } \\
\text { Dipyrone } M O=32.4 \text { years } \\
\text { Placebo } M A=28.2 \text { years } \\
\text { Dipyrone } M A=35.5 \text { years } \\
n=134 \text { ( } 38 \text { male; } 96 \text { female) }\end{array}$ & $\begin{array}{l}\text { Dypirone - intravenous injection } \\
\text { of } 1 \mathrm{~g} \text { dipyrone, diluted to } 10 \\
\mathrm{~mL} \text { of } 0.9 \% \text { physiological saline } \\
\text { Placebo - intravenous injection of } \\
10 \mathrm{~mL} 0.9 \% \text { physiological saline }\end{array}$ & 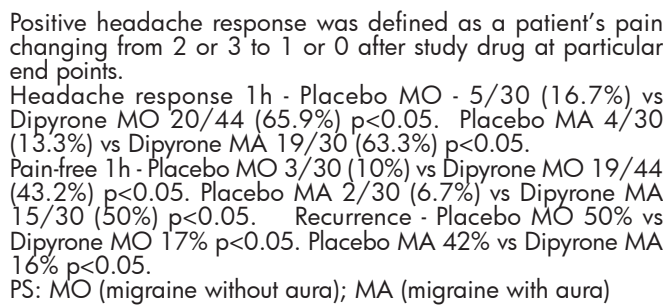 \\
\hline $\begin{array}{l}\text { Bigal, Bordini, } \\
\text { Speciali }^{38}\end{array}$ & $\begin{array}{l}\text { Adults - Placebo } 37.6 \text { years; } \\
\text { dipyrone: } 44.2 \text { years; } \\
\mathrm{n}=60 \text { ( } 31 \text { women and } 29 \text { men) }\end{array}$ & $\begin{array}{l}\text { Dipyrone } 1 \mathrm{~g} \text { in } 10 \mathrm{ml} \text { saline. } \\
\text { Placebo (intravenous injection of } \\
10 \mathrm{ml} \text { saline) }\end{array}$ & $\begin{array}{l}\text { Patients receiving dipyrone showed a statistically significant } \\
\text { improvement }(p<0.05 \text { ) of pain compared to placebo up to } 30 \\
\text { min after drug administration. The therapeutic gain was } 30 \% \text { in } \\
30 \text { min and } 40 \% \text { in } 60 \text { min. The number of patients needed to } \\
\text { be treated for at least one to have benefit was } 3.3 \text { in } 30 \text { min } \\
\text { and } 2.2 \text { in } 60 \text { min. There were statistically significant reductions } \\
\text { in the recurrence (dipyrone }=25 \% \text {, placebo }=50 \% \text { ) and use of } \\
\text { rescue medication (dipyrone }=20 \% \text {, placebo }=47.6 \% \text { ) for the } \\
\text { dipyrone group. }\end{array}$ \\
\hline Bigal et al. ${ }^{37}$ & $\begin{array}{l}\text { Adults - } 18 \text { to } 55 \text { years } \\
n=35 \text { (all female) }\end{array}$ & $\begin{array}{l}\text { Rizatriptan } 10 \mathrm{mg} \mathrm{+} \\
\text { dexamethasone } 4 \mathrm{mg} \\
\text { Rizatriptan } 10 \mathrm{mg} \\
\text { Dexamethasone } 4 \mathrm{mg} \\
\text { Tablets for 6-attack crossover } \\
\text { study. } \\
\text { Rizatriptan (RI) and } \\
\text { Dexamethasone (DE) }\end{array}$ & 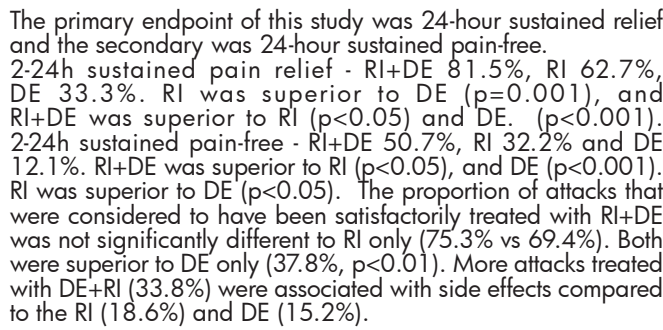 \\
\hline Bigal et al. ${ }^{67}$ & $\begin{array}{l}\text { Adults - Nausea at Baseline: } \\
40.6 \pm 11.7 \text { years; No Nausea } \\
\text { at Baseline: } 41.1 \pm 10.3 \text { years. } \\
n=454 \text { ( } 386 \text { female and } 68 \\
\text { male) }\end{array}$ & $\begin{array}{l}\text { Sumatriptan TDS } 6.5 \mathrm{mg} \\
\text { (iontophoretic transdermal } \\
\text { system) } \\
\text { Placebo TDS } \\
\text { over a } 4 \text {-hour period treating } \\
\text { one migraine attack. }\end{array}$ & $\begin{array}{l}\text { A total of } 130 \text { participants free of nausea at baseline were } \\
\text { treated with sumatriptan iontophoretic transdermal system (TDS), } \\
\text { while } 109 \text { participants free of nausea at baseline were treated } \\
\text { with placebo TDS. The occurrence of TEN (treatment-emergent } \\
\text { nausea) (over } 24 \text { hours post-treatment was significantly lower } \\
\text { with the sumatriptan TDS than with placebo ( } p=0.0011) \text {. These } \\
\text { differences were statistically significant at } 1 \text { hour }(13.8 \% \text { vs } 9.2 \% \text {, } \\
p<0.01), 2 \text { hours ( } 13.8 \% \text { vs } 4.6 \% p<0.001 \text { ) and } 3 \text { hours ( } 13.8 \% \\
\text { vs } 8.5 \%, p<0.01 \text { ). The efficacy of sumatriptan TDS was similar } \\
\text { regardless of the presence or absence of nausea at baseline for } \\
\text { all clinical parameters. }\end{array}$ \\
\hline
\end{tabular}




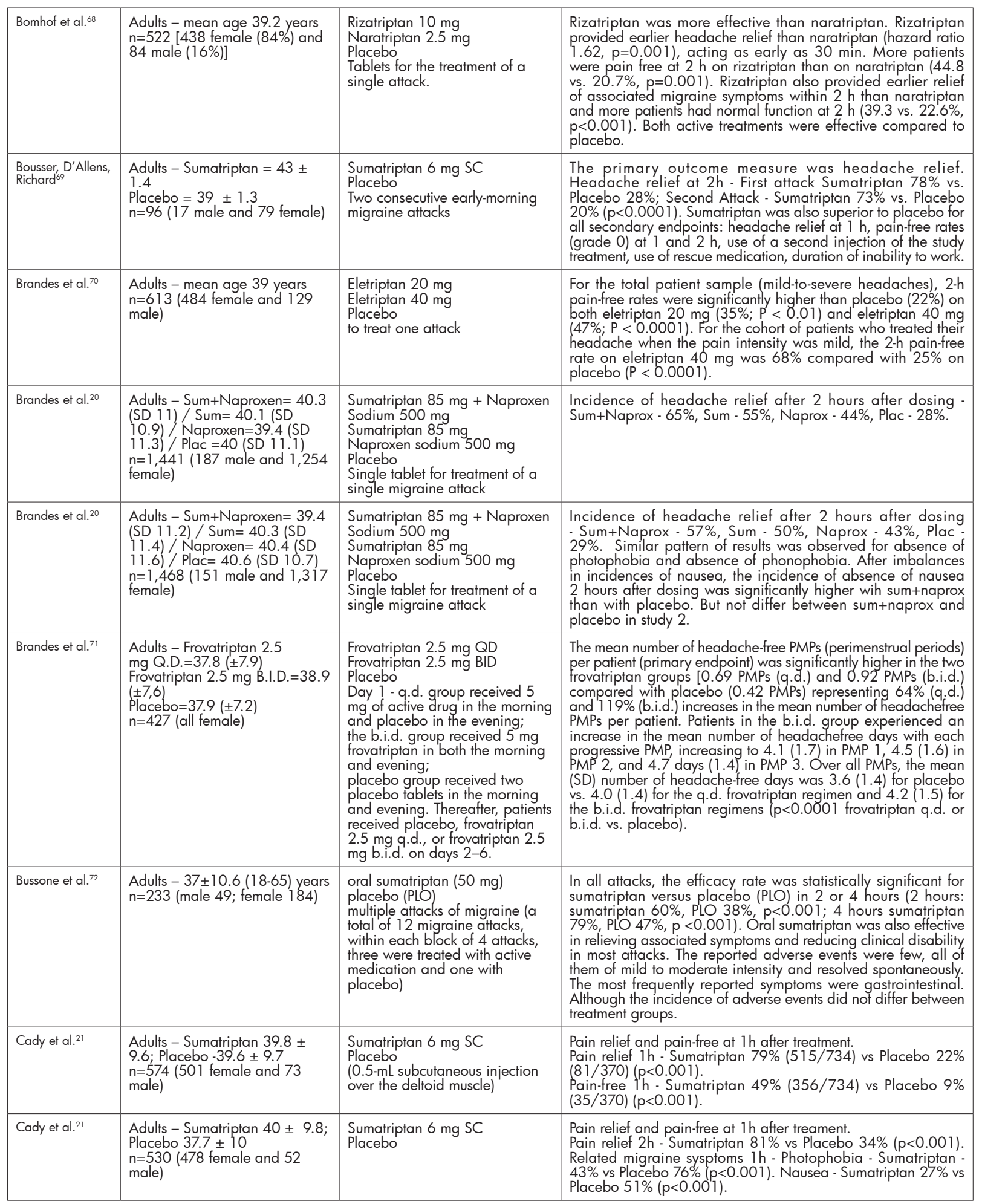




\begin{tabular}{|c|c|c|c|}
\hline Cady et al. ${ }^{73}$ & $\begin{array}{l}\text { Adults - mean age } 41.2 \text { and } \\
\text { (range } 18-76 \text { years) } \\
n=100 \text { (male } 9 \text { and female 91) }\end{array}$ & $\begin{array}{l}\text { Sumatriptan } 6 \text { mg sc, } \\
\text { Placebo } \\
\text { Four headaches of moderate or } \\
\text { severe intensity (grade } 2 \text { or } 3 \text { ) } \\
\text { were treated in the clinic with } \\
\text { a single dose of either } 6 \text { mg } \\
\text { SC sumatriptan (three attacks) } \\
\text { or placebo (one attack) in the } \\
\text { upper arm or thigh }\end{array}$ & $\begin{array}{l}\text { Sumatriptan statistically outperformed placebo on all efficacy } \\
\text { measures, including pain severity; presence/absence of nausea, } \\
\text { vomiting, phonophobia, and photophobia; rescue medication } \\
\text { use; and clinical disability. Efficacy was consistently maintained } \\
\text { with repeated administration. For all attacks, pain relief } 90 \\
\text { minutes postdose occurred in } 86 \% \text { to } 90 \% \text { of sumatriptan-treated } \\
\text { patients, compared with } 9 \% \text { to } 38 \% \text { of placebo-treated patients }\end{array}$ \\
\hline Cady et al. ${ }^{74}$ & $\begin{array}{l}\text { Adults - mean: } 41.5 \text { years } \\
\text { [frovatriptan-placebo: } 40.4 \\
\text { years; placebo-frovatriptan: } \\
42.5 \text { years; ] } \\
n=275 \text { ( } 36 \text { males and } 239 \\
\text { females) }\end{array}$ & $\begin{array}{l}\text { Oral frovatriptan } 2.5 \mathrm{mg} \\
\text { Placebo } \\
\text { The patients could take up to } \\
\text { two doses of study medication } \\
\text { per migraine attack. }\end{array}$ & $\begin{array}{l}\text { When patients received frovatriptan as the first dose, it was more } \\
\text { effective than placebo in terms of the proportion of patients who } \\
\text { were pain free at } 2 \mathrm{~h}(28 \% \text { vs } 20 \%, \mathrm{p}=0.04) \text {. This benefit was } \\
\text { sustained up to } 4 \mathrm{~h} \text { post-dose ( } \mathrm{p}=0.003) \text {. Early use of frovatriptan } \\
\text { significantly reduced re-medication }(\mathrm{p}<0.001) \text {. Twenty-four-hour } \\
\text { headache recurrence was low in both early }(4 \%) \text { and later use } \\
(6 \%) \text { groups. Sustained pain-free response occurred in } 40 \% \text { of } \\
\text { frovatriptan early use patients compared with } 31 \% \text { of later use } \\
\text { patients }(\mathrm{p}<0.05) \text {. Early use prevented headache progression: } \\
69 \%-78 \% \text { had mild/no headache } 2-4 \mathrm{~h} \text { after dose } 1 \text { frovatriptan } \\
\text { compared with } 54 \%-63 \% \text { taking dose } 1 \text { placebo (p<0.001). Early } \\
\text { use reduced pain burden and functional disability (p } \leq 0.001) \text {. } \\
\text { More patients rated early use of frovatriptan as excellent or good } \\
\text { (57\% vs } 46 \%) \text {. }\end{array}$ \\
\hline Cady et al. ${ }^{75}$ & $\begin{array}{l}\text { Adults - Rizatriptan - 40y; } \\
\text { Placebo - } 42 \\
\mathrm{n}=207 \text { ( } 187 \text { female and } 20 \\
\text { male) }\end{array}$ & $\begin{array}{l}\text { Rizatriptan } 10 \mathrm{mg} \text { ODT (orally } \\
\text { disintegrating tablet) } \\
\text { placebo }\end{array}$ & $\begin{array}{l}\text { The percentage of participants reporting pain freedom at } 2 \\
\text { hours after taking study drug was significantly greater for } \\
\text { rizatriptan ODT ( } 66 \% \text { ) compared with placebo. The percentage of } \\
\text { participants reporting sustained pain freedom between } 2 \text { and } 24 \\
\text { hours post-dose also was significantly greater for rizatriptan ODT } \\
(52 \%) \text { compared with placebo. The proportion of participants } \\
\text { reporting } 2 \text {-hour pain freedom in the placebo groups was similar } \\
\text { regardless of education. }\end{array}$ \\
\hline Cady et al. ${ }^{74}$ & $\begin{array}{l}\text { Adults }-42.0(10.5) \text { years } \\
n=212 \text { (Male } 35 \text { and Female } \\
177 \text { ) }\end{array}$ & $\begin{array}{l}22 \text { mg AVP- } 825 \text { nasal spray (a } \\
\text { drug-device combination of low- } \\
\text { dose sumatriptan powder - } 22 \\
\text { mg loaded dose) } \\
\text { Placebo device }\end{array}$ & 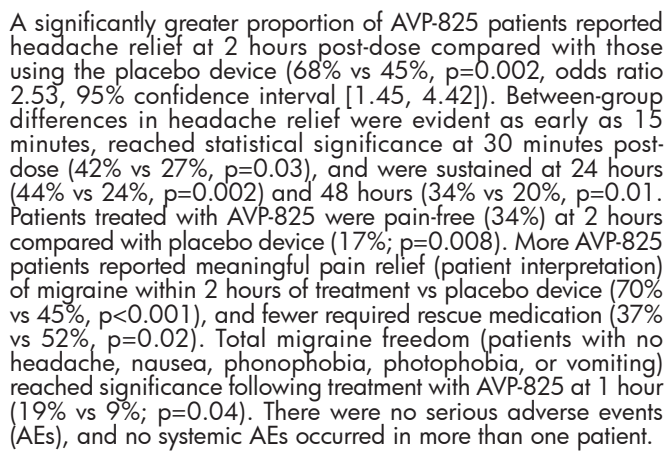 \\
\hline Cady et al. ${ }^{74}$ & $\begin{array}{l}\text { Adults - 39,8 (SD 10,4) (Range } \\
\text { from } 19 \text { to } 61 \text { years) } \\
n=20 \text { ( } 80 \% \text { female and } 20 \% \\
\text { male) }\end{array}$ & $\begin{array}{l}3 \mathrm{mg} \mathrm{SC} \text { sumatriptan } \\
6 \mathrm{mg} \text { SC sumatriptan } \\
\text { to treat } 1 \text { attack }\end{array}$ & $\begin{array}{l}\text { The primary efficacy endpoint was the proportion of } \\
\text { subjects reporting freedom from pain at } 60 \text { min postdose. } \\
\text { Pain-free } 60 \text { min postdose }-3 \mathrm{mg} S C \text { Sumatriptan- } 50 \% \text { vs } 52.6 \% \\
6 \text { mg SC Sumatriptan }(p=0.087) \text {. There was no difference in pain- } \\
\text { free between treatments in } 30,60,90 \text { and } 120 \text { min postdose. } \\
\text { Pain relief } 60 \text { minutes postdose }-3 \mathrm{mg} S C \text { Sumatriptan } 83.3 \% \text { vs } \\
6 \mathrm{mg} S \mathrm{~S} \text { Sumatriptan } 73.7 \%(p=0.48) \text {. As pain-free there were } \\
\text { no difference between treatments at } 30,90 \text { and } 120 \text { minutes } \\
\text { post dose. No difference also, in patients experienced relief } \\
\text { from nausea }(p=0.91) \text {, photophobia }(p=0.89) \text {, or phonophobia } \\
(p=0.88) \text {. }\end{array}$ \\
\hline Carpay et al. ${ }^{76}$ & $\begin{array}{l}\text { Adults - 18-65 years } \\
n=124 \text { (male } 23 \text { and female } \\
101)\end{array}$ & $\begin{array}{l}\text { Group A: sumatriptan } 0.5 \mathrm{ml} \text { of } \\
\text { the } 15 \mathrm{mg} / \mathrm{ml} \text { subcutaneous first } \\
\text { and oral sumatriptan } 100 \mathrm{mg} \\
\text { during the second period } \\
\text { Group B: the order was reversed }\end{array}$ & $\begin{array}{l}\text { Efficacy was evaluated } 2 \mathrm{~h} \text { after the administration of } \\
\text { subcutaneous and } 4 \mathrm{~h} \text { after the administration of oral sumatriptan. } \\
\text { Subcutaneous sumatriptan was significantly more effective than } \\
\text { oral sumatriptan in relieving headache (over all } 3 \text { attacks } 78 \% \\
\text { vs } 61 \% \text { improvement), improving clinical disability (55\% vs } 41 \% \\
\text { improvement) and relieving nausea ( } 69 \% \text { vs } 53 \% \text { ), vomiting }(72 \% \\
\text { vs } 32 \% \text { ) and phono or photophobia ( } 67 \% \text { vs } 49 \%) \text {. Median time } \\
\text { to recurrence was shorter after subcutaneous ( } 12.5 \mathrm{~h} \text { ) than after } \\
\text { oral sumatriptan ( } 18 \mathrm{~h}) \text {; the number of patients experiencing a } \\
\text { recurrence was similar. Patients reported more adverse events } \\
\text { after subcutaneous sumatriptan ( } 1.32 \text { per attack) than after the } \\
\text { oral form ( } 0.85 \text { per attack), but all adverse events were mild to } \\
\text { moderate in intensity and of short duration. }\end{array}$ \\
\hline Carpay et al. ${ }^{77}$ & $\begin{array}{l}\text { Adults - Sumatriptan } 50 \\
\text { mg tablet }=41.5 \text { (SD 11.9) } \\
\text { Sumatriptan } 100 \mathrm{mg} \\
\text { tablet }=39.7 \text { (SD } 10.9 \text { ) } \\
\text { Placebo }=40.6 \text { (SD 10.3) } \\
\mathrm{n}=432 \text { (358 female and } 74 \\
\text { male) }\end{array}$ & $\begin{array}{l}\text { Sumatriptan } 100 \mathrm{mg} \text { and } 50 \\
\text { mg tablets } \\
\text { Placebo } \\
\text { single migraine attack }\end{array}$ & $\begin{array}{l}\text { Sumatriptan tablets } 50 \mathrm{mg} \text { and } 100 \mathrm{mg} \text { were significantly more } \\
\text { effective than placebo in conferring freedom from pain } 2 \text { hours } \\
\text { after dosing (primary end point). In the intent-to-treat population, } \\
66.2 \% \text { of patients who received sumatriptan } 100 \mathrm{mg} \text { and } 51.1 \% \\
\text { of patients who received sumatriptan } 50 \mathrm{mg} \text { were pain free } 2 \\
\text { hours after dosing, compared with } 19.6 \% \text { of those who received } \\
\text { placebo. }\end{array}$ \\
\hline
\end{tabular}




\begin{tabular}{|c|c|c|c|}
\hline $\begin{array}{l}\text { Charlesworth } \\
\text { et al. }{ }^{78}\end{array}$ & $\begin{array}{l}\text { Adults - Men and women } \\
18-65 \text { years. } \\
n=1458 \text { (female } 1343 \text { and } \\
\text { male } 115 \text { ) }\end{array}$ & $\begin{array}{l}\text { Zolmitriptan nasal spray }(5.0, \\
2.5,1.0,0.5 \mathrm{mg}) \text {, } \\
\text { Zolmitriptan oral tablets } 2.5 \mathrm{mg} \\
\text { Placebo } \\
\text { treatment of three separate } \\
\text { moderate or severe migraine } \\
\text { headaches }\end{array}$ & $\begin{array}{l}\text { Each dose of zolmitriptan nasal spray produced a greater } 2 \text {-hour } \\
\text { headache response rate than placebo (70.3\%, } 58.6 \%, 54.8 \% \\
\text { and } 41.5 \% \text { for zolmitriptan nasal spray } 5.0,2.5,1.0 \text { and } 0.5 \mathrm{mg} \text {, } \\
\text { compared with } 30.6 \% \text { for placebo [all p<0.001 vs placebo]). } \\
\text { The } 2 \text {-hour headache response rate for zolmitriptan nasal spray } \\
5.0 \mathrm{mg} \text { was significantly higher than that of the zolmitriptan } \\
2.5 \mathrm{mg} \text { oral tablet (61.3\%; } \mathrm{p}<0.05 \text { ), while comparisons of nasal } \\
\text { spray } 0.5,1.0 \text { and } 2.5 \mathrm{mg} \text { with zolmitriptan } 2.5 \mathrm{mg} \text { oral tablet } \\
\text { were not statistically signiticant. The nasal spray } 5.0 \text { and } 2.5 \\
\text { mg showed a rapid onset of action, with a significant difference } \\
\text { in headache response compared with placebo from } 15 \text { minutes } \\
\text { through } 4 \text { hours after administration and a significant difference } \\
\text { between the nasal spray } 5.0 \text { mg and } 2.5 \text { mg oral tablet from } 15 \\
\text { minutes through to } 2 \text { hours (the other nasal spray doses were } \\
\text { not statistically significant compared with } 2.5 \text { mg oral tablet). } \\
\text { Zolmitriptan nasal spray resulted in pain-free rates that were } \\
\text { dose dependent. While all doses from } 1.0 \text { mg upwards produced } \\
\text { significant pain-free outcomes from } 30 \text { minutes versus placebo, } \\
\text { only the } 5.0 \text { mg dose produced pain-free rates significantly } \\
\text { superior to both placebo and the } 2.5 \text { mg oral tablet }\end{array}$ \\
\hline Colman et al. ${ }^{80}$ & $\begin{array}{l}\text { Adults - Almotriptan: } \\
41.25 \pm 10.09 \text { ( } 18 \text { to } 71 \text { ) years; } \\
\text { Sumatriptan: } 40.26 \pm 10.08 \\
\text { (18-65) years. } \\
\mathrm{n}=1,173 \text { (1044 female and } \\
129 \text { male) }\end{array}$ & $\begin{array}{l}\text { Almotriptan } 12.5 \mathrm{mg} \text { capsule } \\
\text { Sumatriptan } 50 \mathrm{mg} \text { capsule } \\
\text { The first dose of study } \\
\text { medication was taken at the } \\
\text { onset of a moderate or severe } \\
\text { migraine. The second dose was } \\
\text { taking if patient experienced } \\
\text { a relapse (an increase in pain } \\
\text { severity to moderate or severe } \\
\text { within } 24 \text { hours after the initial } \\
\text { dose, for those responding to } \\
\text { the initial dose) }\end{array}$ & $\begin{array}{l}\text { A total of } 1,173 \text { patients were treated with almotriptan or } \\
\text { sumatriptan. There were no significant differences between the } 2 \\
\text { treatment groups in terms of satisfaction with pain relief; however, } \\
\text { patients in the almotriptan group were significantly more satisfied } \\
\text { (less bothered) with side effects than those receiving sumatriptan } \\
(p=0.016) \text {. }\end{array}$ \\
\hline $\begin{array}{l}\text { Cull, Price, } \\
\text { Dunbar }^{82}\end{array}$ & $\begin{array}{l}\text { Adults - Group A - } 41 \pm 10.8 \\
\text { Group } B-40.5 \pm 10.3 \text { years. } \\
n=881 \text { ( } 155 \text { male } 726 \text { female) }\end{array}$ & $\begin{array}{l}\text { Dose } 1 \text { - Sumatriptan } 6 \mathrm{mg} \mathrm{sc} \\
\text { - both group at the onset of a } \\
\text { migraine headache of moderate } \\
\text { or severe intensity } \\
\text { Dose } 2 \text { (headache recurrence } \\
\text { only): } \\
\text { Group A Sumatriptan } 6 \mathrm{mg} \mathrm{SC} \\
\text { Goup B Placebo }\end{array}$ & $\begin{array}{l}\text { At each attack, } 6 \mathrm{mg} \text { sumatriptan given subcutaneously was } \\
\text { significantly }(\mathrm{p}<0.0005) \text { more effective than placebo at relieving } \\
\text { recurrent headache after one hour; } 83 \% \text { of patients reported } \\
\text { headache relief one hour after the initial dose of sumatriptan. } \\
\text { Sumatriptan was generally well tolerated. }\end{array}$ \\
\hline $\begin{array}{l}\text { Dahlöf, Edwards, } \\
\text { Tolth }^{83}\end{array}$ & $\begin{array}{l}\text { Adults }-45 \pm 11 \text { years } \\
n=27 \text { ( } 22 \text { female } 5 \text { male) }\end{array}$ & $\begin{array}{l}\text { Sumatriptan SC } 8 \mathrm{mg} \\
\text { Placebo (saline) } \\
0.5 \mathrm{ml} \\
\text { One migraine attack }\end{array}$ & $\begin{array}{l}\text { Primary outcome measure was the number of patients who } \\
\text { obtained complete or almost complete headache relief } \\
\text { within } 30,60,90,120 \text { min of taking study medication. } \\
\text { Headache relief at } 60 \text { min - Sumatriptan } 84 \% \text { vs Placebo } 11 \% \\
\text { (p<0.001); } 90 \text { min - Sumatriptan } 73 \% \text { vs Placebo } 7 \% \text { ( } p< \\
0.001) ; 120 \text { min } \\
\text { Sumatriptan } 63 \% \text { vs Placebo } 0 \text {. } \\
\text { Sumatriptan was significantly more effective than placebo in } \\
\text { relieving nausea and photophobia. Before treatment } 95 \% \text { of } \\
\text { patients had this symptom. After } 120 \text { minutes - Sumatriptan - } \\
16 \% \text { vs Placebo } 79 \% \text {. } \\
\text { Rescue medication at } 120 \text { min - taken by } 89 \% \text { from placebo vs } \\
11 \% \text { from sumatriptan group }(p<0.001) \text {. }\end{array}$ \\
\hline Dasbach et al. ${ }^{84}$ & $\begin{array}{l}\text { Adults - mean age } 40,6 \text { years } \\
n=407 \text { ( } 84 \% \text { female and } 66 \\
16 \% \text { male) }\end{array}$ & $\begin{array}{l}\text { Rizatriptan } 10 \mathrm{mg} \\
\text { Placebo } \\
3 \text { migraine attacks with } \\
\text { rizatriptan and } 1 \text { with placebo }\end{array}$ & $\begin{array}{l}\text { Hours of work loss due to absenteeism - Placebo - } 2.2 \mathrm{~h} / \\
\text { Rizatriptan - } 0.7 \mathrm{~h} \text {. } \\
\text { Period working with symptoms - Placebo - } 4,7 \mathrm{~h} / \text { Rizatriptan - } 4,2 \mathrm{~h} \\
\text { Effectiveness on the job - Patients taking rizatriptan was } 4,5 \% \\
\text { greater in comparison with placebo. Rizatriptan decreased the } \\
\text { total number of hours of work loss by } 1.1 \mathrm{~h} \text { per migraine attack } \\
\text { treated compared with placebo. }\end{array}$ \\
\hline
\end{tabular}




\begin{tabular}{|c|c|c|c|}
\hline Diamond et al. ${ }^{85}$ & $\begin{array}{l}\text { Adults - mean of } 40 \text { years of } \\
\text { age. } \\
n=1086 \text { ( } 956 \text { females and } 130 \\
\text { males) }\end{array}$ & $\begin{array}{l}\text { Sumatriptan nasal spray }(5,10, \\
\text { or } 20 \mathrm{mg}) \\
\text { Placebo } \\
\text { up to } 3 \text { migraine attacks. } \\
\text { Administered via a } 1 \text {-shot nasal } \\
\text { applicator into either nostril }\end{array}$ & $\begin{array}{l}\text { Across attacks, headache relief in the } 20,10 \text {, and } 5 \mathrm{mg} \text { drug } \\
\text { and placebo groups was experienced } 120 \text { minutes postdose by } \\
60 \%, 54 \%, 44 \% \text {, and } 32 \% \text { of patients, respectively ( } \mathrm{p}<0.05 \text { for } \\
\text { each sumatriptan nasal spray group vs placebo, for the } 10-\mathrm{mg} \\
\text { vs } 5 \text {-mg drug group, and for the } 20-\mathrm{mg} \text { vs } 5 \text {-mg drug group). } \\
\text { Two thirds of the } 20 \mathrm{mg} \text { patients treating } 3 \text { attacks experienced } \\
\text { relief at } 2 \text { hours postdose for at least } 2 \text { of } 3 \text { attacks. Clinical } \\
\text { disability scores at } 120 \text { minutes in the } 20,10 \text {, and } 5 \mathrm{mg} \text { drug and } \\
\text { placebo groups reflected no or mild impairment in } 70 \%, 67 \% \text {, } \\
57 \% \text {, and } 50 \% \text { of patients, respectively (p<0.05 for the } 10 \text { or } \\
20 \text { mg drug group vs placebo group, and for the } 20 \text {-mg vs } 5-\mathrm{mg} \\
\text { drug group). Similar efficacy rates were observed for nausea, } \\
\text { photophobia, and phonophobia. The incidence of adverse events } \\
\text { was not dose related. The most frequently reported adverse event } \\
\text { in the active treatment groups was taste disturbance (bad, bitter, } \\
\text { or unpleasant). }\end{array}$ \\
\hline Dib et al. ${ }^{86}$ & $\begin{array}{l}\text { Adults }-38.1 \pm 11.4 \text { years } \\
\mathrm{n}=235 \text { (female } 83.4 \% \text { female } \\
\text { and } 16.6 \% \text { male) }\end{array}$ & $\begin{array}{l}\text { Ketoprofen } 75 \mathrm{mg} \text {; Ketoprofen } \\
150 \mathrm{mg} \text {; Zolmitriptan } 2.5 \mathrm{mg} \\
\text { Placebo; (comparisons between } \\
\text { all treatments) } \\
\text { four consecutive attacks with } \\
\text { severe or moderate headache } \\
\text { Each treatment was enclosed in } \\
\text { opaque soft gelatin capsules }\end{array}$ & $\begin{array}{l}\text { Results are based on } 838 \text { attacks with a severe or moderate } \\
\text { headache that were evaluable at } 2 \text { hours. Relief was reported for } \\
62.6 \% \text { of headaches treated with ketoprofen } 75 \mathrm{mg}, 61.6 \% \text { with } \\
\text { ketoprofen } 150 \mathrm{mg} \text {, and } 66.8 \% \text { with zolmitriptan. The difference } \\
\text { between the three active treatments and placebo ( } 27.8 \% \text { relief) } \\
\text { was highly significant. Headaches at } 2 \text { hours disappeared more } \\
\text { frequently for the active treatments than for placebo. }\end{array}$ \\
\hline Diener $^{87}$ & $\begin{array}{l}\text { Adults }- \text { L-ASA }=41.5 y \text { (SD: } \\
11.8) ; \text { Sumatriptan }=40.9 y \\
(S D 11) ; \text { Placebo }=39,8 y(S D \\
11.7) \text { (55 male and } 221 \text { female) }\end{array}$ & $\begin{array}{l}\text { Lysine acetylsacicylate iv } 1.8 \mathrm{~g} \\
\text { Sumatriptan sc } 6 \mathrm{mg} \\
\text { Placebo } \\
\text { One administration }\end{array}$ & $\begin{array}{l}\text { The main result of this study was the significant difference } \\
(\mathrm{p}=0.001) \text { in efficacy, expressed as headache relief from grade } 3 \\
\text { or } 2 \text { to grade } 1 \text { or } 0 \text {, within } 2 \text { hours after administration of } L-A S A \\
\text { and sumatriptan compared to placebo. Placebo was significantly } \\
\text { inferior to both verum drugs ( } p<0.0001) \text {. Sumatriptan achieves } \\
\text { a higher rate of headache-free patients after } 2 h \text {, however was } \\
\text { associated with a significantly higher incidence of adverse events. }\end{array}$ \\
\hline Diener et al. ${ }^{88}$ & $\begin{array}{l}\text { Adults - ranged from } 18 \text { to } 64 \\
\text { years (median age } 41 \text { years) } \\
n=924 \text { ( } 781 \text { females and } 143 \\
\text { males) }\end{array}$ & $\begin{array}{l}\text { Alniditan ( } 1.4 \mathrm{mg} \text { and } 1.8 \\
\mathrm{mg} \text { ) sc } \\
\text { Sumatriptan }(6 \mathrm{mg}) \mathrm{sc} \\
\text { Placebo } \\
\text { one single treatment. }\end{array}$ & $\begin{array}{l}\text { The number of subjects who were pain free at } 2 \mathrm{~h} \text { (primary } \\
\text { endpoint) was: } 22(14.1 \%) \text { with placebo, } 174(56.3 \%) \text { with } \\
\text { alniditan } 1.4 \mathrm{mg}, 87(61.7 \%) \text { with alnditan } 1.8 \mathrm{mg} \text { and } \\
209(65.9 \%) \text { with sumatriptan } 6 \mathrm{mg} \text {. Alniditan } 1.4 \mathrm{mg} \text { was } \\
\text { significantly better ( } \mathrm{P}<0.001) \text { than placebo and sumatriptan } \\
\text { was significantly better }(\mathrm{P}=0.015) \text { than alniditan } 1.4 \mathrm{mg} \text {. The } \\
\text { number of responders (reduction of headache severity from } \\
\text { moderate or severe headache before treatment to mild or absent } \\
\text { at } 2 \mathrm{~h}) \text {, was } 59(37.8 \%) \text { on placebo, } 250(80.9 \%) \text { on alniditan } \\
1.4 \mathrm{mg}, 120(85.1 \%) \text { on alniditan } 1.8 \mathrm{mg} \text {, and } 276(87.1 \%) \text { on } \\
\text { sumatriptan. Recurrence rates were: } 22 \text { (37.3\%) with placebo, } \\
87(34.8 \%) \text { with alniditan } 1.4 \text { mg, } 35(29.2 \%) \text { with alniditan } 1.8 \\
\text { mgand } 108(39.1 \%) \text { with sumatriptan. Adverse events occurred } \\
\text { in } 577 / 924(62.4 \%) \text { subjects, } 39.5 \% \text { with placebo, } 69.3 \% \text { with } \\
\text { alniditan } 1.4 \mathrm{mg}, 64.5 \% \text { with alniditan } 1.8 \text { mg and } 66.2 \% \text { with } \\
\text { sumatriptan } 6 \mathrm{mg} \text {. }\end{array}$ \\
\hline Diener et al. ${ }^{89}$ & $\begin{array}{l}\text { Adults - Eletriptan } 80 \mathrm{mg}-40 \\
\pm 11 \text {; Eletriptan } 40 \mathrm{mg}-40 \pm \\
11 ; \text { Cafergot } 40 \pm 10 ; \text { Placebo } \\
42 \pm 11 \\
\mathrm{n}=733 \text { (640 female and } 93 \\
\text { male) }\end{array}$ & $\begin{array}{l}\text { Eletriptan } 80 \text { and } 40 \mathrm{mg} \\
\text { Cafergot (ergotamine tartrate } 2 \\
\text { mg, caffeine } 200 \mathrm{mg} \text { ) } \\
\text { Placebo tablets }\end{array}$ & $\begin{array}{l}\text { The primary efficacy endpoint was headache response } \\
\text { (improvement from severe or moderate to mild or no pain) at } \\
2 \mathrm{~h} \text { - Eletriptan } 80 \mathrm{mg} 68 \% \text {, Eletriptan } 40 \mathrm{mg} 54 \% \text {, Cafergot } \\
33 \% \text { and Placebo } 21 \% \text { ( } \mathrm{p}<0.01 \text { for all comparisons). } \\
\text { Secondary efficacy measures: pain-free rates at } 2 \mathrm{~h} \text { - Eletriptan } \\
80 \mathrm{mg} 38 \% \text {, eletriptan } 40 \mathrm{mg} 28 \% \text {, Cafergot - } 10 \% \text {, Placebo- } 5 \% \text {. }\end{array}$ \\
\hline Diener et al. ${ }^{30}$ & $\begin{array}{l}\text { Adults - Acetylsalicylic } \\
\text { acid } 38.8 \text {, Ibuprofen } 38.4 \text {, } \\
\text { Sumatriptan } 38.2 \text { and Placebo } \\
38.3 \text { years. } \\
n=313\end{array}$ & $\begin{array}{l}\text { effervescent acetylsalicylic acid } \\
\text { (ASA) } 500 \mathrm{mg} \\
\text { capsule lbuprofen } 400 \mathrm{mg} \\
\text { gelatin capsules containing } \\
\text { sumatriptan tablets } 50 \mathrm{mg} \\
\text { Placebo } \\
\text { Single dose }\end{array}$ & $\begin{array}{l}\text { The percentage of patients with reduction in headache severity } \\
\text { from moderate or severe to mild or no pain (primary endpoint) } \\
\text { was } 52.5 \% \text { for ASA, } 60.2 \% \text { for ibuprofen, } 55.8 \% \text { for sumatriptan } \\
\text { and } 30.6 \% \text { for placebo. All active treatments were superior } \\
\text { to placebo (P<0.000 } 1 \text { ), whereas active treatments were not } \\
\text { statistically different. The number of patients pain-free at } 2 \mathrm{~h} \text { was } \\
27.1 \%, 33.2 \%, 37.1 \% \text { and } 12.6 \% \text { for those treated with ASA, } \\
\text { ibuprofen, sumatriptan or placebo, respectively. The difference } \\
\text { between ASA and sumatriptan was statistically significant } \\
(p=0.025) \text {. }\end{array}$ \\
\hline Diener $^{90}$ & $\begin{array}{l}\text { Adults - Almotriptan 12.5mg } \\
-41.1 \text { (SD 11.4); Placebo - } \\
41.4 \text { (SD 12) years } \\
\mathrm{n}=221(192 \text { female and } 29 \\
\text { male) }\end{array}$ & $\begin{array}{l}\text { Almotriptan } 12,5 \mathrm{mg} \\
\text { Placebo } \\
\text { tablets }\end{array}$ & $\begin{array}{l}\text { Efficacy measure was pain relief at } 2 \mathrm{~h} \text { after administration } \\
\text { of study medication. An additional endpoint assessed here is } \\
\text { complete relief. } \\
\text { Pain relief } 2 \mathrm{~h} \text { for patients with a severe baseline pain intensity - } \\
\text { Almotriptan } 46,4 \% \text { vs Placebo - } 25 \%(\mathrm{p}<0.05) \text {. } \\
\text { Pain relief } 2 \mathrm{~h} \text { for patients with a moderate baseline pain intensity } \\
\text { - Almotriptan } 50 \% \text { vs Placebo } 15 \%(p<0.05) \text {. } \\
\text { Complete pain relief } 2 \mathrm{~h} \text { - Almotriptan } 17,1 \% \text { vs Placebo } 4,4 \% \text {; } \\
(\mathrm{p}<0.05) \text {. }\end{array}$ \\
\hline
\end{tabular}




\begin{tabular}{|c|c|c|c|}
\hline Diener et al. ${ }^{91}$ & $\begin{array}{l}\text { Adults - sumatriptan: } 41.1 \\
(14.2), \text { Almotriptan } 41.1 \\
(11.4), \text { placebo } 41.4 \text { (12.0) } \\
n=221 \text { (male } 29 \text { and female } \\
192)\end{array}$ & $\begin{array}{l}\text { Almotriptan } 12.5 \mathrm{mg} \\
\text { Placebo } \\
\text { Tablets }\end{array}$ & $\begin{array}{l}\text { In the first attack, } 221 \text { of } 302 \text { participants }(73 \%) \text { did not achieve } \\
2 \text {-hour pain relief with sumatriptan and were randomized to } \\
\text { treatment of their second attack with almotriptan } 12.5 \text { mg or } \\
\text { placebo. Of the } 198 \text { sumatriptan nonresponders who treated } \\
\text { their second attack ( } 99 \text { almotriptan; } 99 \text { placebo), } 70 \% \text { had } \\
\text { severe headache pain at baseline. Two-hour pain-relief rates } \\
\text { were significantly higher with almotriptan compared to placebo } \\
\text { (47.5\% vs } 23.2 \% ; \text { p }<0.001) \text {. A significant treatment effect for } \\
\text { almotriptan was also seen in pain-tree rates at } 2 \text { hours }(33.3 \% \\
\text { vs } 14.1 \% ; \mathrm{P}<.005) \text { and sustained freedom from pain }(20.9 \% \\
\text { vs } 9.0 \% ; \mathrm{p}<0.05) \text {. In the second attack, } 7.1 \% \text { of patients in the } \\
\text { almotriptan group experienced adverse events compared to } 5.1 \% \\
\text { in the placebo group }(P=.77) \text {. }\end{array}$ \\
\hline $\begin{array}{l}\text { Díez, Straube, } \\
\text { Zanchin }\end{array}$ & $\begin{array}{l}\text { Adults }-36.3(10.4) \text { years } \\
n=372 \text { (Female: } 319 \text { and Male: } \\
53 \text { ) }\end{array}$ & $\begin{array}{l}\text { Rizatriptan } 10 \mathrm{mg} \text { followed by } \\
\text { almotriptan } 12.5 \mathrm{mg} \text {, } \\
\text { and } \\
\text { reverse sequence } \\
\text { tablets for the acute treatment of } \\
\text { two migraine attacks }\end{array}$ & $\begin{array}{l}\text { Almotriptan was preferred by } 55 \% \text { of patients but the difference } \\
\text { was not statistically significant. Efficacy was the principal } \\
\text { determinant of patient preference for one or the other triptan, but a } \\
\text { significantly greater proportion of patients preferring almotriptan } \\
\text { did so because they experienced fewer AEs associated with } \\
\text { treatment. The two treatments were of comparable efficacy in } \\
\text { measures of pain relief ( } 74 \% \text { versus } 76 \% \text {, almotriptan versus } \\
\text { rizatriptan) and both treatments were safe and well tolerated }\end{array}$ \\
\hline $\begin{array}{l}\text { Diupesland, } \\
\text { Docekal }^{93}\end{array}$ & $\begin{array}{l}\text { Adults }-42 \text { years [sumatriptan } \\
10 \mathrm{mg}-40.6(21.0-59.0) \\
\text { years; sumatriptan } 20 \mathrm{mg} \\
-42.7 \text { (18.0-58.0) years; } \\
\text { placebo - } 42.8(21.0-64.0) \\
\text { years;] } \\
\mathrm{n}=117 \text { ( } 100 \text { females and } 17 \\
\text { males) }\end{array}$ & $\begin{array}{l}\text { Sumatriptan } 10 \mathrm{mg} \text { or } 20 \mathrm{mg} \\
\text { Placebo } \\
\text { single treatment day } \\
\text { Nose powdered drug device } \\
\text { with nosepiece }\end{array}$ & $\begin{array}{l}\text { A greater proportion of subjects who received sumatriptan were } \\
\text { pain-free at } 120 \text { minutes compared with those who received } \\
\text { placebo }(10 \mathrm{mg} / 20 \mathrm{mg} \text { sumatriptan vs. placebo } 54 \% / 57 \% \text { vs. } \\
25 \% \text {, p }<0.05) \text {. Significant benefits were also observed for pain } \\
\text { relief at } 120 \text { minutes }(84 \% / 80 \% \text { vs. } 44 \%, P<0.001 / .01) \text { and } \\
\text { as early as } 60 \text { minutes }(73 \% / 74 \% \text { vs. } 38 \%, P<0.01) \text { and for } \\
48 \text { hours sustained pain-free }(P<0.05) \text {. Treatment-related adverse } \\
\text { events were rare, with a metallic taste being the most commonly } \\
\text { reported }(10 \% / 13 \%) \text {. }\end{array}$ \\
\hline Dodick et al. ${ }^{94}$ & $\begin{array}{l}\text { Adults }- \text { Zolmitriptan } 5 \mathrm{mg} \text { nasal } \\
\text { spray }-40.7 \pm 10.4 \text { years; } \\
\text { Placebo }-40.7 \pm 10.3 \text { years } \\
\mathrm{n}=1868(1,620 \text { female and } \\
248 \text { male) }\end{array}$ & $\begin{array}{l}\text { Zolmitriptan } 5 \mathrm{mg} \text { nasal spray } \\
\text { Placebo } \\
\text { Treat up to two migraine attacks, } \\
\text { each with a single dose of study } \\
\text { medication }\end{array}$ & $\begin{array}{l}\text { The headache response rate at } 2 \text { hours post-dose was } 66.2 \% \text { for } \\
\text { the zolmitriptan group, compared with } 35.0 \% \text { for the placebo } \\
\text { group }(p<0.001) \text {. Zolmitriptan nasal spray also produced } \\
\text { significantly higher headache response rates than placebo at all } \\
\text { earlier timepoints assessed, starting as early as } 15 \text { minutes post- } \\
\text { dose }(p<0.001) \text {. Similar results were obtained for the analysis of } \\
\text { the first attack. Significantly higher pain-free rates were obtained } \\
\text { with zolmitriptan nasal spray, compared with placebo, from } \\
15 \text { minutes post-dose onward }(p<0.005) \text {. Zolmitriptan nasal } \\
\text { spray was also significantly superior to placebo for headache } \\
\text { response at } 4 \text { hours, sustained headache response at } 24 \text { hours } \\
\text { and sustained pain-free rate at } 24 \text { hours. Zolmitriptan nasal } \\
\text { spray was well tolerated, with most adverse events being of short } \\
\text { duration and mild or moderate intensity. }\end{array}$ \\
\hline Dowson et al. ${ }^{95}$ & $\begin{array}{l}\text { Adults range: } 17 \text { and } 66 \\
\text { years; Almotriptan } 12.5 \mathrm{mg} \\
-42.8 \pm 10.7 \text {; Almotriptan } 25 \\
\mathrm{mg}-41.4 \pm 11.0 ; \text { Sumatriptan } \\
100 \mathrm{mg}-42.0 \pm 10.5 ; \text { placebo - } \\
40.2 \pm 10.1 \text {; } \\
\mathrm{n}=668 \text { (101 male and } 567 \\
\text { female) }\end{array}$ & $\begin{array}{l}\text { Oral almotriptan ( } 12.5 \mathrm{mg} \text { and } \\
25 \mathrm{mg} \text { ) } \\
\text { Sumatriptan ( } 100 \mathrm{mg}) \\
\text { Placebo } \\
\text { single oral dose (capsules) }\end{array}$ & $\begin{array}{l}\text { The primary efficacy assessment was migraine pain relief, } \\
\text { improvement from severe or moderate pain to mild or no pain, } \\
\text { at } 2 \mathrm{~h} \text { after treatment. Response rates, stratified for variation in } \\
\text { baseline pain levels, for both almotriptan doses were equivalent to } \\
\text { sumatriptan and significantly better than placebo. Other efficacy } \\
\text { assessments confirmed the equivalence of the almotriptan groups } \\
\text { with the sumatriptan group. Almotriptan } 12.5 \mathrm{mg} \text { was as well } \\
\text { tolerated as placebo ( } \mathrm{P}=0.493 \text { ) and significantly better tolerated } \\
\text { than sumatriptan ( } \mathrm{P}<0.001) \text {, in terms of the overall incidence } \\
\text { of adverse } \\
\text { events. There was no statistically significant difference in the } \\
\text { incidence of adverse events between almotriptan } 25 \mathrm{mg} \text { and } \\
\text { sumatriptan } 100 \mathrm{mg}(\mathrm{P}=0.376) \text {. }\end{array}$ \\
\hline Dowson et al. ${ }^{96}$ & $\begin{array}{l}\text { Adults - Placebo: } 206 \text { female } \\
\text { and } 33 \text { male; } 204 \text { female and } \\
27 \text { male; } \\
\mathrm{n}=470 \text { ( } 410 \text { female and } 60 \\
\text { male) }\end{array}$ & $\begin{array}{l}\text { Zolmitriptan } 2.5 \mathrm{mg} \text { (orally } \\
\text { disintegrating tablets) } \\
\text { Placebo } \\
\text { Acute treatment of a single } \\
\text { moderate or severe migraine } \\
\text { headache }\end{array}$ & $\begin{array}{l}\text { Headache relief following zolmitriptan } 2.5 \mathrm{mg}(63 \%) \text { was } \\
\text { significantly greater than with placebo }(22 \% \text { at } 2 \mathrm{~h} \text { post- } \\
\text { dose (primary endpoint; } \mathrm{p}<0.0001) \text {. The zolmitriptan orally } \\
\text { disintegrating tablet was also significantly more effective } \\
\text { than placebo for } 1,2 \text { and } 4 \mathrm{~h} \text { pain-free response }(8 \% \text { vs. } \\
3 \%, \mathrm{P}=0.0207,27 \% \text { vs. } 7 \%, \mathrm{p}<0.0001 \text {, and } 37 \% \text { vs. } 11 \% \text {, } \\
\mathrm{p}<0.0001 \text {, respectively). Of those patients stating a preference, } \\
70 \% \text { of patients preferred the orally disintegrating tablet to a } \\
\text { conventional tablet. }\end{array}$ \\
\hline $\begin{array}{l}\text { Dowson, } \\
\text { Massiou, } \\
\text { Aurora }{ }^{97}\end{array}$ & $\begin{array}{l}\text { Adults - Group } 1-37 \text { (19-49); } \\
\text { Group } 2-40 \text { (19-50) } \\
n=115 \text { (female only) }\end{array}$ & $\begin{array}{l}\text { Sumatriptan } 100 \mathrm{mg} \text { oral } \\
\text { Placebo } \\
\text { Four menstrual periods. }\end{array}$ & $\begin{array}{l}\text { The primary study efficacy endpoints were the proportions of } \\
\text { patients who reported headache relief at } 4 \text { h post treatment. A } \\
\text { small number of patients had mentrually related migraine, but } \\
\text { efficacy analyses were conducted for the whole study sample. } \\
\text { Headache relief at } 4 \mathrm{~h} \text { - Patients inside menstrual window } \\
\text { Sumatriptan } 67 \% \text { vs Placebo } 33 \% \text { ( } p=0.0072 \text { ) Outside menstrual } \\
\text { window - Sumatriptan } 79 \% \text { vs Placebo } 31 \%(p=0.0001) \text {. } \\
\text { Complete headache relief at } 4 \mathrm{~h} \text { - Inside menstrual window - } \\
\text { Sumatriptan } 49 \% \text { vs Placebo - } 10 \%(p=0.0001) \text {. Outside } \\
\text { menstrual window - Sumatriptan } 60 \% \text { vs Placebo } 9 \%(p=0.0001)\end{array}$ \\
\hline
\end{tabular}




\begin{tabular}{|c|c|c|c|}
\hline Evers et al. ${ }^{48}$ & $\begin{array}{l}\text { Adolescents }-13.9 \pm 2.8 \text { years } \\
n=32(18 \text { female and } 14 \text { male) }\end{array}$ & $\begin{array}{l}\text { Oral zolmitriptan } 2.5 \mathrm{mg} \\
\text { lbuprofen } 200 \text { or } 400 \mathrm{mg} \\
\text { (according to child age) } \\
\text { Placebo } \\
\text { Three migraine attacks }\end{array}$ & $\begin{array}{l}\text { The number of patients with pain relief after } 2 \text { hours was chosen } \\
\text { as the primary outcome measure. } \\
\text { Pain relief } 2 \mathrm{~h} \text { - Zolmitriptan } 62 \% \text { vs Placebo - } 28 \%(\mathrm{p}<0.05) \text { and } \\
\text { lbuprofen } 69 \% \text { (in comparison with placebo } \mathrm{p}<0.05) \text {. } \\
\text { Pain free } 2 \mathrm{~h} \text { - Zolmitriptan } 45 \% \text { vs Placebo }-7 \%(\mathrm{p}<0,01 \text { ) } \\
\text { and Ibuprofen } 48 \% \text { (in comparison with placebo } \mathrm{p}<0.01) \text { ) } \\
\text { Sustained pain-free - Zolmitriptan } 34 \% \text { vs Placebo }-7 \%(\mathrm{p}<0.05 \text { ) } \\
\text { and lbuprofen } 38 \% \text { (in comparison with placebo } p<0.05)\end{array}$ \\
\hline Facchinetti et al. ${ }^{98}$ & $\begin{array}{l}\text { Adults - mean age } 37.5 \\
n=226 \text { (female only) }\end{array}$ & $\begin{array}{l}\text { Sumatriptan } 6 \mathrm{mg} \\
\text { Placebo } \\
\text { Pre-filled syringe in } \\
\text { subcutaneous injection }\end{array}$ & $\begin{array}{l}\text { The efficacy results were consistent for attacks one and two: } \\
2 \mathrm{~h} \text { after treatment in attacks one and two, } 53(73 \%) \text { and } 51 \\
\text { ( } 81 \% \text {; ) of the sumatriptan-treated subjects, respectively, reported } \\
\text { headache relief (reduction of a severe or moderately severe } \\
\text { headache to a mild or no headache), compared with } 27(31 \%) \\
\text { and } 18(29 \%) \text { of the placebo-treated subjects }(\mathrm{p}<0.001) \text {. Within } \\
24 \text { hours of treatment in attack one, } 28(53 \%) \text { and } 14(52 \%) \text { of } \\
\text { the initial responders to sumatriptan and placebo, respectively, } \\
\text { experienced headache recurrence. }\end{array}$ \\
\hline Färkkilä et al. ${ }^{99}$ & $\begin{array}{l}\text { Adults }- \text { Eletriptan } 80 \mathrm{mg}-40.9 \\
\pm 10.2 ; \text { Eletriptan } 40 \mathrm{mg}-41.4 \\
\pm 10.6 \text {; Placebo }-40.9 \pm 12 \\
\mathrm{n}=446 \text { (385 female and } 61 \\
\text { male) }\end{array}$ & $\begin{array}{l}\text { Eletriptan } 40 \text { (E40) and } 80 \mathrm{mg} \\
\text { (E80) } \\
\text { Placebo } \\
\text { Oral tablets }\end{array}$ & 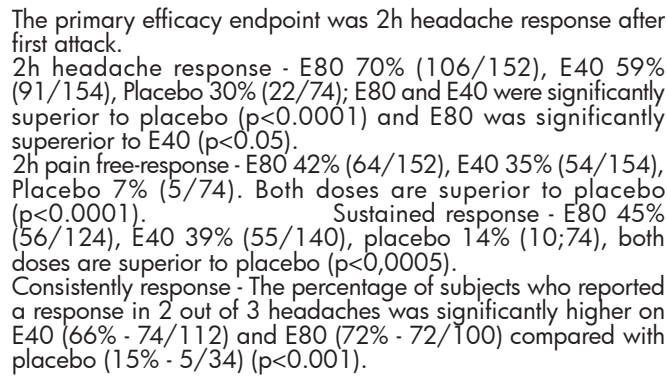 \\
\hline Fernandes et al. ${ }^{39}$ & $\begin{array}{l}\text { Adults - Dipyrone - male } 32.2 \\
\text { (DP 12.6) female } 34.3 \text { (DP } \\
9.6) ; \text { Metoclopramide - male } \\
29 \text { (DP 8.6) female } 35.8 \text { (DP } \\
6.4 \text { ) years. } \\
\text { n=27 ( } 14 \text { male and } 13 \text { female) }\end{array}$ & $\begin{array}{l}\text { Dipyrone IV } \\
\text { Metoclopramide IV } \\
\text { One migraine attack }\end{array}$ & $\begin{array}{l}\text { Among male patients, it was observed that the percentage } \\
\text { variation in pain scores before and after treatment was, in } \\
\text { general, greater in patients treated with metoclopramide than } \\
\text { in patients treated with dipyrone }(p=0.052) \text {. No difference was } \\
\text { seen between female patients }(p=0.748) \text {. }\end{array}$ \\
\hline Ferrari et al. ${ }^{100}$ & $\begin{array}{l}\text { Adults }- \text { Sum } 100 \mathrm{mg}+\text { Sum } 100 \\
\mathrm{mg}-40.5 \pm 10.5 \\
\text { Sum } 100 \mathrm{mg}+\text { Placebo }-40.5 \\
\pm 10.5 \\
\mathrm{n}=1246 \text { ( } 1021 \text { female and } \\
225 \text { male) }\end{array}$ & $\begin{array}{l}\text { Sumatriptan } 100 \mathrm{mg} \\
\text { Placebo } \\
\text { Tablets to treat up to three } \\
\text { migraine attacks }\end{array}$ & $\begin{array}{l}\text { The primary objective of the study was to compare headache } \\
\text { improvement from moderate or severe at time } 0 \text { to none or mild at } \\
4 \mathrm{~h} \text { on sumatriptan } 100 \mathrm{mg}+\text { sumatriptan } 100 \mathrm{mg} \text { and } 100 \mathrm{mg}+ \\
\text { placebo. } \\
\text { improvement }-2 \mathrm{~h} \text { after the first dose of } 100 \mathrm{mg} \text { sumatriptan }-56 \% \\
\text { Sum+Sum vs } 55 \% \text { Sum+Plac. } \\
\text { Headache improvement at } 4 \mathrm{~h}-77 \% \text { Sum+Sum vs } 80 \% \text { Sum+Plac. } \\
\text { Headache recurrence - } 25 \% \text { Sum+Plac vs } 22 \% \text { Sum+Sum }\end{array}$ \\
\hline Freitag et al. ${ }^{101}$ & $\begin{array}{l}\text { Adults - Isometheptene } \\
\text { Combination- } 40.9 \pm 9.6 \\
\text { Sumatriptan succinate }-43.3 \\
\pm 9.6 n=126 \text { ( } 112 \text { female and } \\
14 \text { male) }\end{array}$ & $\begin{array}{l}\text { Isometheptene Combination } \\
\text { ( } 65 \text { mg isometheptene, } 100 \mathrm{mg} \\
\text { dichloralphenazone, and } 325 \\
\text { mg acetaminophen) - } 5 \text { capsules } \\
\text { taken over several hours } \\
\text { Sumatriptan Succinate } 25 \mathrm{mg} \mathrm{(2} \\
\text { doses) capsules } \\
\text { Placebo } \\
\text { Single migraine attack }\end{array}$ & $\begin{array}{l}\text { Primary outcome: \% of patients with mild or no headache at } 2 \\
\text { hours and/or } 4 \text { hours after the first dose of study medication, } \\
\text { and \% of patients who did not suffer a recurrence of headache } \\
\text { within } 24 \text { hours of the initial dose. } \\
\text { No or mild headache at } 4 \text { hours - Isometheptene combination } \\
76 \% \text { vs Sumatriptan } 80 \% \text { (X2 }=0.22 \text { ). } \\
\text { Patients without headache or had only a mild migraine at } 24 \\
\text { hours - } 82 \% \text { in both groups. }\end{array}$ \\
\hline Freitag et al. ${ }^{102}$ & $\begin{array}{l}\text { Adults - Rizatriptan } 10 \mathrm{mg} \text { - } 40 \\
\text { years; Placebo }-41 \text { years } \\
\mathrm{n}=277 \text { ( } 249 \text { female and } 28 \\
\text { male) }\end{array}$ & $\begin{array}{l}\text { Rizatriptan } 10 \text { mg ODT } \\
\text { Placebo } \\
\text { Single migraine attack }\end{array}$ & $\begin{array}{l}\text { There was a greater percentage of patients with elimination of } \\
\text { nausea at } 2 \text { hours (primary efficacy endpoint) in the rizatriptan } \\
\text { ODT group compared with the placebo group }(70.3 \% \text { vs } 62.0 \%) \text {, } \\
P=0.165 \text {, odds ratio }(95 \% \mathrm{Cl})=1.45(0.86,2.46)-\text { not } \\
\text { statistically significant. } \\
\text { There was a significantly greater percentage of patients who } \\
\text { achieved 2-hour pain relief (secondary efficacy endpoint) with } \\
\text { rizatriptan ODT compared with placebo }(69.7 \% \text { vs } 54.3 \%), P= \\
.012 \text {, odds ratio }(95 \% \mathrm{Cl})=1.94(1.16,3.25) \text {. }\end{array}$ \\
\hline
\end{tabular}




\begin{tabular}{|c|c|c|c|}
\hline Freitag et al. ${ }^{103}$ & $\begin{array}{l}\text { Adults }-40.4(10.8) \\
n=315 \text { ( } 274 \text { female and } 41 \\
\text { male) }\end{array}$ & $\begin{array}{l}\text { Almotriptan } 12.5 \mathrm{mg} \\
\text { Placebo } \\
3 \text { consecutive migraine attacks } \\
\text { Pharmaceutical form not } \\
\text { informed }\end{array}$ & 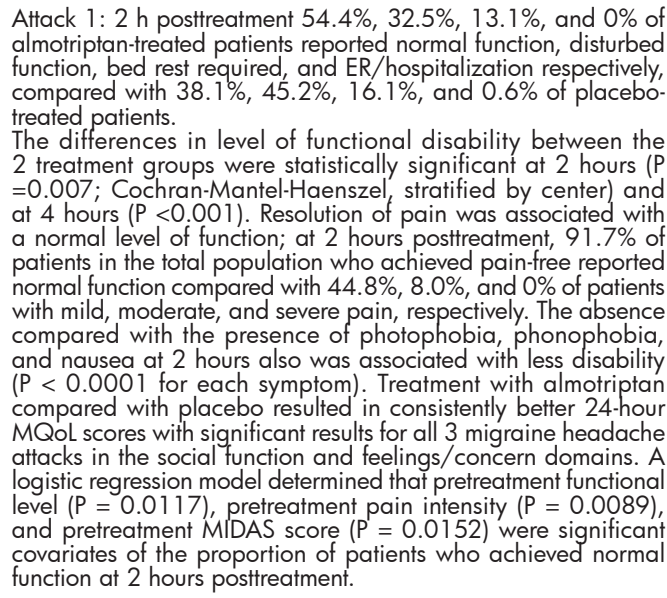 \\
\hline Freitag et al. ${ }^{36}$ & $\begin{array}{l}\text { Adults - RA }-41.5 \text { years (SD } \\
10.3) ; \mathrm{R}-44.3 \text { years (SD } \\
10.6) ; \mathrm{A}-42 \text { years (SD } 11.7) \text {; } \\
\mathrm{P}-45.3 \text { years (SD } 10.9) \\
\mathrm{n}=172 \text { (151 female and } 21 \\
\text { male) }\end{array}$ & $\begin{array}{l}\text { Rizatriptan } 10 \mathrm{mg}+ \\
\text { Acetaminophen } 1000 \mathrm{mg} \\
\text { (RA); Rizatriptan } 10 \mathrm{mg}(\mathrm{R}) \text {; } \\
\text { Acetaminophen } 1000 \mathrm{mg}(\mathrm{A}) \text {; } \\
\text { Placebo (P) } \\
\text { Oral tablet formulations to treat } \\
\text { a single attack of migraine }\end{array}$ & $\begin{array}{l}\text { The primary efficacy endpoint was pain relief (Grade } 0 \text { or } 1 \text { ) at } \\
2 \mathrm{~h} \text {. Pain relief } 2 \mathrm{~h}-\mathrm{RA} 90 \%, \mathrm{R} 77 \%, \mathrm{~A} 70 \%, \mathrm{P} 46 \% \text {. RA } \\
\text { was statistically superior to A and P. } \\
\text { Pain-freedom } 2 \mathrm{~h}-\mathrm{RA} 54 \%, \mathrm{R} 40 \%, \mathrm{~A} 26 \% \text {, and } \mathrm{p} 15 \% \text {. RA was } \\
\text { statistically superior to A and P. } \\
\text { Pain relief sustained } 24 \mathrm{~h}-\mathrm{RA} 62 \%, \mathrm{R} 53 \%, \mathrm{~A} 42 \% \text { and } \mathrm{P} 15 \% \text {. } \\
\text { RA was statistically superior to P only. } \\
\text { RA was statistically superior to A for absence of phonophobia } \\
(85 \% \text { vs } 60 \%, \mathrm{P}=.009 \text { ) and statistically superior to P for absence } \\
\text { of phonophobia }(85 \% \text { vs } 67 \%, \mathrm{P}=.039) \text { absence of nausea } \\
(92 \% \text { vs } 72 \%, \mathrm{P}=.021) \text {, and absence of functional disability } \\
(65 \% \text { vs } 41 \%, \mathrm{P}=.024) \text {. }\end{array}$ \\
\hline Friedman et al. ${ }^{104}$ & $\begin{array}{l}\text { Adults }-31 \text { to } 37 \text { years } \\
\text { Metoclopramide }=34 \text { years } \\
\text { (31-37); Sumatriptan }=34 \\
\text { years (31/37) } \\
\mathrm{n}=78 \text { (67 female and } 11 \text { male) }\end{array}$ & $\begin{array}{l}\text { Metoclopramide } 20 \mathrm{mg}+ \\
\text { diphenhydramine } 25 \mathrm{mg} \\
\text { administered IV } \\
\text { Sumatriptan } 6 \mathrm{mg} \mathrm{sc} \\
\text { Single attack of migraine }\end{array}$ & $\begin{array}{l}\text { The primary outcome, a comparison of the change in NRS } \\
\text { (numeral rating scale) scores between time } 0 \text { and } 2 \text { hours in } \\
\text { each arm, demonstrated a clinically and statistically insignificant } \\
\text { advantage for the metoclopramide arm: } 1.0 \text {. The secondary } \\
\text { outcome, a comparison of the change in NRS (numeral rating } \\
\text { scale) score between time } 0 \text { and } 24 \text { hours, revealed a clinically } \\
\text { and statistically insignificant advantage for the metoclopramide } \\
\text { arm: } 1.1 \text { At } 2 \\
\text { hours - } 59 \% \text { of metoclopramide subjects and } 35 \% \text { of sumatriptan } \\
\text { subjects were pain-free. }\end{array}$ \\
\hline Friedman et al. ${ }^{105}$ & $\begin{array}{l}\text { Adults - TMB/DPH } 34 \text { (9.7) } \\
\text { and Sumatriptan } 32 \text { ( } 8.9 \text { ) years } \\
n=40 \text { ( } 37 \text { female and } 3 \text { male) }\end{array}$ & $\begin{array}{l}\text { Trimethobenzamide } 200 \mathrm{~g}+ \\
\text { diphenhydramine } 25 \mathrm{mg} \text { (TMB/ } \\
\text { DPH) as a single intramuscular } \\
\text { injection } \\
\text { Sumatriptan 6mg SC }\end{array}$ & $\begin{array}{l}\text { By } 2 \text { hours sumatriptan subjects had improved by a mean of } 6.1 \\
\text { and the TMB/DPH subjects had improved by a mean of } 4.4 \text { ( } 95 \% \\
\mathrm{CI} \text { for difference of } 1.7:-0.1 \text { to } 3.4) \text {. } \\
\text { By } 24 \text { hours after medication administration, sumatriptan subjects } \\
\text { had a mean improvement from baseline of } 4.9 \text { as compared to } \\
5.3 \text { for TMB ( } 95 \% \mathrm{Cl} \text { for difference of }-0.4:-2.4 \text { to } 1.6) \text {. } \\
\text { The need for rescue medication was comparable between the } \\
\text { groups. No serious or frequent adverse effects were noted in } \\
\text { either group }\end{array}$ \\
\hline Friedman et al. ${ }^{106}$ & $\begin{array}{l}\text { Adults - } 18 \text { to } 64 \text { years } \\
n=166 \text { ( } 144 \text { female and } 22 \\
\text { male) }\end{array}$ & $\begin{array}{l}\text { Oral Naproxen } 500 \mathrm{mg} \\
\text { Oral Sumatriptan } 100 \mathrm{mg} \\
\text { Single attack migraine }\end{array}$ & $\begin{array}{l}\text { Naproxen group improved by a mean of } 4.3 \mathrm{NRS} \text { (numeral rating } \\
\text { scale) points, whereas the sumatriptan group improved by } 4.1 \\
\text { points ( } 95 \% \mathrm{Cl} \text { for difference of } 0.2 \text { points: } 0.7 \text { to } 1.1 \text { points). } \\
\text { Findings were virtually identical among the migraine subset }(4.3 \\
\text { versus } 4.2 \mathrm{NRS} \text { points; } 95 \% \mathrm{Cl} \text { for difference of } 0.1 \text { points: } 1.3 \\
\text { to } 1.5 \text { points). } \\
\text { Would patients want to take the same medication the next time: } \\
71 \% \mathrm{Naproxen}(95 \% \mathrm{Cl} 62 \% \text { to } 80 \% \text { ) and } 75 \%(95 \% \mathrm{Cl} 66 \% \\
\text { to } 84 \% \text { ) of sumatriptan patients answered yes. } \\
\text { Adverse effect profiles were also comparable }\end{array}$ \\
\hline Friedman et al. ${ }^{107}$ & $\begin{array}{l}\text { Adults }-18 \text { to } 63 \text { years } \\
n=35 \text { ( } 28 \text { females and } 7 \text { males })\end{array}$ & $\begin{array}{l}\text { Maxillary intraoral chilling (MIC) } \\
40 \text { minutes of bilateral } \\
\text { Sumatriptan } 50 \text { mg oral } \\
\text { Sham (tongue) chilling }\end{array}$ & $\begin{array}{l}\text { Significant mean headache relief was obtained by maxillary } \\
\text { chilling and sumatriptan at all time intervals ( } 1,2,4 \text { and } 24 \\
\text { hours), with poor relief obtained by placebo. Maxillary chilling } \\
\text { was more effective than sumatriptan at all time intervals. } \\
\text { Significant nausea relief was obtained by maxillary chilling } \\
\text { and sumatriptan at posttreatment and } 2 \text { and } 4 \text { hours later. At } \\
24 \text { hours, some headache and nausea recurrence were noted } \\
\text { with sumatriptan. The repeated-measures analysis of variance } \\
\text { indicated that both treatments, drug ( } P=0.024) \text { and maxillary } \\
\text { chilling ( } P=0.001) \text {, reduced the headache compared to the } \\
\text { control group. }\end{array}$ \\
\hline
\end{tabular}




\begin{tabular}{|c|c|c|c|}
\hline Fujita et al. ${ }^{49}$ & $\begin{array}{l}\text { Children and adolescents: } \\
\text { Sumatriptan } 25 \mathrm{mg}: 14.5 \\
(2.18) \text {; Sumatriptan } 50 \mathrm{mg}: \\
14.1 \text { (1.96) and Placebo: } 13.9 \\
(2.04) \\
\mathrm{n}=144 \text { (female } 84 \text { and male } \\
60)\end{array}$ & $\begin{array}{l}\text { Sumatriptan } 25 \text { and } 50 \text { mg oral } \\
\text { Placebo } \\
\text { Single migraine attack }\end{array}$ & $\begin{array}{l}\text { Patients who report pain relief at } 2 \mathrm{~h} \text { post-treatment for the primary } \\
\text { endpoint was higher in the placebo group than in the pooled } \\
\text { sumatriptan group }(38.6 \% \text { vs } 31.1 \%, 95 \% \mathrm{Cl}: 23.02 \text { to } 8.04 \text {, } \\
\mathrm{p}=0.345) \text {. } \\
\text { Patients who reported pain relief at } 4 \mathrm{~h} \text { post-dose was higher in } \\
\text { the pooled sumatriptan group ( } 63.5 \%) \text { than in the placebo group } \\
(51.4 \%) \text { but failed to achieve statistical significance }(\mathrm{p}=0.142) \text {. } \\
\text { At } 4 \mathrm{~h} \text { post-dose, percentages of patients who were pain free } \\
\text { or had complete relief of photophobia or phonophobia were } \\
\text { numerically higher in the sumatriptan pooled group compared } \\
\text { to placebo. }\end{array}$ \\
\hline $\begin{array}{l}\text { Gallagher et } \\
\text { al. }{ }^{108}\end{array}$ & $\begin{array}{l}\text { Adults - zolmitriptan } 2.5 \mathrm{mg} \\
39.9 \text { (10.0); } 5 \mathrm{mg} 40.2(10.5) \text {; } \\
\text { Sumatriptan } 25 \mathrm{mg} 39.6 \\
(10.2) ; 50 \mathrm{mg} 40.6(10.2) \\
\text { years } \\
\mathrm{n}=1212 \text { (1062 female and } \\
150 \text { male) }\end{array}$ & $\begin{array}{l}\text { Zolmitriptan } 2.5 \mathrm{mg}, 5 \mathrm{mg} \text { tablet } \\
\text { Sumatriptan } 25 \text { and } 50 \mathrm{mg} \\
\text { tablet } \\
\text { Treat a first and second } \\
\text { (recurrence a single migraine } \\
\text { attack) migraine attack }\end{array}$ & 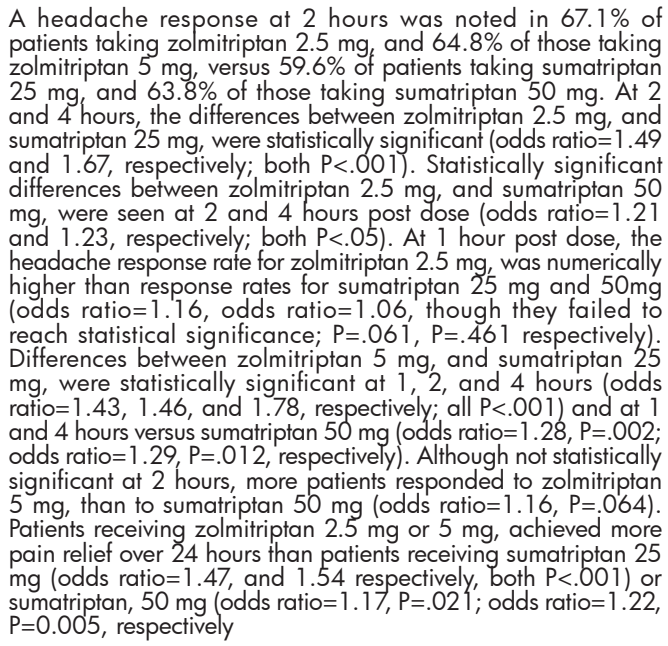 \\
\hline $\begin{array}{l}\text { Garcia-Ramos et } \\
\text { al. }{ }^{109}\end{array}$ & $\begin{array}{l}\text { Adults - Eletriptan }-36.3 \pm \\
11.1 \text {; Naratriptan } 37.5 \pm 11 ; \\
\text { Placebo } 36.4 \pm 11.1 \text { years } \\
\mathrm{n}=483 \text { ( } 390 \text { female and } 93 \\
\text { male) }\end{array}$ & $\begin{array}{l}\text { Eletriptan } 40 \mathrm{mg} \text { tablet } \\
\text { Naratriptan } 2.5 \mathrm{mg} \text { capsule } \\
\text { Placebo } \\
\text { Single migraine attack }\end{array}$ & 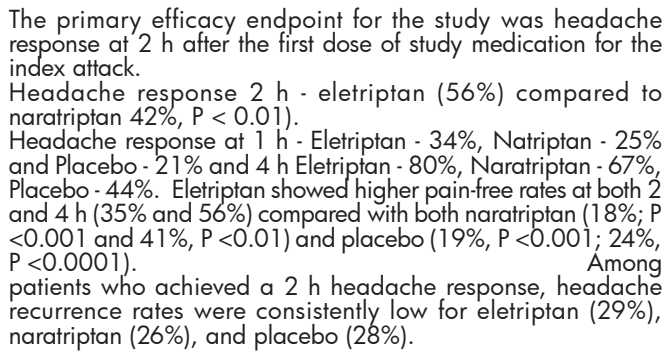 \\
\hline Geraud et al. ${ }^{110}$ & 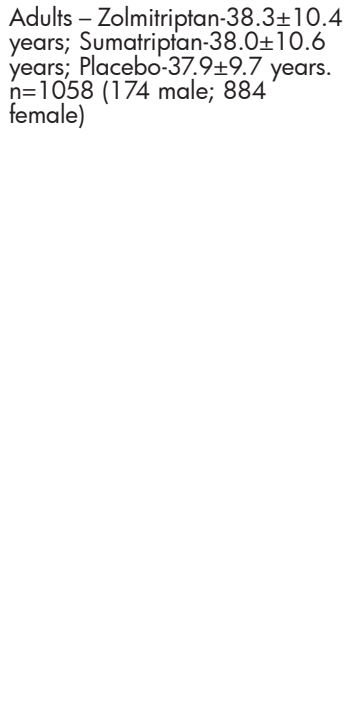 & $\begin{array}{l}\text { zolmitriptan } 5 \mathrm{mg} \text { or } \\
\text { sumatriptan } 100 \mathrm{mg} \\
\text { placebo } \\
\text { a single oral dose }\end{array}$ & $\begin{array}{l}\text { A reduction in headache pain from moderate/severe at baseline } \\
\text { to mild or no pain } 2 \mathrm{~h} \text { after taking study medication with no } \\
\text { moderate or severe recurrence within } 24 \mathrm{~h} \text { (Primary Endpoint) } \\
\text { was reported by } 39 \%, 38 \% \text { and } 32 \% \text { of patients treated with } \\
\text { zolmitriptan, sumatriptan and placebo, respectively, with no } \\
\text { significant difference between treatment groups. In patients } \\
\text { with moderate headache at baseline, complete response } \\
\text { was significantly greater following zolmitriptan than after } \\
\text { placebo ( } 48 \% \text { vs. } 27 \% \text {; P50.0 } 1 \text { ); there was no significant } \\
\text { difference between sumatriptan and placebo groups ( } 40 \% \\
\text { vs. } 27 \% \text { ). In patients with severe baseline headache (where } \\
\text { a greater reduction in headache intensity is required for a } \\
\text { headache response), there was no significant difference } \\
\text { between any groups in complete headache response rates. } \\
\text { Secondary objectives were to compare headache and pain-free } \\
\text { response rates at } 1,2 \text { and } 4 \text { h post-dose. In addition, other } \\
\text { secondary objectives were to compare the proportion of patients } \\
\text { whose migraine-associated symptoms were effectively treated, } \\
\text { use of escape medication after } 2 \text { h, incidence of recurrence, } \\
\text { meaningful migraine relief, time to meaningful migraine relief, } \\
\text { and degree of activity impairment at } 1,2,4 \text { and } 24 \text { h. For these } \\
\text { secondary endpoints, active treatment groups were significantly } \\
\text { superior to placebo for: } 1-, 2-\text { and } 4-h \text { headache response (e.g. } \\
2-h \text { headache response rates: zolmitriptan } 59 \% \text {; sumatriptan } \\
61 \% \text {; placebo } 44 \% ; P=0.01 \text { vs. placebo); pain-free response } \\
\text { rates at } 2 \text { and } 4 \text { h; alleviation of nausea and vomiting; use } \\
\text { of escape medication and restoration of normal activity. The } \\
\text { incidence of adverse events was similar between zolmitriptan and } \\
\text { sumatriptan groups but was slightly lower in the placebo group. }\end{array}$ \\
\hline
\end{tabular}




\begin{tabular}{|c|c|c|c|}
\hline $\begin{array}{l}\text { Geraud, } \\
\text { Compagnon, } \\
\text { Rossi111 }\end{array}$ & $\begin{array}{l}\text { Adults }-41.6 \pm 10.0 \text { and } \\
40.9 \pm 10.7 \text { years } n=666(100 \\
\text { male and } 566 \text { female) }\end{array}$ & $\begin{array}{l}\text { Zolmitriptan } 2.5 \mathrm{mg} \text { oral } \\
\text { Acetylsalicylic acid } 900 \mathrm{mg}+ \\
\text { metoclopramide } 10 \mathrm{mg} \text { oral } \\
\text { First and second (recurrence a } \\
\text { single migraine attack) migraine } \\
\text { attack }\end{array}$ & $\begin{array}{l}\text { The percentage of patients with a } 2 \text {-hour headache response after } \\
\text { the first dose (primary endpoint) was } 33.4 \% \text { with zolmitriptan and } \\
32.9 \% \text { with acetylsalicylic acid plus metoclopramide [odds ratio } \\
1.06,95 \% \text { confidence interval (Cl) } 0.77-1.47 ; \mathrm{p}=0.7228 \text { ] } \\
\text { For most secondary endpoints, the two treatments demonstrated } \\
\text { comparable efficacy. }\end{array}$ \\
\hline $\begin{array}{l}\text { Ghaderibarmi, } \\
\text { Tavakkoli, } \\
\text { Rossi }^{112}\end{array}$ & $\begin{array}{l}\text { Adults - Sumatriptan - } \\
36.17 \pm 7.57 ; \\
\text { Valproate }-38.61 \pm 11.41 \\
\text { years } \\
\mathrm{n}=37 \text { ( } 7 \text { male and } 30 \text { female) }\end{array}$ & $\begin{array}{l}\text { Sumatriptan } 6 \mathrm{mg} \mathrm{SC} \\
\text { Valproate } 15 \mathrm{mg} / \mathrm{Kg} \text { IV } \\
\text { Single migraine attack }\end{array}$ & $\begin{array}{l}\text { The outcomes including pain severity at } 0.5,1,2,4,24 \text {, and } 48 \\
\text { hours after injection (VAS score was used to migraine severity). } \\
\text { Sumatriptan VAS Score (before treatment: } 0.84 \text { ): } 0.5 \mathrm{~h}-0.01 \text {, } \\
1 \mathrm{~h}-0.023,2 \mathrm{~h}-0.3,4 \mathrm{~h}-0.99,24 \mathrm{~h}-0.68,48 \mathrm{~h}-0.46 \text {. } \\
\text { Valproate VAS Score (before treatment: } 8.31 \text { ): } 0.5 \mathrm{~h}-3.31,1 \mathrm{~h}- \\
2.26,2 \mathrm{~h}-2.15,4 \mathrm{~h}-2.10,24 \mathrm{~h}-1.68,48 \mathrm{~h}-1.31\end{array}$ \\
\hline Gijsmant et al. ${ }^{113}$ & $\begin{array}{l}\text { Adults - mean age } 39.2 \text { years } \\
n=418 \text { (Female: } 361 \text { and } \\
\text { Male: } 57 \text { ) }\end{array}$ & $\begin{array}{l}\text { Rizatriptan } 2.5 \mathrm{mg}, 5 \mathrm{mg}, 10 \mathrm{mg} \\
\text { Placebo } \\
\text { Sigle migraine attack }\end{array}$ & $\begin{array}{l}\text { At the primary timepoint of } 2 \mathrm{~h} \text { after the initial dose, the proportion } \\
\text { of patients reporting pain relief was } 47.6 \% \text { for rizatriptan } 10 \mathrm{mg} \text {; } \\
45.4 \% \text { for rizatriptan } 5 \mathrm{mg} ; 21.3 \% \text { for rizatriptan } 2.5 \mathrm{mg} \text {; and } \\
17.9 \% \text { for pacebo. Seventy percent of patients on rizatriptan } 10 \\
\text { mg reported pain relief at } 4 \mathrm{~h} \text {. }\end{array}$ \\
\hline Goadsby et al. ${ }^{114}$ & $\begin{array}{l}\text { Adults - } 39 \text { (SD 10) years } \\
\mathrm{n}=61 \text { ( } 10 \text { male and } 51 \text { female) }\end{array}$ & $\begin{array}{l}\text { Oral Sumatriptan } 100 \mathrm{mg} \\
\text { Placebo } \\
\text { Single migraine attack }\end{array}$ & $\begin{array}{l}\text { Positive result was defined as a reduction in headache grade } \\
\text { from } 3 \text { or } 2 \text { to } 0 \text { or } 1 . \\
\text { Reduction headache grade - Sumatriptan } 45 / 89 \text { [51 \%] vs } \\
\text { Placebo } 9 / 93 \text { [10\%]; }<0.01, \times 2 \text { test). } \\
\text { Use of rescue medication at } 2 \mathrm{~h} \text { - Sumatriptan } 88 \% \text { vs Placebo } \\
41 \%(\mathrm{p}<0.05) \text {. } \\
\text { Of the } 28 \text { patients who were headache-free at } 2 \mathrm{~h} \text { after } \\
\text { sumatriptan, } 11(39 \%) \text { had a recurrence of headache within } \\
\text { the next } 24 \mathrm{~h} \text {. }\end{array}$ \\
\hline Goadsby et al. ${ }^{115}$ & $\begin{array}{l}\text { Adults }-40 \text { years ( } 18 \text { to } 64) \\
\text { [placebo: } 41 \pm 10(21-66) \\
\text { years; sumatriptan-100mg: } \\
40 \pm 10 \text { ( } 18-68 \text { ) years; } \\
\text { eletriptan-20mg: } 40 \pm 11 \\
\text { (18-68) years; eletriptan- } \\
40 \mathrm{mg}: 41 \pm 11 \text { ( } 19-71 \text { ) years; } \\
\text { eletriptan-80 mg: } 40 \pm 11 \text { years } \\
\text { (18-67); ] years. } \\
\text { n=692 (568 females and } 124 \\
\text { males) }\end{array}$ & $\begin{array}{l}\text { Eletriptan ( } 20 \mathrm{mg}, 40 \mathrm{mg} \text {, or } 80 \\
\text { mg) tablet } \\
\text { Sumatriptan ( } 100 \mathrm{mg} \text { ) capsules } \\
\text { Placebo } \\
\text { Single migraine attack, a } \\
\text { second double-blind dose of } \\
\text { study medication could be } \\
\text { administered }\end{array}$ & 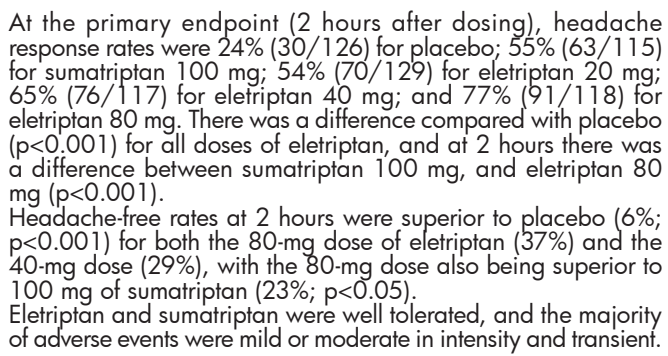 \\
\hline Goadsby et al. ${ }^{116}$ & $\begin{array}{l}\text { Adults - Almotriptan } 39 \pm 11 \\
\text { and Zolmitriptan } 40 \pm 11 \text { years } \\
\mathrm{n}=1062(902 \text { female and } 160 \\
\text { male) }\end{array}$ & $\begin{array}{l}\text { Almotriptan } 12.5 \mathrm{mg} \text { oral } \\
\text { Zolmitriptan } 2.5 \mathrm{mg} \text { oral } \\
\text { single migraine attack }\end{array}$ & $\begin{array}{l}\text { The primary endpoint was sustained pain free plus no adverse } \\
\text { events, other endpoints included pain relief and pain free at } \\
\text { several time points, sustained pain free, headache recurrence, } \\
\text { use of rescue medication, functional impairment, time lost because } \\
\text { of migraine, treatment acceptability, and overall treatment } \\
\text { satisfaction. } \\
2-\mathrm{h} \text { pain relief: Almotriptan } 65.4 \% \text {; Zolmitriptan: } 70.2 \% \text { ( } \mathrm{p}= \\
0.094 \text { ) } \\
\text { Pain relief at } 24 \mathrm{~h} \text { : Almotriptan } 82.9 \% \text {; Zolmitriptan: } 83.8 \% \\
\text { (p=0.699) } \\
2 \mathrm{~h} \text { pain free: Almotriptan } 43.5 \% \text {; Zolmitriptan: } 48.3 \% \text { ( } \mathrm{p}= \\
0.117 \text { ). }\end{array}$ \\
\hline Göbel et al. ${ }^{117}$ & $\begin{array}{l}\text { Adults - mean age } 45 \text { years } \\
n=253 \text { ( } 230 \text { female and } 23 \\
\text { male) }\end{array}$ & $\begin{array}{l}\text { Naratriptan } 2.5 \mathrm{mg} \text { tablet } \\
\text { Sumatriptan } 100 \mathrm{mg} \text { tablet } \\
\text { single migraine attack }\end{array}$ & $\begin{array}{l}\text { Of the } 164 \text { naratriptan-treated and } 181 \text { sumatriptan-treated } \\
\text { patients experiencing headache relief after } \geq 1 \text { attack, headache } \\
\text { recurrence } 4 \text { to } 24 \text { hours after treatment was reported by } 74 \\
\text { naratriptan-treated patients ( } 45 \% \text { ) and } 101 \text { sumatriptan-treated } \\
\text { patients ( } 57 \% \text {; not statistically significant). } \\
\text { n a subset of patients experiencing headache relief after } 2 \\
\text { attacks, headache recurrence } 4 \text { to } 24 \text { hours after initial dosing } \\
\text { was reported by } 55 \text { naratriptan and } 77 \text { sumatriptan-treated } \\
\text { patients ( } 41 \% \text { and } 57 \% \text {, respectively; } P=0.005) \text {. } \\
\text { The overall incidence of adverse events was } 22 \% \text { after treatment } \\
\text { with naratriptan and } 33 \% \text { after treatment with sumatriptan. This } \\
\text { incidence did not increase after the use of the second dose of } \\
\text { naratriptan (20\%) or sumatriptan }(31 \%) \text {. }\end{array}$ \\
\hline Goldstein et al. ${ }^{118}$ & $\begin{array}{l}\text { Adults - mean age } 40.2 \text { years } \\
n=1,329(1,167 \text { female and } \\
\text { male 162) }\end{array}$ & $\begin{array}{l}\text { Rizatriptan } 5 \text { and } 10 \mathrm{mg} \text { oral } \\
\text { Sumatriptan } 25 \text { and } 50 \mathrm{mg} \text { oral } \\
\text { two migraine attacks }\end{array}$ & $\begin{array}{l}\text { The outcomes were time to pain relief (comparison between } \\
\text { drugs) and pain relief at } 2 \text { hours. } \\
\text { Pain relief - HR rizatriptan } 5 \mathrm{mg} \text { vs sumatriptan } 25 \mathrm{mg}=1.16 \text {, } \\
\text { suggesting that patients on rizatriptan } 5 \mathrm{mg} \text { are } 16 \% \text { more likely } \\
\text { to achieve pain relief in comparison to patients on sumatriptan } 25 \\
\text { mg. HR rizatriptan } 10 \mathrm{mg} \text { vs sumatriptan } 50 \mathrm{mg}=1.14 \text { suggesting } \\
\text { that patients on rizatriptan } 10 \mathrm{mg} \text { are } 14 \% \text { more likely to achieve } \\
\text { pain relief in compariton to patients on sumatriptan } 50 \mathrm{mg} \text {. } \\
\text { Pain relief at } 2 \mathrm{~h}-\text { Rizatriptan } 5 \mathrm{mg}-33 \% \text {, Sumatriptan } 25 \mathrm{mg} \text { - } \\
28 \% \text {, Rizatriptan } 10 \mathrm{mg}-72 \% \text {, Sumatriptan } 50 \mathrm{mg}-68 \% \text {, Placebo } \\
-38 \%\end{array}$ \\
\hline
\end{tabular}




\begin{tabular}{|c|c|c|c|}
\hline Goldstein et al. ${ }^{119}$ & $\begin{array}{l}\text { Adults - mean age } 38.1 \text { years } \\
n=171 \text { ( } 136 \text { female and } 35 \\
\text { male) }\end{array}$ & $\begin{array}{l}\text { AAC (acetaminophen } 500 \mathrm{mg} \text {, } \\
\text { aspirin } 500 \mathrm{mg} \text {, caffeine } 130 \\
\text { mg) } \\
\text { Sumatriptan succinate } 50 \mathrm{mg}(25 \\
\text { mg per tablet) } \\
\text { Placebo } \\
\text { All study medications were } \\
\text { individually encapsulated in } \\
\text { hard gelatin capsules }\end{array}$ & $\begin{array}{l}\text { AAC group experienced significantly greater pain intensity } \\
\text { reduction or pain relief than those taking S50 or placebo. Pain } \\
\text { intensity reduction and pain relief score for Sumatriptan } 50 \mathrm{mg} \\
\text { group were higher than placebo group, but not to a statistically } \\
\text { significant degree. } \\
\text { Reduction of headache pain intensity from moderate/severe to } \\
\text { mild/none - Sumatriptan } 50 \mathrm{mg} \text { group was significantly superior to } \\
\text { AAC ( } 30 \text { minutes postdose); AAC group was significantly greater } \\
\text { than in the Sumatriptan } 50 \mathrm{mg} \text { group ( } 2,3 \text { and } 4 \text { hours postdose). } \\
\text { The response rate of AAC versus placebo was significant from } \\
90 \text { minutes. The rate of response in the Sumatriptan } 50 \text { mg group } \\
\text { was greater than that in the placebo group at all time points, but } \\
\text { not to a statistically significant degree. } \\
\text { Utilization of the rescue medication showed statistically significant } \\
\text { difference between Sumatriptan } 50 \text { mg group (11.9\% subjects) } \\
\text { versus the AAC group ( } 1.5 \% \text { of subjects), at } 4 \text { hours postdose. }\end{array}$ \\
\hline Goldstein et al. ${ }^{120}$ & $\begin{array}{l}\text { Adults - Sumatriptan ITS - } 40,7 \\
\text { (SD 11,2) Placebo - } 41 \text { (SD } \\
11 \text { ) years } \\
\mathrm{n}=454 \text { ( } 386 \text { female and } 68 \\
\text { male) }\end{array}$ & $\begin{array}{l}\text { Sumatriptan transdermal system } \\
6.5 \mathrm{mg} \\
\text { Placebo patch } \\
\text { Dose timing began at patch } \\
\text { activation. Patients remained } \\
\text { on study until one migraine } \\
\text { headache was treated with } \\
\text { the study patch or } 2 \text { months } \\
\text { following randomization, } \\
\text { whichever occurred first }\end{array}$ & $\begin{array}{l}\text { Significantly greater proportion of patients who received the } \\
\text { sumatriptan transdermal system were headache pain-free } 2 \\
\text { hours after patch activation compared with placebo ( } 18 \% \text { vs } \\
9 \% \text {, respectively; } p=0.0092 \text { ). The sumatriptan transdermal system } \\
\text { was associated with a significantly higher percentage of patients } \\
\text { reporting headache pain relief } 2 \text { hours postdose }(52.9 \% \text { vs } \\
28.6 \% \text {, respectively; } P<0.0001) \text {. }\end{array}$ \\
\hline Gross et al. ${ }^{121}$ & $\begin{array}{l}\text { Adults - Sumatriptan }-44 \pm \\
10.2 \text {; Placebo }-43 \pm 11.3 \\
\text { years } \\
n=86 \text { ( } 69 \text { female and } 17 \text { male) }\end{array}$ & $\begin{array}{l}\text { Sumatriptan } 6 \mathrm{mg} \mathrm{sc} \\
\text { Placebo } \\
\text { Single migraine attack }\end{array}$ & $\begin{array}{l}\text { Primary efficacy was headache relief at } 60 \text { minutes after the } \\
\text { first injection. } \\
\text { Headache relief } 1 \text { hour post treatment - Sumatriptan } 42 / 48(88 \%) \\
\text { vs Placebo } 2 / 18(11 \%)(P<0.001) \text {. } \\
\text { Rate treatment as good or excellent - Sumatriptan }(47 / 60,78 \%) \\
\text { vs Placebo }(4 / 26,15 \%) \text {. } \\
\text { Second dose-Sumatriptan ( } 17 / 20,85 \%) \text { to treat recurrence and } \\
\text { Placebo }(21 / 24,88 \%) \text { to treat an ongoing headache following } \\
\text { an ineffective response to the first dose. } \\
\text { Adverse events - Sumatriptan } 55 \%(33 / 60) \text { vs Placebo } 15 \% \\
(4 / 26) \text {. }\end{array}$ \\
\hline $\begin{array}{l}\text { Gruffydd-Jones } \\
\text { et al. } 21\end{array}$ & $\begin{array}{l}\text { Adults - had been less than } 50 \\
\text { years old. } \\
n=401 \text { ( } 329 \text { female and } 72 \\
\text { male) }\end{array}$ & $\begin{array}{l}\text { Sumatriptan } 100 \mathrm{mg} \text { oral and } \\
\text { Sumatriptan } 6 \mathrm{mg} \text { subcutaneous } \\
\text { Three migraine attacks }\end{array}$ & $\begin{array}{l}\text { Over } 70 \% \text { of patients who treated attack } 1 \text { in both treatment } \\
\text { periods of the crossover phase reported headache relief with } \\
\text { each formulation at } 4 \mathrm{~h} \text {. Only } 3 \% \text { of patients failed to respond } \\
\text { to at least one of the formulations at this time point. } \\
\text { At the end of the crossover phase patient preference for the } \\
\text { injection more than doubled from the pretreatment level in those } \\
\text { patients who were previously naive to sumatriptan. During the } \\
\text { optional phase of the study, } 38 \% \text { of patients chose to treat some } \\
\text { attacks with oral and some with subcutaneous sumatriptan }\end{array}$ \\
\hline $\begin{array}{l}\text { Gruffyd-Jones et } \\
\text { al. }{ }^{122}\end{array}$ & $\begin{array}{l}\text { Adults }- \text { Zolmitriptan } 5 \mathrm{mg}= \\
41.7 \pm 10.6 ; \text { Zolmitriptan } \\
2,5 \mathrm{mg}=42.1 \pm 10.7 ; \\
\text { Sumatriptn } 41.9 \pm 10.7 \text { years. } \\
\mathrm{n}=1522(1299 \text { female and } 223 \\
\text { male) }\end{array}$ & $\begin{array}{l}\text { Zolmitriptan } 5 \text { and } 2.5 \mathrm{mg} \\
\text { tablets } \\
\text { Sumatriptan } 50 \mathrm{mg} \text { tablets } \\
\text { Single migraine attack }\end{array}$ & $\begin{array}{l}\text { There were } 2 \text { primary efficacy endpoints: headache response at } \\
2 \mathrm{~h} \text { after treatment and proportion of patients with a headache } \\
\text { response at } 2 \mathrm{~h} \text { after the first dose of study medication across all } \\
\text { attacks treated. } \\
\text { response at } 2 \mathrm{~h} \text { : Zolmitriptan } 5 \mathrm{mg}-65.7 \% \text { vs Zomitriptan } 2,5 \mathrm{mg} \\
-62.9 \% \text { vs Sumatriptan } 50 \mathrm{mg}-66,6 \% \text { (there were no difference } \\
\text { between response rates in all treated attacks with } 3 \text { study } \\
\text { medications, there were no statistically difference post } 1 \text { or } 4 \mathrm{~h} \text { ). } \\
\text { Proportion of patients with } 2 \mathrm{~h} \text { response: Zolmitriptan } 5 \mathrm{mg}- \\
44.4 \% \text { patients had a response in }>80 \% \text { of attacks, Zolmitriptan } \\
2.5 \mathrm{mg}-38,6 \% \text { patients had a response in }>80 \% \text { of attacks, } \\
\text { Sumatriptan } 50 \mathrm{mg}-43.1 \% \text { patients had a response in }>80 \% \text { of } \\
\text { attacks ( } \mathrm{p}=0.14 \text { versus zolmitriptan } 2.5 \mathrm{mg} \text { and } \mathrm{p}=0.55 \text { versus } \\
\text { zolmitriptan } 5 \mathrm{mg} \text { ). }\end{array}$ \\
\hline $\begin{array}{l}\text { Hämäläinen, } \\
\text { Hoppu, } \\
\text { Santavuori50 }\end{array}$ & $\begin{array}{l}\text { Adolescents - } 12,3(8,3-16,4) \\
\text { years } \\
n=23[12 \text { female }(52 \%) \text { and } 11 \\
\text { male }(48 \%)]\end{array}$ & $\begin{array}{l}\text { Sumatriptan } 50 \mathrm{mg} \text { oral for a } \\
\text { body surface area of } 0.75 \text { to } \\
1.5 \mathrm{~m} 2 \\
\text { Oral Sumatriptan } 100 \mathrm{mg} \text { for a } \\
\text { body surface area of }>1.5 \mathrm{~m} 2 \\
\text { Placebo } \\
\text { One migraine attack with } \\
\text { sumatriptan and for one with a } \\
\text { matching placebo in random } \\
\text { order }\end{array}$ & $\begin{array}{l}\text { The primary endpoint of clinical efficacy was reduction of pain } \\
\text { intensity by at least } 50 \% \text { after } 2 \text { hours. } \\
\text { At } 2 \text { hours, reduction of pain intensity by } 50 \% \text { - } \\
\text { Sumatriptan } 7 / 23 \text { ( } 30 \% \text { ) vs placebo } 5 / 23(22 \%) \\
\text { (difference } 9 \%, 95 \% \mathrm{Cl} \text { for difference }-21 \text { to } 38 \%, \mathrm{p}=\mathrm{ns}) \text {. } \\
\text { Headache-free - Sumatriptan } 5 / 23(22 \%) \text { vs placebo } 2 / 23 \\
\text { (9\%) (difference } 13 \%, 95 \% \mathrm{Cl} \text { for difference }-9 \text { to } 35 \%, \mathrm{p}=\mathrm{ns} \text { ). }\end{array}$ \\
\hline Havanka et al. ${ }^{123}$ & $\begin{array}{l}\text { Adults }-18 \text { to } 65 \text { years } \\
n=643 \text { ( } 566 \text { female and } 77 \\
\text { male) }\end{array}$ & $\begin{array}{l}\text { Naratriptan tablets }(1,2.5,5 \text {, } \\
7.5 \text {, and } 10 \mathrm{mg}) \\
\text { Sumatriptan tablets }(100 \mathrm{mg}) \\
\text { Placebo } \\
\text { Single oral dose for a single } \\
\text { migraine attack }\end{array}$ & 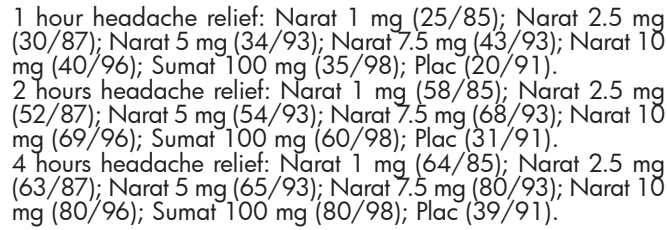 \\
\hline
\end{tabular}




\begin{tabular}{|c|c|c|c|}
\hline Henry, d'Allens ${ }^{124}$ & $\begin{array}{l}\text { Adults - Mean age was } \\
\text { Sumatriptan } 44 \pm 1.7 \text { and } \\
\text { Placebo } 42 \pm 1,6 \text { years. } \\
n=76 \text { ( } 10 \text { males and } 66 \\
\text { females) }\end{array}$ & $\begin{array}{l}\text { Sumatriptan } 6 \mathrm{mg} \text { SC } \\
\text { Placebo } \\
\text { Patients having inadequate relief } \\
\text { were allowed to use a second } \\
\text { injection of test medication } 1 \\
\text { hour later and rescue treatment } \\
\text { between } 2 \text { hours and } 24 \text { hours } \\
\text { after the first dose. }\end{array}$ & $\begin{array}{l}\text { Headache relief was achieved within } 2 \text { hours after Sumatriptan in } \\
26 \text { patients }(70 \%) \text { compared to } 8 \text { patients }(21 \%) \text { in the placebo } \\
\text { group }(p<0.0001) \text {. Of these patients, } 19(51 \%) \text { and } 3(8 \%) \text { were, } \\
\text { respectively, pain free at this time. } \\
\text { A second injection of Sumatriptan was used respectively by } 13 \\
(35 \%) \text { and } 22(58 \%) \text { patients }(p<0,024) \text {. }\end{array}$ \\
\hline Ho et al..$^{51}$ & $\begin{array}{l}\text { Adolescents } 6-17 \text { years old and } \\
\text { mean } 13.0(2.9) \text { years. } \\
n=977 \text { (female } 550 \text { and male } \\
427)\end{array}$ & $\begin{array}{l}\text { Rizatriptan ( } 5 \mathrm{mg} \text { for }<40 \mathrm{~kg} \text {, } \\
10 \mathrm{mg} \text { for } \geq 40 \mathrm{~kg} \text { ) } \\
\text { Placebo } \\
\text { Patients with moderate/ } \\
\text { severe pain (non-responders) } \\
\text { proceeded to take study } \\
\text { medication in Stage } 2\end{array}$ & $\begin{array}{l}\text { A higher proportion of } 12-17 \text { year old on rizatriptan had pain } \\
\text { freedom at } 2 \text { hours compared with those on placebo, } 87 / 284 \\
(30.6 \%) \text { versus } 63 / 286(22.0 \%) \text {, odds ratio }=1.55 \text { [95\% Cl: } \\
1.06 \text { to } 2.26], p=0.025 \text {. Adverse events within } 14 \text { days of dose } \\
\text { in } 12-17 \text { year old were similar for rizatriptan and placebo. The } \\
\text { pattern of findings was similar in } 6-17 \text { year old. }\end{array}$ \\
\hline Ishkanian et al. ${ }^{125}$ & $\begin{array}{l}\text { Adults - sumatriptan } 39.6 \pm 12.3 \\
(18-70) \text { years; placebo } \\
41.0 \pm 11.3 \text { (18-60) years. } \\
\mathrm{n}=215 \text { (151 females and } 64 \\
\text { males) }\end{array}$ & $\begin{array}{l}\text { Sumatriptan } 50 \text { mg tablet } \\
\text { Placebo } \\
\text { Single migraine attack }\end{array}$ & $\begin{array}{l}\text { Significantly more patients treated with sumatriptan } 50 \mathrm{mg} \\
\text { achieved a positive headache response at } 2 \text { and } 4 \text { hours after } \\
\text { administration compared with those treated with placebo ( } 69 \% \\
\text { vs } 43 \% \text { at } 2 \text { hours and } 76 \% \text { vs } 49 \% \text { at } 4 \text { hours, respectively; } \\
\text { both, } P<0.001 \text { ). } \\
\text { Significantly more sumatriptan-treated patients were free from } \\
\text { sinus pain compared with placebo recipients at } 2 \text { hours ( } 63 \% \text { vs } \\
49 \% \text { placebo, } P=0.049 \text { ) and } 4 \text { hours ( } 77 \% \text { vs } 55 \%, P=0.001) \text {. } \\
\text { All treatments were generally well tolerated. The most common } \\
\text { drug-related AEs reported in the sumatriptan and placebo groups, } \\
\text { respectively, were dizziness ( } 5 \% \text { vs }<1 \% \text { ), nausea ( } 3 \% \text { vs } 2 \% \text { ). } \\
\text { No patients experienced any serious adverse effects. }\end{array}$ \\
\hline Jelinski et al. ${ }^{126}$ & $\begin{array}{l}\text { Adults }- \text { mean age of } 40 \text { years } \\
{[(39.8 \pm 9.7 \text { years sumatriptan }} \\
50 \mathrm{mg}, 39.8 \pm 11.4 \text { years } \\
\text { sumatriptan } 100 \mathrm{mg}, 40.7 \pm 9.8 \\
\text { years placebo)] years } \\
\mathrm{n}=361 \text { (309 females and } 52 \\
\text { males) }\end{array}$ & $\begin{array}{l}\text { Sumatriptan } 50 \mathrm{mg} \\
\text { Sumatriptan } 100 \mathrm{mg} \\
\text { Placebo } \\
\text { Single migraine attack }\end{array}$ & $\begin{array}{l}\text { Two-hour pain free rates were } 16 \%, 40 \% \text {, and } 50 \% \text { in the } \\
\text { placebo group, sumatriptan } 50 \text { mg group, and the sumatriptan } \\
100 \mathrm{mg} \text { group respectively ( } \mathrm{p}<0.001 \text {, active treatment groups } \\
\text { vs placebo). } \\
\text { The percentage of subjects who sustained a pain-free response } \\
\text { for both } 50 \mathrm{mg} \text { and } 100 \mathrm{mg} \text { sumatriptan groups ( } 24 \% \text { and } 27 \% \text { ) } \\
\text { was significantly higher than in the placebo group ( } 6 \% \text { ). } \\
\text { After } 4 \text { hours, } 25 \% \text { of the } 50 \mathrm{mg} \text { sumatriptan group and } 13 \% \text { of } \\
\text { the } 100 \mathrm{mg} \text { sumatriptan group experienced worsening of their } \\
\text { migraine pain, compared to } 46 \% \text { of placebo patients (both } \\
\mathrm{p}<0.001 \text { ). }\end{array}$ \\
\hline Jensen et al. ${ }^{127}$ & $\begin{array}{l}\text { Adults }-43 \text { years (range } 20-65) \\
\mathrm{n}=138 \text { (125 female and } 13 \\
\text { male) }\end{array}$ & $\begin{array}{l}\text { Sumatriptan } 6 \text { mg subcutaneous } \\
\text { Placebo }\end{array}$ & $\begin{array}{l}\text { Sumatriptan } 6 \text { mg sc was significantly better than placebo at } \\
30,60,90 \text { and } 120 \text { min after injection in relieving moderate } \\
\text { or severe headache to mild or none as well as relieving any } \\
\text { headache to none. At } 60 \text { min after injection, the treatment } \\
\text { response rate was } 61 \% \text { for sumatriptan and } 6 \% \text { for placebo. } \\
\text { During the following open-phase trial of four attacks treated with } \\
\text { sumatriptan, treatment response rates were } 68-74 \% \text {. } \\
\text { During the total of } 538 \text { attacks treated, } 12 \text { attempts at using the } \\
\text { self-injector failed. In the double-blind and open phases, } 81 \% \\
\text { and } 90 \% \text { of patients respectively found the device easy or very } \\
\text { easy to use. Adverse effects were benign and short lasting, but } \\
\text { led } 7 \text { patients to discontinue the study. }\end{array}$ \\
\hline Kelly et al. ${ }^{128}$ & $\begin{array}{l}\text { Adults - mean age sumatriptan } \\
32 \text { and chlorpromazine } 35 \\
\text { years } \\
n=43 \text { ( } 29 \text { Female and } 14 \text { male) }\end{array}$ & $\begin{array}{l}\text { Sumatriptan } 6 \mathrm{mg} I \mathrm{M} \\
\text { Chlorpromazine IV } 12.5 \mathrm{mg} \\
\text { increments to a maximum of } \\
37.5 \mathrm{mg}\end{array}$ & $\begin{array}{l}\text { No difference in efficacy between the sumatriptan regimen and } \\
\text { the chlorpromazine regimen was found. Adverse effects were } \\
\text { mild and equally distributed between the groups. }\end{array}$ \\
\hline $\begin{array}{l}\text { Klapper, } \\
\text { O'Connor }^{31}\end{array}$ & $\begin{array}{l}\text { Subjects age not mentioned. } \\
n=30\end{array}$ & $\begin{array}{l}\text { Rizatriptan } 10 \text { mg wafer } \\
\text { sublingual } \\
\text { Placebo } \\
\text { Single migraine attack }\end{array}$ & $\begin{array}{l}\text { The primary efficacy measure was pain relief in } 1 \text { hour. } \\
\text { Pain relief in } 1 \text { hour - Rizatriptan } 50 \%(8 / 16) \text { vs Placebo } 50 \% \\
(7 / 14) \text {. The average time to onset of significant relief - Rizatriptan } \\
\text { was } 25 \text { min vs. Placebo } 27 \text { min ( } t=1.25 \text {, NS). }\end{array}$ \\
\hline Klapper et al. ${ }^{129}$ & $\begin{array}{l}\text { Adults }- \text { Zolmitriptan } 2.5 \mathrm{mg} \\
-41.1 \pm 11.3 \text { years; Placebo - } \\
42 \pm 10.3 \text { years } \\
n=280 \text { ( } 39 \text { male and } 241 \\
\text { female) }\end{array}$ & $\begin{array}{l}\text { Zolmitriptan } 2.5 \mathrm{mg} \text { oral } \\
\text { Placebo } \\
\text { Single migraine headache }\end{array}$ & $\begin{array}{l}\text { Primary endopoint was pain-free rate (i.e. 'no pain') at } 2 \mathrm{~h} \text { after } \\
\text { the first dose of zolmitriptan } 2.5 \mathrm{mg} \text { or placebo. } \\
\text { Pain-free at } 2 \mathrm{~h}-\text { Zolmitriptan } 43.4 \% \text { vs. Placebo } 18.4 \% \text {; odds } \\
\text { ratio (OR) } 3.28,95 \% \mathrm{Cl} 1.90-5.66, \mathrm{P}<0.0001 \text {. } \\
\text { Progressed to more severe intensity within } 2 \mathrm{~h} \text { after treatment } \\
\text {-Zolmitriptan } 53.7 \% \text { vs. Placebo } 70.4 \%, \mathrm{P}<0.01 \text {. } \\
\text { At } 2 \mathrm{~h} \text { after dosing patients able to perform normal activities } \\
\text {-Zolmitriptan } 68.4 \% \text { vs. Placebo } 50.7 \%, \mathrm{P}<0.01 \text {. }\end{array}$ \\
\hline
\end{tabular}




\begin{tabular}{|c|c|c|c|}
\hline Klassen et al. ${ }^{130}$ & $\begin{array}{l}\text { Adults }-40.2 \text { years } \\
n=613(533 \text { female and } 80 \\
\text { male) }\end{array}$ & $\begin{array}{l}\text { Naratriptan tablets } 2.5 \mathrm{mg}, 1 \\
\text { mg, } 0.25 \mathrm{mg} \text { or } 0.1 \mathrm{mg} \\
\text { Placebo } \\
\text { One moderate or severe } \\
\text { migraine attack }\end{array}$ & $\begin{array}{l}\text { Headache relief (moderate or severe pain at dosing reduced } \\
\text { to mild or no pain) } 4 \text { hours postdose was reported in } 60 \% \text { of } \\
\text { patients receiving naratriptan } 2.5 \mathrm{mg} \text { compared with } 50 \%, 35 \% \text {, } \\
32 \% \text {, and } 34 \% \text { of patients receiving naratriptan } 1 \mathrm{mg}, 0.25 \mathrm{mg} \text {, } \\
0.1 \mathrm{mg} \text {, and placebo, respectively ( } P<0.05 \text { naratriptan } 2.5 \mathrm{mg} \\
\text { and } 1 \mathrm{mg} \text { versus placebo, } 1 \mathrm{mg} \text { versus } 0.1 \mathrm{mg} \text {, and } 2.5 \mathrm{mg} \\
\text { versus } 0.1 \mathrm{mg} \text { and } 0.25 \mathrm{mg} \text { ). } \\
\text { Clinical disability } 4 \text { hours postdose was reported as mild or none } \\
\text { for } 70 \% \text { of patients receiving naratriptan } 2.5 \mathrm{mg} \text { compared with } \\
63 \%, 47 \%, 48 \% \text {, and } 48 \% \text { of patients receiving naratriptan } 1 \mathrm{mg} \text {, } \\
0.25 \mathrm{mg}, 0.1 \mathrm{mg} \text {, or placebo, respectively (P<0.05 naratriptan } \\
2.5 \mathrm{mg} \text { and } 1 \mathrm{mg} \text { versus placebo, } 1 \mathrm{mg} \text { versus } 0.1 \mathrm{mg} \text {, and } \\
2.5 \mathrm{mg} \text { versus } 0.1 \text { mg and } 0.25 \mathrm{mg} \text { ). Four-hour efficacy for } \\
\text { absence of nausea, photophobia, and phonophobia was similar } \\
\text { to efficacy for headache relief at each dose. The adverse event } \\
\text { profile of each dose of naratriptan was similar to that of placebo. } \\
\text { No clinically relevant change in any safety measure was reported. }\end{array}$ \\
\hline Kolodny et al. ${ }^{131}$ & $\begin{array}{l}\text { Adults - mean age } 40 \text { years } \\
n=1,447(1,244 \text { female and } \\
203 \text { male) }\end{array}$ & $\begin{array}{l}\text { Rizatriptan } 5 \mathrm{mg} \text { tablets } \\
\text { Rizatriptan } 10 \mathrm{mg} \text { tablets } \\
\text { Sumatriptan } 25 \mathrm{mg} \text { tablets } \\
\text { Sumatriptan } 50 \mathrm{mg} \text { tablets } \\
\text { Placebo } \\
\text { Acute treatment of migraine, } \\
\text { two-attack crossover study }\end{array}$ & $\begin{array}{l}\text { The primary objective of the study was to compare } \\
\text { rizatriptan } 10 \mathrm{mg} \text { and sumatriptan } 50 \mathrm{mg} \text { in terms of } \\
\text { time-to-pain relief during the } 2 \mathrm{~h} \text { after taking study drug. } \\
\text { Hazard ratio [rizatriptan } 10 \mathrm{mg} \text { vs sumatriptan } 50 \mathrm{mg}]=1.10 \\
\text { [95\% confidence interval (Cl) } 0.96,1.26 ; \mathrm{P}=0.161] \text {. Hazard } \\
\text { ratio [Rizatriptan } 5 \mathrm{mg} \text { vs sumatriptan } 25 \mathrm{mg}]=1.22 \text { ( } 95 \% \mathrm{Cl} \\
1.06 \text {, } 1.41, \mathrm{P}=0.007 \text { ). } \\
\text { Pain-free rates at } 2 \mathrm{~h} \text { - Rizatriptan } 5 \mathrm{mg} 33,4 \% \text { vs Sumatriptan } \\
25 \mathrm{mg} 27,4 \% \text { [OD }=1,34-95 \% \mathrm{Cl} 1.05,1.72 \mathrm{p}=0,002] \\
\text { Rizatriptan } 10 \mathrm{mg}-38 \% \text { vs Sumatriptan } 50 \mathrm{mg} 33,6 \%[\mathrm{OD}=1.23 \\
-95 \% \mathrm{Cl} 0.99,1.52, \mathrm{p}=0,059] \text {. }\end{array}$ \\
\hline Kostic et al. ${ }^{132}$ & $\begin{array}{l}\text { Adults - IV Prochlorperazine } \\
\text { with diphenhydramine - } 31 \\
\text { (SD - 10); SC Sumatriptan - } 28 \\
\text { (SD - 6) years } \\
\mathrm{n}=66 \text { ( } 42 \text { female and } 24 \text { male) }\end{array}$ & $\begin{array}{l}\text { Prochlorperazine } 10 \mathrm{mg} \text { IV with } \\
\text { diphenhydramine } 12.5 \mathrm{mg} \\
\text { Sumatriptan } 6 \mathrm{mg} \mathrm{SC} \\
\text { Single migraine attack }\end{array}$ & $\begin{array}{l}\text { The primary outcome measure was the mean change in pain } \\
\text { intensity from baseline to } 80 \text { minutes. The mean decrease in } \\
\text { pain intensity in the IV prochlorperazine with diphenhydramine } \\
\text { group was } 73 \mathrm{~mm} \text { compared with } 50 \mathrm{~mm} \text { in the subcutaneous } \\
\text { sumatriptan group. }\end{array}$ \\
\hline $\begin{array}{l}\text { Krymchantowski, } \\
\text { Filho, Bigal }{ }^{133}\end{array}$ & $\begin{array}{l}\text { Adults - mean age of } 39.7 \text { years } \\
n=32(75 \% \text { female and } 25 \% \\
\text { male) }\end{array}$ & $\begin{array}{l}\text { Rizatriptan } 10 \mathrm{mg} \text { tablet plus } \\
\text { trimebutine } 200 \mathrm{mg} \text { capsule } \\
\text { Rizatriptan } 10 \mathrm{mg} \\
\text { Placebo, } \\
\text { Two consecutive moderate or } \\
\text { severe attacks }\end{array}$ & $\begin{array}{l}\text { At } 1 \mathrm{~h} \text { postdose, } 30(46.8 \%) \text { of } 64 \text { attacks treated with the } \\
\text { combination resolved completely, vs. eight }(12.5 \%) \text { of the } \\
\text { rizatriptan-treated attacks, a difference of } 34 \% \text { ( }(P<0.01) \text {. At } \\
2 \mathrm{~h} \text { postdose, } 47 \text { ( } 73.4 \%) \text { attacks treated with the combination } \\
\text { vs. } 20(31.2 \% \text { ) of those treated with rizatriptan alone resolved } \\
\text { completely, a difference of } 42 \% \text { ( } 95 \% \text { confidence interval } 26,58 \text {, } \\
\mathrm{P}<0.001) \text {. Regarding nausea and photophobia, the combination } \\
\text { was also associated with significantly better response }\end{array}$ \\
\hline Lainez et al. ${ }^{134}$ & $\begin{array}{l}\text { Adults - almotriptan: } \\
33.15 \text { years ( } \pm 8.8 \text { years); } \\
\text { ergotamine+caffeine: } 33.84 \\
\text { years ( } \pm 10.1 \text { years) } \\
n=229 \text { (199 females and } 30 \\
\text { males) }\end{array}$ & $\begin{array}{l}\text { Almotriptan } 12.5 \mathrm{mg} \\
\text { Ergotamine } 2 \mathrm{mg} \text { plus caffeine } \\
200 \mathrm{mg} \\
\text { Treatment of two migraine } \\
\text { attacks }\end{array}$ & $\begin{array}{l}\text { Treatment with almotriptan was associated with a significantly } \\
\text { greater proportion of patients achieving } 2 \mathrm{~h} \text { pain-free }(20.9 \% \text { vs. } \\
13.7 \% \text {; } \mathrm{P}<0.05) \text { and } 2 \mathrm{~h} \text { pain relief }(57.7 \% \text { vs. } 44.5 \% ; \mathrm{P}<0.01) \\
\text { compared with ergotamine plus caffeine therapy; significant } \\
\text { differences were not seen at } 1 \mathrm{~h} \text {. Rates for sustained pain-free } \\
\text { and sustained pain-free plus no adverse events ( } \mathrm{AEs} \text { ) also were } \\
\text { significantly greater after almotriptan treatment than after the use } \\
\text { of ergotamine plus caffeine ( } \mathrm{P}<0.05) \text {. Almotriptan was associated } \\
\text { with a significantly lower rate of photophobia at } 90 \text { min }(\mathrm{P}<0.05) \text {, } \\
\text { phonophobia at } 60,90, \text { and } 120 \text { min }(\mathrm{P}<0.05 \text { to }<0.01) \text {, and } \\
\text { nausea and vomiting at } 90 \text { and } 120 \text { min }(\mathrm{P}<0.01) \text { compared } \\
\text { with ergotamine plus caffeine. } \\
\text { A significantly greater proportion of patients were more satisfied } \\
\text { with almotriptan ( } 55.7 \% \text { and } 64 \% \text {, } 1 \text { st and } 2 \text { nd attacks, } \\
\text { respectively) than with ergotamine plus caffeine (36\% and } \\
44.3 \%, 1 \text { st and } 2 \text { nd attacks, respectively) - ( } P<0.05) \text {. } \\
\text { Sixteen patients reported adverse events during almotriptan } \\
\text { treatment and } 27 \text { patients during the ergotamine plus caffeine } \\
\text { therapy. Most adverse events were mild-to-moderate and did not } \\
\text { result in treatment-related discontinuations. }\end{array}$ \\
\hline
\end{tabular}




\begin{tabular}{|c|c|c|c|}
\hline Landy et al. ${ }^{22}$ & $\begin{array}{l}\text { Adults }-37 \text { years }(37.8 \pm 8.5 \\
\text { years sumatriptan } 50 \mathrm{mg} ; \\
37.9 \pm 8.4 \text { years sumatriptan } \\
100 \mathrm{mg} ; 37.6 \pm 7.6 \text { placebo) } \\
\mathrm{n}=447 \text { (403 females and } 44 \\
\text { male) }\end{array}$ & $\begin{array}{l}\text { Sumatriptan } 50 \mathrm{mg} \text { tablets } \\
\text { Sumatriptan } 100 \mathrm{mg} \text { tablets } \\
\text { Placebo } \\
\text { Single migraine attack }\end{array}$ & $\begin{array}{l}\text { Sumatriptan } 50 \mathrm{mg} \text { and } 100 \mathrm{mg} \text { tablets were significantly more } \\
\text { effective than placebo at conferring pain-free response } 2 \mathrm{~h} \text { post- } \\
\text { dose ( }<0.001 \text { each sumatriptan group vs. placebo). The onset } \\
\text { of efficacy vs. placebo for pain-free response was observed by } \\
1 \mathrm{~h} \text { post-dose for sumatriptan } 100 \mathrm{mg}(\mathrm{p}<0.05) \text {. } \\
\text { Sustained freedom from pain from } 2 \text { through } 24 \mathrm{~h} \text { post-dose was } \\
\text { reported by } 30 \mathrm{and} 35 \% \text { of patients in the sumatriptan tablets } \\
50 \mathrm{mg} \text { and } 100 \mathrm{mg} \text { groups, respectively, compared with } 8 \% \text { of } \\
\text { placebo-treated patients ( } \mathrm{p}<0.001 \text { each sumatriptan group vs. } \\
\text { placebo). } \\
\text { Both doses of sumatriptan were well tolerated. The adverse events } \\
\text { were generally slightly higher in the sumatriptan groups than in } \\
\text { the placebo groups. }\end{array}$ \\
\hline Landy et al. ${ }^{22}$ & $\begin{array}{l}\text { Adults - mean age - } 37 \text { years - } \\
35.5 \pm 7.8 \text { years sumatriptan } 50 \\
\text { mg; } 37.3 \pm 8.7 \text { years sumatriptan } \\
100 \mathrm{mg} ; 36.9 \pm 7.6 \text { placebo; }) \\
\mathrm{n}=369 \text { ( } 349 \text { female and } 20 \\
\text { male) }\end{array}$ & $\begin{array}{l}\text { Sumatriptan } 50 \mathrm{mg} \text { tablets } \\
\text { Sumatriptan } 100 \mathrm{mg} \text { tablets } \\
\text { Placebo } \\
\text { Single migraine attack }\end{array}$ & $\begin{array}{l}\text { Sumatriptan } 50 \mathrm{mg} \text { and } 100 \mathrm{mg} \text { tablets were significantly more } \\
\text { effective than placebo at conferring pain-free response } 2 \mathrm{~h} \text { post- } \\
\text { dose ( } \mathrm{p}<0.001 \text { each sumatriptan group vs. placebo). The onset } \\
\text { of efficacy vs. placebo for pain-free response was observed by } \\
1 \mathrm{~h} \text { post-dose for sumatriptan } 100 \mathrm{mg} \text { ( } \mathrm{p}<0.05) \text {. Sumatriptan } \\
50 \mathrm{mg} \text { and } 100 \mathrm{mg} \text { tablets were } 30 \text { and } 31 \% \text { compared with } \\
14 \% \text { of placebo-treated patients ( } \mathrm{p}<0.05 \text { each sumatriptan } \\
\text { group vs. placebo). } \\
\text { Both doses of sumatriptan were well tolerated. The adverse events } \\
\text { were generally slightly higher in the sumatriptan groups than in } \\
\text { the placebo group. }\end{array}$ \\
\hline Lewis et al. ${ }^{135}$ & $\begin{array}{l}\text { Adults - mean age: } 14.2 \text { years } \\
\mathrm{n}=171 \text { ( } 98 \text { female and } 73 \\
\text { male) }\end{array}$ & $\begin{array}{l}\text { Zolmitriptan } 5 \text { mg nasal spray } \\
\text { Placebo } \\
\text { Crossover study 2-attacks }\end{array}$ & $\begin{array}{l}\text { The onset of significant pain relief was apparent } 15 \text { minutes after } \\
\text { treatment with zolmitriptan nasal spray. At } 1 \text { hour after the dose, } \\
\text { zolmitriptan nasal spray produced a higher headache response } \\
\text { rate than did placebo ( } 58.1 \% \text { vs } 43.3 \% \text { ). Zolmitriptan nasal spray } \\
\text { was also significantly superior to placebo in improvement in pain } \\
\text { intensity, pain-free rates, sustained resolution of headache, and } \\
\text { resolution of associated migraine symptoms. Return to normal } \\
\text { activities was also consistently faster with zolmitriptan nasal } \\
\text { spray than with placebo, with less use of any escape medication. } \\
\text { Treatment with zolmitriptan nasal spray was well tolerated. }\end{array}$ \\
\hline Linder et al. ${ }^{52}$ & $\begin{array}{l}\text { Adolescents - Placebo - } 14.4 \\
\text { (12-17) years; } \\
\text { Almotriptan } 6.25 \mathrm{mg}-14.4 \\
\text { (12-17) years; } \\
\text { Almotriptan } 12.5 \mathrm{mg} \cdot 14.2 \\
\text { (12-17) years; } \\
\text { Almotriptan } 25 \mathrm{mg}-14.4(12- \\
17) \text { years. } \\
\mathrm{n}=548 \text { ( } 227 \text { male and } 321 \\
\text { female) }\end{array}$ & $\begin{array}{l}\text { Almotriptan } 6.25 \mathrm{mg} \text { oral } \\
\text { Almotriptan } 12.5 \mathrm{mg} \text { oral } \\
\text { Almotriptan } 25 \mathrm{mg} \text { oral } \\
\text { Placebo } \\
1 \text { dose of study medication }\end{array}$ & $\begin{array}{l}\text { The } 2 \text {-hour pain-relief rate was significantly higher with almotriptan } \\
25 \text { mg compared with placebo ( } 66.7 \% \text { vs } 55.3 \% \text {; } P=.022) \text {. } \\
\text { The incidence of nausea, photophobia, and phonophobia at } 2 \\
\text { hours (adjusted for baseline pain intensity) for the almotriptan } \\
25 \text { mg and placebo groups was not significantly different. The } \\
2 \text {-hour pain-relief rates (unadjusted) were significantly higher with } \\
\text { almotriptan } 6.25 \mathrm{mg}(71.8 \%), 12.5 \mathrm{mg}(72.9 \%) \text {, and } 25 \mathrm{mg} \\
(66.7 \% \text { ) than with placebo }(55.3 \% ; \mathrm{P}=.001, \mathrm{P}<.001 \text {, and } \mathrm{P} \\
=0.028 \text {, respectively). } \\
\text { Rates for sustained pain relief also were significantly greater } \\
\text { with almotriptan } 6.25 \mathrm{mg}(67.2 \%), 12.5 \mathrm{mg}(66.9 \%) \text {, and } 25 \\
\text { mg (64.5\%) than with placebo group }(52.4 \%), \mathrm{P}<0.01 \text { for } \\
\text { the } 6.25-\text { and } 12.5 \text {-mg doses and P }<.05 \text { for the } 25 \text {-mg dose. } \\
\text { Age group subanalysis demonstrated significantly greater } 2 \text {-hour } \\
\text { pain relief rates with all } 3 \text { doses of almotriptan compared with } \\
\text { placebo for patients aged } 15 \text { to } 17 \text { years, a significantly lower } \\
\text { incidence of photophobia and phonophobia at } 2 \text { hours with } \\
\text { almotriptan } 12.5 \text { mg compared with placebo for patients } \\
\text { aged } 15 \text { to } 17 \text { years, and a significantly lower incidence of } \\
\text { photophobia with almotriptan } 12.5 \text { mg compared with placebo } \\
\text { for those aged } 12 \text { to } 14 \text { years. } \\
\text { Almotriptan treatment was well tolerated, with the most common } \\
\text { adverse events nausea, dizziness, and somnolence. }\end{array}$ \\
\hline $\begin{array}{l}\text { Lines, } \\
\text { Vandormael, } \\
\text { Malbecq }{ }^{136}\end{array}$ & $\begin{array}{l}\text { Adults - mean age } 40 \text { years } \\
n=872 \text { ( } 715 \text { female and } 157 \\
\text { male) }\end{array}$ & $\begin{array}{l}\text { Oral rizatriptan } 5 \mathrm{mg} \text {, } \\
\text { Oral sumatriptan } 50 \mathrm{mg} \\
\text { Placebo } \\
\text { Single migraine attack }\end{array}$ & $\begin{array}{l}\text { Active drugs were superior to placebo at reducing headache } \\
\text { pain and were similarly effective. }\end{array}$ \\
\hline Lipton et al. ${ }^{137}$ & $\begin{array}{l}\text { Adults - (mean age, } 38.1 \text { years) } \\
n=249 \text { (female } 86 \% \text { and male } \\
14 \% \text { ) }\end{array}$ & $\begin{array}{l}\text { Sumatriptan } 50 \text { mg tablets } \\
\text { Placebo } \\
\text { Series of } 5 \text { headaches }\end{array}$ & $\begin{array}{l}\text { Sumatriptan was superior to placebo for headache response } 4 \\
\text { hours postdose (primary endpoint) across all headache types } \\
\text { (migraine } 66 \% \text { versus } 48 \% ; \mathrm{P}<.001 \text {; migrainous } 71 \% \text { versus } \\
39 \% \text {; } \mathrm{P}<.01 \text {; tension-type } 78 \% \text { versus } 50 \% \text {, } \mathrm{P}<.001 \text { ). } \\
\text { Sumatriptan was also superior to placebo for pain-free response } \\
4 \text { hours postdose for migraine }(41 \% \text { versus } 24 \% \text {, } P<.001 \text { ) and } \\
\text { tension-type headaches }(56 \% \text { versus } 36 \%, P=.001) \text {. Sumatriptan } \\
\text { provided superior pain-free response } 2 \text { hours postdose for } \\
\text { migraine }(18 \% \text { versus } 7 \%, P<.0001 \text { ) and tension-type headache } \\
(28 \% \text { versus } 14 \%, P=.0005) \text { compared with placebo. }\end{array}$ \\
\hline Loder et al. ${ }^{138}$ & $\begin{array}{l}\text { Adults - mean age } 37.3 \text { years } \\
n=524 \text { ( } 429 \text { female and } 95 \\
\text { male) }\end{array}$ & $\begin{array}{l}\text { Rizatriptan ODT } 10 \mathrm{mg} \\
\text { Sumatriptan } 50 \mathrm{mg} \text { tablet } \\
\text { Two migraine attacks }\end{array}$ & $\begin{array}{l}\text { Percentage of patients who preferred rizatriptan ODT } 10-\mathrm{mg} \\
(57 \%, \mathrm{n}=213 \text { ) was significantly greater than those who preferred } \\
\text { sumatriptan } 50-\mathrm{mg} \text { tablet }(43 \%, \mathrm{n}=161)(\mathrm{P} .01) \text {. } \\
\text { A significantly greater percentage of patients reported pain relief } \\
\text { after taking rizatriptan ODT than sumatriptan at the } 45-\text { and } \\
60 \text {-minute time points ( } 38 \% \text { versus } 29 \% \text { and } 58 \% \text { versus } 49 \% \text {, } \\
\text { respectively) (P.01). In addition, a significantly greater percentage } \\
\text { of patients taking rizatriptan ODT reported a pain-free status at } \\
\text { the } 60 \text { - and } 120 \text {-minute time points ( } 23 \% \text { versus } 17 \% \text { [P.05] and } \\
60 \% \text { versus } 52 \% \text { [P.01], respectively). }\end{array}$ \\
\hline
\end{tabular}




\begin{tabular}{|c|c|c|c|}
\hline Loder et al. ${ }^{139}$ & $\begin{array}{l}\text { Adults - mean: } 37 \text { years range: } \\
18 \text { to } 55 \text { years [zolmitriptan: } \\
37.2 \pm 7.4 \text { (18-55) years and } \\
\text { placebo: } 37.9 \pm 7.2 \text { (19-51) } \\
\text { years] } \\
n=510 \text { (all female) }\end{array}$ & $\begin{array}{l}\text { Zolmitriptan } 2.5 \mathrm{mg} \text { oral } \\
\text { Placebo } \\
\text { in a series of } 5 \text { headaches }\end{array}$ & $\begin{array}{l}\text { A } 2 \text {-hour headache response was achieved in } 48 \% \text { of zolmitriptan- } \\
\text { treated attacks as compared with } 27 \% \text { of placebo-assigned } \\
\text { attacks ( } P<.0001) \text {. Zolmitriptan was superior to placebo in } \\
\text { achieving a headache response as early as } 30 \text { minutes }(18 \% \\
\text { versus } 14 \%, P=.03) \text { and at } 1 \text { hour }(33 \% \text { versus } 23 \%, P<.001) \text {. } \\
\text { Drug-related adverse events were reported in } 16 \% \text { of subjects } \\
\text { receiving zolmitriptan and } 9 \% \text { of subjects receiving placebo. }\end{array}$ \\
\hline Loder et al. ${ }^{140}$ & $\begin{array}{l}\text { Adults }-40.0 \pm 10.6 \\
\text { (Zolmitriptan } 2.5 \mathrm{mg}) ; 42.7 \pm \\
10.5 \text { (Placebo) } \\
\mathrm{n}=565 \text { ( } 482 \text { female and } 83 \\
\text { male) }\end{array}$ & $\begin{array}{l}\text { Zolmitriptan } 2.5 \mathrm{mg} \text { orally } \\
\text { disintegrating tablets (ODT) } \\
\text { Placebo } \\
\text { Patients treated up to } 2 \text { migraine } \\
\text { attacks }\end{array}$ & $\begin{array}{l}\text { Zolmitriptan } 2.5 \mathrm{mg} \text { ODT demonstrated a significant pain-free rate } \\
\text { vs. placebo at } 2 \mathrm{~h}(40 \% \text { vs. } 20 \%, \mathrm{p}<0.001), 1.5 \mathrm{~h} \text { ( }(25 \% \text { vs. } \\
15 \%, \mathrm{p}<0.001) \text {, and } 1 \mathrm{~h}(13 \% \text { vs. } 8 \%, \mathrm{p}=0.004) \text {. Sustained } \\
\text { pain-free rate was significantly higher than placebo ( } 31 \% \text { vs. } \\
15 \% \text {; } \mathrm{p}<0.001) \text {. } \\
\text { Significantly more patients treated with zolmitriptan } 2.5 \mathrm{mg} \text { ODT } \\
\text { were able to return to routine activities (work, school, or other } \\
\text { daily activities) when compared with placebo at } 1 \mathrm{~h}(\mathrm{p}=0.004) \text {, } \\
1.5 \mathrm{~h}(\mathrm{p}<0.001) \text {, and } 2 \mathrm{~h}(\mathrm{p}<0.001) \text {. } \\
\text { Zolmitriptan } 2.5 \mathrm{mg} \mathrm{ODT} \text { was well tolerated. Overall, } 33 \% \\
(92 / 282) \text { of patients treated with zolmitriptan } 2.5 \mathrm{mg} \text { ODT } \\
\text { experienced adverse events versus } 14 \%(41 / 284) \text { of placebo- } \\
\text { treated patients. The adverse events most commonly reported } \\
\text { in patients treated with zolmitriptan } 2.5 \text { mg ODT were those } \\
\text { commonly associated with the use of triptans, including dizziness, } \\
\text { somnolence, paresthesia, tightness, and asthenia. }\end{array}$ \\
\hline $\begin{array}{l}\text { Maghbooli et } \\
\text { al. }{ }^{141}\end{array}$ & $\begin{array}{l}\text { Adults } \\
\text { Ginger group }-33.9 \pm 8.3 \\
\text { Sumatriptan Group }-35.1 \pm \\
6.2 \\
\mathrm{n}=100(71 \text { female and } 29 \\
\text { male) }\end{array}$ & $\begin{array}{l}\text { Ginger } 250 \mathrm{mg} \text { powder capsule } \\
\text { Sumatriptan } 50 \mathrm{mg} \text { capsule } \\
\text { One capsulet upon headache } \\
\text { onset }\end{array}$ & $\begin{array}{l}\text { Frequency distribution of mean headache severity at } 2 \mathrm{~h} \text { after } \\
\text { drug use demonstrated similar effectiveness for sumatriptan and } \\
\text { ginger groups }(\mathrm{P}=0.116) \text {. } \\
\text { Comparing mean headache severity before and } 2 \mathrm{~h} \text { after } \\
\text { treatment revealed a } 4.7 \text { unit reduction (according to VAS) in } \\
\text { the sumatriptan group }(P<0.0001) \text { and a } 4.6 \text { unit reduction in } \\
\text { the ginger group }(P<0.0001) \text {. }\end{array}$ \\
\hline Mannix et al. ${ }^{23}$ & $\begin{array}{l}\text { Adults - mean age Rizatriptan - } \\
38 \text { years Placebo }-37 \text { years } \\
n=403 \text { (Female only) }\end{array}$ & $\begin{array}{l}\text { Rizatriptan } 10 \mathrm{mg} \text { tablet } \\
\text { Placebo } \\
\text { Single migraine attack }\end{array}$ & $\begin{array}{l}\text { The primary endpoint for efficacy analysis was pain relief at } 2 \mathrm{~h} \text {. } \\
2 \mathrm{~h} \text { pain relief - Rizatriptan } 70 \% \text { vs } 53 \% \text { placebo (OR } 2.11,95 \% \\
\mathrm{Cl} 1.34,3.32, \mathrm{P}=0.001 \text { ). } \\
24 \mathrm{~h} \text { Sustained pain relief - Rizatriptan } 46 \% \text { vs Placebo } 33 \% \text { (OR } \\
1.75,95 \% \mathrm{Cl} 1.11,2.77, \mathrm{P}=0.016) \text {. }\end{array}$ \\
\hline Mannix et al. ${ }^{23}$ & $\begin{array}{l}\text { Adults - Rizatriptan - } 37 \text { years; } \\
\text { Placebo - } 37.5 \\
n=399 \text { (Female only) }\end{array}$ & $\begin{array}{l}\text { Rizatriptan } 10 \mathrm{mg} \text { tablet } \\
\text { Placebo } \\
\text { Single migraine attack }\end{array}$ & $\begin{array}{l}\text { The primary endpoint for efficacy analysis was pain relief at } 2 \mathrm{~h} \text {. } \\
2 \mathrm{~h} \text { pain relief - Rizatriptan } 73 \% \text { vs Placebo - } 50 \% \text { (OR } 2.69,95 \% \\
\mathrm{Cl} 1.66,4.36, \mathrm{P}<0.001 \text { ). } \\
24 \mathrm{~h} \text { Sustained pain relief - Rizatriptan } 46 \% \text { vs Placebo } 33 \% \text { (OR } \\
1.74,95 \% \mathrm{Cl} 1.08,2.82, \mathrm{P}=0.024) \text {. }\end{array}$ \\
\hline Martínez et al. ${ }^{41}$ & $\begin{array}{l}\text { Adults - } 18 \text { to } 65 \text { years of age } \\
n=360 \text { ( } 271 \text { women and } 89 \\
\text { men) }\end{array}$ & $\begin{array}{l}\text { Metamizole }(0.5 \text { and } 1 \mathrm{~g}) \text { oral } \\
\text { Acetylsalicylic acid }(1 \mathrm{~g}) \text { oral } \\
\text { Placebo }\end{array}$ & $\begin{array}{l}\text { The pain intensity reduced steadily for all three active treatments } \\
\text { in comparison with placebo up to } 4 \mathrm{~h} \text { after administration. The } \\
\text { analgesic efficacy of } 0.5 \text { and } 1 \mathrm{~g} \text { metamizol vs placebo was } \\
\text { highly statistically significant for sum of pain intensity differences, } \\
\text { maximum pain intensity difference, number of patients with at } \\
\text { least } 50 \% \text { pain reduction, time to } 50 \% \text { pain reduction, maximum } \\
\text { pain relief and total pain relief. } \\
\text { A trend towards an earlier onset of a more profound pain relief of } \\
0.5 \text { and } 1 \mathrm{~g} \text { metamizol over } 1 \mathrm{~g} \text { Acetylsalicylic acid was noticed. } \\
\text { Adverse events were experienced during the treatment phase of } \\
\text { the study in all groups, but differences statistics were not observed. } \\
\text { Global assessment of tolerability by the patients was good or } \\
\text { satisfactory in more than } 90 \% \text { of all patients. }\end{array}$ \\
\hline Massiou et al. ${ }^{143}$ & $\begin{array}{l}\text { Adults - aged } 18 \text { to } 65 \text { years } \\
n=257 \text { (Female only) }\end{array}$ & $\begin{array}{l}\text { Naratriptan } 2.5 \mathrm{mg} \\
\text { Placebo } \\
\text { single migraine attack }\end{array}$ & $\begin{array}{l}\text { A higher percentage of subjects in the naratriptan group }(58 \%) \\
\text { reported complete pain relief } 4 \mathrm{~h} \text { after medication than in } \\
\text { the placebo group }(30 \%)(P<0.001) \text {. Significant differences } \\
\text { between the naratriptan and placebo groups and in favor of } \\
\text { naratriptan were also found for: total pain relief at } 2 \mathrm{~h}(\mathrm{P}= \\
0.004) \text {, sustained pain-free response within } 4-24 \mathrm{~h}(\mathrm{P}<0.001) \text {, } \\
\text { absence of all associated symptoms at } 2 \text { and } 4 \mathrm{~h}(\mathrm{P}=0.004) \text {, } \\
\text { ability to work and carry out daily activities at } 2 \mathrm{~h}(\mathrm{P}=0.036) \text {, } \\
\text { and patient overall satisfaction }(\mathrm{P}<0.001) \text {. }\end{array}$ \\
\hline Mathew et al. ${ }^{144}$ & $\begin{array}{l}\text { Adults - mean age } 41.2 \text { years } \\
(\mathrm{SD}=9.6) \\
\mathrm{n}=682(614 \text { female and } 68 \\
\text { male) }\end{array}$ & $\begin{array}{l}\text { Naratriptan tablet } 2.5,1 \text { and } \\
0.25 \mathrm{mg} \\
\text { Placebo } \\
\text { Treat } 4 \text { migraine attacks }\end{array}$ & $\begin{array}{l}\text { Headache relief } 4 \text { hours postdose occurred in } 68 \% \\
\text { naratriptan } 2.5 \mathrm{mg} \text { vs } 57 \% \text { naratriptan } 1.0 \mathrm{mg} \text { vs } 3 \% \\
\text { naratriptan } 0.25 \mathrm{mg} \text { vs } 33 \% \text { placebo ( }<0.001 \\
\text { naratriptan } 2.5 \mathrm{mg} \text { and } 1 \mathrm{mg} \text { versus placebo or } 0.25 \mathrm{mg} \text { ). } \\
\text { Headache was eliminated } 4 \text { hours postdose }-45 \% \text { naratriptan } \\
2.5 \mathrm{mg} \text { vs } 33 \% \text { naratriptan } 1 \mathrm{mg}, 20 \% \text { naratriptan } 0,25 \mathrm{mg} \text { and } \\
15 \% \text { placebo }(\mathrm{p}<0.001 \text { naratriptan } 2.5 \mathrm{mg} \text { and } 1 \mathrm{mg} \text { versus } \\
\text { placebo or } 0.25 \mathrm{mg}) \text {. }\end{array}$ \\
\hline
\end{tabular}




\begin{tabular}{|c|c|c|c|}
\hline Mathew et al. ${ }^{145}$ & $\begin{array}{l}\text { Adults - aged to } 18 \text { to } 65 \\
\text { Eletriptan } 40 \mathrm{mg}-41.1(10.8) \\
\text { Sumatriptan }-41.8(10.4) \\
\text { Placebo }-41.6(10.6) \\
\mathrm{n}=2,072 \text { (Female } 1795 \text { and } \\
277 \text { male) }\end{array}$ & $\begin{array}{l}\text { Eletriptan } 40 \mathrm{mg} \text { tablet } \\
\text { Sumatriptan } 100 \mathrm{mg} \text { capsules } \\
\text { Placebo } \\
\text { Single migraine attack }\end{array}$ & $\begin{array}{l}\text { Headache response rates at } 2 \text { hours postdose were significantly } \\
\text { higher for eletriptan } 40 \mathrm{mg}(67 \%) \text { than for sumatriptan } 100 \mathrm{mg} \\
(59 \% ; \mathrm{P} .001) \text { and placebo }(26 \% ; \mathrm{P} .0001) \text {. } \\
\text { Eletriptan } 40 \mathrm{mg} \text { consistently showed significant (P .01) efficacy } \\
\text { over sumatriptan } 100 \mathrm{mg} \text { across secondary clinical outcomes, } \\
\text { including } 1 \text {-hour headache response; } 2 \text {-hour pain-free response; } \\
\text { absence of nausea, photophobia, and phonophobia; functional } \\
\text { improvement; use of rescue medication; treatment acceptability; } \\
\text { and sustained headache response }(P<0.05) \text {. Overall, treatment- } \\
\text { related adverse events were low. }\end{array}$ \\
\hline $\begin{array}{l}\text { Mathew, } \\
\text { Kailasam, } \\
\text { Meadors }^{146}\end{array}$ & $\begin{array}{l}\text { Rizatripitan } 10 \mathrm{mg}-39.0 \pm 9.5 \\
\text { years; } \\
\text { Placebo }-42.0 \pm 7.2 \text { years. } \\
\mathrm{n}=112(103 \text { female and } 9 \\
\text { male) }\end{array}$ & $\begin{array}{l}\text { Rizatriptan } 10 \mathrm{mg} \text { tablets } \\
\text { Placebo } \\
\text { Three migraine attacks }\end{array}$ & $\begin{array}{l}\text { Pain-free response at } 2 \text { hours after early treatment was noted in } \\
70 \% \text { of attacks in the rizatriptan group and in } 22 \% \text { in the placebo } \\
\text { group }(P<.01) \text {. Pain-free response at } 1 \text { hour occurred in } 45 \% \\
\text { and } 8 \% \text { attacks, respectively }(P<.01) \text {. When the attacks were } \\
\text { categorized by headache severity at the time of treatment, the } \\
\text { pain-free response at } 2 \text { hours was higher for mild attacks than } \\
\text { for moderate or severe attacks }(P<.01) \text {. } \\
\text { Sustained pain-free response after treatment was significantly } \\
\text { higher for attacks treated with rizatriptan }(60 \%) \text { than for those } \\
\text { treated with placebo }(17 \%)(P<.001) \text {. Adverse events were } \\
\text { reported in } 62 \text { attacks }(29 \%) \text { in the rizatriptan group and } 15 \\
\text { attacks }(14 \%) \text { in the placebo group. }\end{array}$ \\
\hline Mathew et al. ${ }^{147}$ & $\begin{array}{l}\text { Adults - mean age } 40.4 \text { years } \\
\mathrm{n}=378 \text { ( } 328 \text { female and } 50 \\
\text { male) }\end{array}$ & $\begin{array}{l}\text { Almotriptan } 12.5 \mathrm{mg} \text { tablet } \\
\text { Placebo } \\
\text { Consecutive } 3 \text { migraine attacks }\end{array}$ & $\begin{array}{l}\text { Pain free at } 2 \text { hours portdose for the } 1 \text { st headache - (Almotriptan } \\
37 \% \text { vs Placebo } 23.9 \% p=0,010 \text { ). } \\
2 \text {-hour pain relief (Almotriptan } 59.9 \% \text { vs Placebo } 42.6 \% p<0.001 \text { ) } \\
\text { and modified } 2 \text {-hour pain relief (Almotriptan } 59.9 \% \text { vs Placebo } \\
42.6 \% p<0.001 \text { ). } \\
\text { Significant differences in pain free, pain relief and modified } \\
\text { pain relief between almotriptan and placebo was also observed } \\
\text { at } 1 \text { hour. }\end{array}$ \\
\hline McGinley et al. ${ }^{148}$ & $\begin{array}{l}\text { Adults - mean age } 40.0 \text { ( } 12.3) \\
\text { years. } \\
n=259 \text { ( } 84.6 \% \text { female and } \\
15.4 \% \text { male) }\end{array}$ & $\begin{array}{l}\text { Sumatriptan } 22 \mathrm{mg} \text { nasal } \\
\text { powder } \\
\text { Sumatriptan } 100 \mathrm{mg} \text { tablets } \\
\text { Treat up to } 5 \text { attacks }\end{array}$ & $\begin{array}{l}\text { The primary outcomes for these analyses were migraine pain } \\
\text { intensity and migraine related disability. Average pain intensity } \\
\text { for Sumatriptan } 22 \text { mg nasal treated attacks was significantly } \\
\text { lower than sumatriptan treated ones at all time points from } 10 \\
\text { to } 90 \text { minutes ( } P<.05 \text { for all). } \\
\text { portion of the models showed that Sumatriptan } 22 \text { mg nasal had } \\
\text { significantly lower disability from } 10 \text { to } 90 \text { minutes. }\end{array}$ \\
\hline $\begin{array}{l}\text { Meredith, Wait, } \\
\text { Brewer'149 }\end{array}$ & $\begin{array}{l}\text { Adults - mean age of } 33 \text { years } \\
\text { ( } 18-54 \text { years) } \\
n=29 \text { ( } 4 \text { male and } 25 \text { female) }\end{array}$ & $\begin{array}{l}\text { Sumatriptan } 20 \text { mg nasal } \\
\text { Ketorolac } 30 \text { mg intravenous } \\
\text { Sigle migraine attack }\end{array}$ & $\begin{array}{l}\text { Patients scored the severity of their headache on a } 100-\mathrm{mm} \\
\text { visual analog scale (VAS) of pain prior to medication and again } \\
1 \text { hour after medication. Differences between initial and } 1 \text {-hour } \\
\text { scores were analyzed. Before treatment, no difference existed } \\
\text { between the groups in the intensity of headache. One hour after } \\
\text { medication, the sumatriptan group had a decrease in pain score } \\
\text { of } 22.937 \mathrm{~mm} \text { and the ketorolac group a decrease of } 71.462 \\
\mathrm{~mm} \text { on the VAS. The decrease in pain score with ketorolac was } \\
\text { significantly greater than that with sumatriptan ( }<0.001) \text {. }\end{array}$ \\
\hline Miljkovic et al. ${ }^{150}$ & $\begin{array}{l}\text { Adults - } 18 \text { to } 64 \text { years } \\
n=201 \text { ( } 168 \text { female and } 33 \\
\text { male) }\end{array}$ & $\begin{array}{l}\text { Sumatriptan tablet } \\
\text { Ergotamine combination tablet } \\
\text { (propyphenazone, caffeine, } \\
\text { camylofin chloride, mecloxamine } \\
\text { citrate) } \\
\text { Placebo }\end{array}$ & $\begin{array}{l}\text { Higher percentage of patients was completely free of the } \\
\text { headache } 2 \text { hours after dose administration in the ergotamine- } \\
\text { based medication group compared to the sumatriptan group, } \\
\text { regardless whether all ( } 51.12 \% \text { vs } 33.70 \% \text { ) or only repeated } \\
\text { attacks were taken into account (50.91\% vs } 23.73 \% \text { ). The } \\
\text { salvage therapy (diclofenac) utilization rate was also lower in } \\
\text { the ergotamine-based medication group (relative risk } 0.61) \text {. }\end{array}$ \\
\hline Misra et al. ${ }^{151}$ & $\begin{array}{l}\text { Adults - mean age of } 32.6 \pm \\
2.57 \text { years. } \\
n=40 \text { (Female } 27 \text { and Male 13) }\end{array}$ & $\begin{array}{l}\text { Naproxen } 500 \mathrm{mg} \\
\text { Sumatriptan } 50 \mathrm{mg} \\
\text { Rizatriptam } 10 \mathrm{mg} \\
\text { Ergotamine tartrate }(2 \mathrm{mg})+ \\
\text { caffeine }(100 \mathrm{mg})+\text { cyclizine } \\
\mathrm{HCL}(50 \mathrm{mg}) \\
\text { Single dose during migraine } \\
\text { attack }\end{array}$ & $\begin{array}{l}\text { Naproxen, rizatriptan and sumatriptan were better than } \\
\text { ergotamine in causing freedom from the associated symptoms } \\
\text { of nausea, vomiting, photophobia and phonophobia at } 2 \text {-hour } \\
\text { postdose. Naproxen, rizatriptan and sumatriptan were also } \\
\text { efficacious in causing functional normalization at } 2 \text { hours } \\
\text { postdose as compared to ergotamine. }\end{array}$ \\
\hline $\begin{array}{l}\text { Misra, Kalita, } \\
\text { Yadav }^{152}\end{array}$ & $\begin{array}{l}\text { Adults - Rizatriptan } 29.15 \pm 8.7 \text {, } \\
\text { lbuprofen } 30.5 \pm 10.6 \text { and } \\
\text { control } 31.78 \pm 9.9 \text { years } \\
\mathrm{n}=155 \text { (female } 114 \text { and } 41 \\
\text { male) }\end{array}$ & $\begin{array}{l}\text { Rizatriptan } 10 \mathrm{mg} \text {, } \\
\text { lbuprofen } 400 \mathrm{mg} \\
\text { Placebo } \\
\text { Single migraine attack }\end{array}$ & $\begin{array}{l}\text { Efficacy was assessed by headache relief and headache freedom } \\
\text { at } 2 \mathrm{~h} \text { and } 24 \mathrm{~h} \text {. Two-hour headache relief was noted in } 73 \% \\
\text { in rizatriptan, } 53.8 \% \text { in ibuprofen and } 8 \% \text { in placebo groups. } \\
\text { Headache freedom was achieved in } 37.7 \% \text { in rizatriptan, } 30.8 \% \\
\text { in ibuprofen and } 2 \% \text { in placebo groups. }\end{array}$ \\
\hline Monda et al. ${ }^{153}$ & $\begin{array}{l}\text { Adults }-34,6 \text { years (SD 9,6) } \\
n=101 \text { (73 female and } 28 \\
\text { male) }\end{array}$ & $\begin{array}{l}\text { Indomethacin } 25 \mathrm{mg}+ \\
\text { prochlorperazine } 4 \mathrm{mg} \text { and } \\
\text { caffeine } 75 \mathrm{mg} \text { suppository } \\
\text { Sumatriptan } 25 \mathrm{mg} \text { suppository } \\
\text { Treatment of } 4 \text { consecutive } \\
\text { migraine attacks }\end{array}$ & $\begin{array}{l}\text { Pain-free at } 2 \text { hours postdose - Indomethacin } 25 \mathrm{mg}+ \\
\text { prochlorperazine } 4 \mathrm{mg} \text { and caffeine } 75 \mathrm{mg} \text { suppository } \\
\text { was superior to sumatriptan in the second attack }(52 \% \text { versus } \\
33 \% ; \mathrm{P}<.05 \text { ) and in the total attacks ( } 49 \% \text { versus } 34 \% ; \mathrm{P}<.01 \\
\text { ). } \\
\text { time to a pain-free response was significantly }(\mathrm{P}<.05 \text { ) higher } \\
\text { with Indomethacin } 25 \mathrm{mg}+\text { prochlorperazine } 4 \mathrm{mg} \text { and caffeine } \\
75 \mathrm{mg} \text { suppository than with sumatriptan in the first, second, and } \\
\text { total attacks. Headache relief rates in the total attacks at } 2 \text { hours } \\
\text { postdose were } 71 \% \text { with Indomethacin } 25 \mathrm{mg}+\text { prochlorperazine } \\
4 \mathrm{mg} \text { and caffeine } 75 \mathrm{mg} \text { suppository and } 65 \% \text { with sumatriptan, } \\
\text { without any statistically significant difference between the drugs. }\end{array}$ \\
\hline
\end{tabular}




\begin{tabular}{|c|c|c|c|}
\hline Moon et al. ${ }^{154}$ & $\begin{array}{l}\text { Adults - aged } 18 \text { to } 65 \text { years } \\
\text { - frovatriptan: } 36.75 \pm 10.23 \\
\text { years; placebo: } 38.07 \pm 9.22 \\
\text { years. } \\
\text { n=229 (207 females and } 22 \\
\text { males) }\end{array}$ & $\begin{array}{l}\text { Frovatriptan } 2.5 \mathrm{mg} \\
\text { Placebo }\end{array}$ & $\begin{array}{l}\text { Frovatriptan significantly increased the } 2 \text {-hour headache response } \\
\text { rate compared with placebo }(52.9 \% \text { vs. } 34.0 \%, p=0.004) \text {. The } \\
\text { headache response rates at } 4,6 \text {, and } 12 \text { hours were significantly } \\
\text { higher in the frovatriptan group than in the placebo group, as } \\
\text { was the pain-free rate at } 2 \text { hours }(19.0 \% \text { vs. } 5.7 \%, p=0.004) \text {, } \\
4 \text { hours }(40.7 \% \text { vs. } 23.0 \%, p=0.006) \text {, and } 6 \text { hours }(56.1 \% \text { vs. } \\
34.0 \%, p=0.002) \text {. } \\
\text { The median time to a headache response was significantly shorter } \\
\text { in the frovatriptan group than in the placebo group ( } 2.00 \text { hours } \\
\text { vs. } 3.50 \text { hours, } p<0.001) \text {. } \\
\text { The use of rescue medications was more common in the placebo } \\
\text { group }(p=0.005) \text {. }\end{array}$ \\
\hline $\begin{array}{l}\text { Moshtaghion et } \\
\text { al. }{ }^{15}\end{array}$ & $\begin{array}{l}\text { Adults - sumatriptan group } \\
33.36+7.91 \text { and Propotol } \\
\text { group } 33.08+8.12 \text { years } \\
\mathrm{n}=90 \text { (68 female and } 22 \text { male) }\end{array}$ & $\begin{array}{l}\text { Sumatriptan } 6 \mathrm{mg} \mathrm{SC} \\
\text { Propofol IV in } 30 \text { to } 40 \mathrm{mg} \\
\text { bolus } \\
\text { Single migraine attack }\end{array}$ & $\begin{array}{l}\text { Pain intensity was significantly lower in the propofol group } 30 \\
\text { minutes after treatment }(P=0.001) \text {; however, after } 1 \text { and } 2 \\
\text { hours, there were no significant differences between the groups. } \\
\text { The need for antiemetic therapy and the recurrence of symptoms } \\
\text { were significantly lower in the propofol group ( } P=0.045 \text { and } P \\
=0.001 \text {, respectively). }\end{array}$ \\
\hline Muller, Lohse ${ }^{156}$ & $\begin{array}{l}\text { Adults } \text { - Men }=45.31 \pm 13.89 \\
\text { years; Women }=41.98 \pm \\
12.54 \text { years } \\
n=57(13 \text { male and } 44 \text { female })\end{array}$ & $\begin{array}{l}\text { Parecoxib } 40 \mathrm{mg} \text { infusion } \\
\text { Sumatriptan (6 mg/0.5 mL) } \\
\text { Rizatriptan ODT } 10 \mathrm{mg} \\
\text { Single migraine attack }\end{array}$ & $\begin{array}{l}\text { Rizatriptan decreased pain intensity } 20 \text { minutes after intake, } \\
\text { ( } 44.33 \text {; } P<0.0001 \text {; post hoc analysis) more than parecoxib } \\
\text { and sumatriptan, but parecoxib was more efficacious than } \\
\text { sumatriptan. At } 30 \text { minutes after drug application, rizatriptan } \\
\text { was superior ( } 26.51 \text {; } P<0.0001 \text {; post hoc analysis) to parecoxib } \\
\text { and sumatriptan, but parecoxib showed a better effect on pain } \\
\text { symptoms than sumatriptan. }\end{array}$ \\
\hline Mushet et al. ${ }^{24}$ & $\begin{array}{l}\text { Adults - } 40 \text { ( } 18 \text { to } 65) \text { years } \\
\text { (sumatriptan }-40.4 \text { years and } \\
\text { placebo - } 37.9 \text { years) } \\
\mathrm{n}=80 \text { ( } 69 \text { female and } 11 \\
\text { males) }\end{array}$ & $\begin{array}{l}\text { Sumatriptan } 6 \text { mg SC } \\
\text { Placebo } \\
\text { Single migraine attack }\end{array}$ & $\begin{array}{l}\text { By } 120 \text { minutes after SC dosing, } 73 \% \text { of sumatriptan-treated } \\
\text { patients compared with } 28 \% \text { of placebo-treated experienced } \\
\text { headache relief ( } \mathrm{P} \leq 0.05) \text {. Clinical disability scores } 120 \text { minutes } \\
\text { after dosing showed that } 75 \% \text { of sumatriptan-treated patients, } \\
\text { compared with } 30 \% \text { of placebo-treated patients, were normal } \\
\text { or only mildly impaired ( } \mathrm{P} \leq 0.05) \text {. Similar efficacy rates were } \\
\text { observed for nausea, phonophobia, and photophobia. No } \\
\text { serious or unusual adverse events occurred, and no clinically } \\
\text { relevant abnormalities in laboratory test values were reported. }\end{array}$ \\
\hline Mushet et al. ${ }^{24}$ & $\begin{array}{l}\text { Adults - } 40 \text { ( } 18 \text { to } 65) \text { years: } \\
\text { sumatiptan: } 40.2 \text { years; } \\
\text { placebo: } 40.2 \text { years. } \\
n=78 \text { ( } 10 \text { males and } 68 \\
\text { females) }\end{array}$ & $\begin{array}{l}\text { Sumatriptan } 6 \text { mg SC } \\
\text { Placebo } \\
\text { Single migraine attack }\end{array}$ & $\begin{array}{l}\text { By } 120 \text { minutes after SC dosing, } 79 \% \text { of sumatriptan-treated } \\
\text { patients, compared with } 37 \% \text { of placebo-treated patients } \\
\text { experienced headache relief ( } P \leq 0.05 \text { ). Clinical disability scores } \\
120 \text { minutes after dosing showed that } 85 \% \text { of sumatriptan-treated } \\
\text { patients, compared with } 42 \% \text { of placebo-treated patients, were } \\
\text { normal or only mildly impaired ( } \mathrm{P} \leq 0.05) \text {. } \\
\text { Similar efficacy rates were observed for nausea, phonophobia, } \\
\text { and photophobia. No serious or unusual adverse events occurred, } \\
\text { and no clinically relevant abnormalities in laboratory test values } \\
\text { were reported. }\end{array}$ \\
\hline Myllylä et al. ${ }^{157}$ & $\begin{array}{l}\text { Adults - Tolfenamic Acid Rapid } \\
\text { Release - } 39 \pm 8.3 \text { years; } \\
\text { Placebo }-39 \pm 9.5 \text { years; } \\
\text { Sumatriptan }-40 \pm 10.0 \text { years. } \\
\text { n= } 140 \text { ( } 126 \text { female and } 14 \\
\text { male) }\end{array}$ & $\begin{array}{l}\text { Tolfenamic acid rapid release } \\
\text { tablets } 200 \mathrm{mg} \\
\text { Sumatriptan } 100 \mathrm{mg} \text { oral } \\
\text { Placebo } \\
\text { Two successive migraine attacks. }\end{array}$ & $\begin{array}{l}\text { For first attack, } 77 \% \text { of patients receiving tolfenamic acid } \\
\text { experienced a reduction of the initial severe or moderate } \\
\text { headache to mild or no headache after } 2 \text { hours, as compared } \\
\text { to } 79 \% \text { in the sumatriptan group and } 29 \% \text { in the placebo group. } \\
\text { No significant difference was found between active treatments ( } \\
=0.85,95 \% \mathrm{Cl}[-22 \%, 18 \%] \text { ), however, both active treatments } \\
\text { were significantly better than placebo; } \mathrm{P}=0.001,95 \% \mathrm{Cl}(26 \% \text {, } \\
69 \% \text { ) for tolfenamic acid and } \mathrm{P}=0.001,95 \% \mathrm{Cl}(28 \%, 71 \%) \\
\text { for sumatriptan. } \\
\text { For second attack, results were similar with } 70 \% \text { of patients } \\
\text { receiving tolfenamic acid experiencing relief, as compared to } \\
64 \% \text { in the sumatriptan group and } 39 \% \text { in the placebo group. } \\
\text { No significant differences were observed in accompanying } \\
\text { symptoms. Both drugs were well tolerated with the frequency of } \\
\text { adverse events; } 30 \% \text { for tolfenamic acid and } 41 \% \text { for sumatriptan } \\
\text { (nonsignificant difference). }\end{array}$ \\
\hline Nappi et al. ${ }^{158}$ & $\begin{array}{l}\text { Adults - } 18 \text { and } 65 \text { year; mean } \\
\text { age } 38(11) \text { placebo and } \\
\text { Sumatriptan } 38(9) \text {. } \\
n=244 \text { ( } 188 \text { female and } 56 \\
\text { male) }\end{array}$ & $\begin{array}{l}\text { Sumatriptan } 100 \mathrm{mg} \text { tablet } \\
\text { Placebo } \\
\text { First dose at the earliest sign of } \\
\text { migraine }\end{array}$ & $\begin{array}{l}\text { Sumatriptan was significantly more effective than placebo at } \\
\text { relieving headache (defined as reduction in severity from severe } \\
\text { or moderate pain to mild or no pain) at } 2 \mathrm{~h}(51 \% \text { versus } 31 \%, \mathrm{P} \\
=0.003) \text { and } 4 \mathrm{~h}(71 \% \text { versus } 35 \%, \mathrm{P}<0.001) \text {. } \\
\text { Fewer sumatriptan-treated patients required a second dose } \\
\text { compared with placebo-treated patients ( } 49 \% \text { versus } 74 \%, \mathrm{P}< \\
0.001) \text {. More sumatriptan treated patients were completely pain } \\
\text { free compared with placebo-treated patients at both } 2 \mathrm{~h} \text { ( } 24 \% \\
\text { versus } 12 \% \text { ) and } 4 \mathrm{~h}(48 \% \text { versus } 18 \%) \text {. }\end{array}$ \\
\hline Nett et al. ${ }^{159}$ & $\begin{array}{l}\text { Adults } \text { - Placebo }=36.8 \pm 7.7 \\
\text { Sumatriptan } 50 \mathrm{mg}=35.3 \pm \\
\text { 7.8; Sumatriptan } 100 \mathrm{mg}=37.1 \\
\pm 8.8 \text {. } \\
\mathrm{n}=349 \text { (Female only) }\end{array}$ & $\begin{array}{l}\text { Sumatriptan } 50 \text { and } 100 \\
\text { mg tablet } \\
\text { Placebo } \\
\text { Single menstrually } \\
\text { associated migraine }\end{array}$ & $\begin{array}{l}\text { Sumatriptan was superior to placebo in providing patients with } \\
\text { pain-free relief at } 2 \text { hours. } \\
\text { Pain-free relief at } 2 \text { hours - sumatriptan } 100 \mathrm{mg}(61 \%) \text { and } \\
\text { sumatriptan } 50 \mathrm{mg}(51 \%) \text { compared with the placebo (29\%) (both } \\
\mathrm{P}<0.001) \text {. } \\
\text { pain-free-Sumatriptan } 100 \mathrm{mg}(31 \%) \text { and } 50 \mathrm{mg}(30 \%) \text { compared } \\
\text { with Placebo ( } 14 \%)(100 \mathrm{mg} \text { versus placebo } \mathrm{P}=0.004 ; 50 \mathrm{mg} \\
\text { versus placebo } \mathrm{P}=.007) \text {. }\end{array}$ \\
\hline
\end{tabular}




\begin{tabular}{|c|c|c|c|}
\hline Newman et al. 160 & $\begin{array}{l}\text { Adults - Naratriptan } 2.5 \mathrm{mg}- \\
36.3 \\
\text { Naratriptan } 1 \mathrm{mg}-38 \\
\text { Placebo }-36.4 \\
\mathrm{n}=206 \text { (all female) }\end{array}$ & $\begin{array}{l}\text { Naratriptan } 1 \text { and } 2.5 \mathrm{mg} \text { oral } \\
\text { Placebo } \\
\text { Menstrual associated } \\
\text { migraine }\end{array}$ & $\begin{array}{l}\text { Headache-free Naratriptan } 1 \mathrm{mg} 50 \% \text { versus Placebo } 25 \% \text {, } \\
(\mathrm{P}=.003) \text {. More patients treated with naratriptan } 1 \mathrm{mg} \text { were } \\
\text { headache free compared with placebo ( } 23 \% \text { versus } 8 \%) \text {, } \\
\text { although statistical tests were not performed. } \\
\text { Significantly more patients treated with naratriptan } 1 \mathrm{mg} \text { reported } \\
\text { menstrual associated migraine } 50 \% \text { or less compared with } \\
\text { placebo-treated patients. Patients treated with naratriptan } 1 \mathrm{mg} \text {, } \\
\text { also had significantly fewer menstrual associated migraine days } \\
\text { compared with placebo-treated patients. }\end{array}$ \\
\hline $\begin{array}{l}\text { The Finnish } \\
\text { Sumatriptan } \\
\text { Group and the } \\
\text { Cardiovascular } \\
\text { Clinical Research } \\
\text { Group }^{161}\end{array}$ & $\begin{array}{l}\text { Adults - } 18-60 \text { years } \\
\text { [sumatriptan: } 38 \pm 10 \text {; placebo: } \\
40 \pm 9 ;] \\
\mathrm{n}=744^{\prime}(11 \text { male and } 63 \text { female) }\end{array}$ & $\begin{array}{l}\text { Sumatriptan (insufflation } 20 \text { mg } \\
\text { plus } 20 \mathrm{mg} \text { ) Intranasal } \\
\text { Placebo }\end{array}$ & $\begin{array}{l}\text { Sumatriptan ( } 20 \text { mg plus } 20 \mathrm{mg} \text { ) was more effective than placebo } \\
\text { at relieving headache, defined as reduction in severity from } \\
\text { moderate or severe to mild or none, at } 60 \text { and } 120 \text { min. At } \\
120 \text { min, } 75 \% \text { of patients in the sumatriptan group reported } \\
\text { headache relief, compared with } 32 \% \text { of patients in the placebo } \\
\text { group ( } p<0.001) \text {; } 53 \% \text { of patients in the sumatriptan group were } \\
\text { completely pain-free compared with } 11 \% \text { in the placebo group. } \\
\text { Nausea incidence was significantly lower in sumatriptan } \\
\text { group compared with placebo at both } 60 \text { min ( } 17 \text { vs. } 43 \% \text {; } \\
p=0.014 \text { ) and } 120 \text { min ( } 14 \text { vs. } 38 \% ; p=0.021 \text { ). Photophobia } \\
\text { was significantly lower in sumatriptan group, compared with } \\
\text { placebo at } 60 \text { min ( } 28 \text { vs. } 57 \% ; p=0.013 \text { ) and } 120 \text { min ( } 19 \text { vs. } \\
51 \% ; p=0.005) \text {. } \\
\text { Sumatriptan was significantly more effective at reducing functional } \\
\text { disability of patients at } 30 \text { min ( } p=0.024 \text { ) and at } 60 \text { and } 120 \\
\text { min ( } p<0.001 \text { ). However, similar number of patients reported } \\
\text { migraine recurrence, within } 24 \mathrm{~h} \text { in both treatment groups. }\end{array}$ \\
\hline $\begin{array}{l}\text { The Subcutaneous } \\
\text { Sumatriptan } \\
\text { International } \\
\text { Study Group }\end{array}$ & $\begin{array}{l}\text { Adults - }(41 \pm 11 \text { years } \\
\text { sumatriptan } 6 \mathrm{mg} ; 40 \pm 11 \text { years } \\
\text { sumatriptan } 8 \mathrm{mg} ; 39 \pm 11 \text { years } \\
\text { placebo) } \\
\mathrm{n}=639 \text { (521 females and } 118 \\
\text { males) }\end{array}$ & $\begin{array}{l}\text { Sumatriptan } 6 \text { or } 8 \mathrm{mg} \mathrm{SC} \\
\text { Placebo }\end{array}$ & $\begin{array}{l}\text { After } 60 \text { minutes, the severity of headache was decreased in } 72 \% \\
\text { of the } 422 \text { patients given } 6 \mathrm{mg} \text { of sumatriptan, } 79 \% \text { of the } 109 \\
\text { patients given } 8 \mathrm{mg} \text { of sumatriptan, and } 25 \% \text { of the } 105 \text { patients } \\
\text { given placebo. As compared with the placebo group, } 47 \% \text { more } \\
\text { patients who had received } 6 \mathrm{mg} \text { of sumatriptan and } 54 \% \text { more } \\
\text { patients who had received } 8 \mathrm{mg} \text { of sumatriptan had a decrease } \\
\text { in the severity of headache ( } P<0.001 \text { for both comparisons). } \\
\text { After } 120 \text { minutes, } 86 \text { to } 92 \% \text { of the } 511 \text { patients treated with } \\
\text { sumatriptan had improvement in the severity of headache, as } \\
\text { compared with only } 37 \% \text { of the } 104 \text { patients who received } \\
\text { placebo once or twice ( }(P<0.001 \text { for all comparisons). }\end{array}$ \\
\hline $\begin{array}{l}\text { The Multinational } \\
\text { Oral Sumatriptan } \\
\text { and Cafergot } \\
\text { Comparative } \\
\text { Study Group }\end{array}$ & $\begin{array}{l}\text { Adults - mean age: } 39.5 \text { years } \\
\text { [sumatriptan: } 39 \pm 10 \text { years; } \\
\text { cafergot: } 40 \pm 10 \text { years;] } \\
n=577 \text { ( } 98 \text { males and } 479 \\
\text { females) }\end{array}$ & $\begin{array}{l}\text { Sumatriptan } 100 \mathrm{mg} \text { oral } \\
\text { Cafergot (ergotamine tartrate } 2 \\
\text { mg + caffeine } 200 \mathrm{mg} \text { ) capsules } \\
\text { Three migraine attacks }\end{array}$ & $\begin{array}{l}\text { Sumatriptan was significantly more effective than Cafergot at } \\
\text { reducing the intensity of headache from severe or moderate to } \\
\text { mild or none; } 66 \% \text { ( } 145 / 220) \text { of those treated with sumatriptan } \\
\text { improved by } 2 \mathrm{~h} \text {, compared with } 48 \%(118 / 246) \text { of those treated } \\
\text { with Cafergot }(\mathrm{p}<0.001) \text {. The onset of headache resolution was } \\
\text { more rapid with sumatriptan, whereas recurrence of migraine } \\
\text { headache within } 48 \mathrm{~h} \text { was lower with Cafergot. } \\
\text { Sumatriptan was also significantly more effective at reducing } \\
\text { the incidence of nausea }(\mathrm{p}<0.001) \text {, vomiting }(\mathrm{p}<0.01) \text { and } \\
\text { photophobia/phonophobia }(\mathrm{p}<0.001) 2 \mathrm{~h} \text { after treatment, and } \\
\text { fewer patients on sumatriptan }(24 \%) \text { than on Cafergot }(44 \% \text {, } \mathrm{p}< \\
0.001) \text { required other medication after } 2 \mathrm{~h} \text {. The overall incidence } \\
\text { of patients reporting adverse events was } 45 \% \text { after sumatriptan } \\
\text { and } 39 \% \text { after Cafergot; the difference was not significant. }\end{array}$ \\
\hline Pascual et al. ${ }^{164}$ & $\begin{array}{l}\text { Adults - Rizatriptan } 10 \mathrm{mg} 38.5 \\
\text { years; Zolmitriptan } 2.5 \mathrm{mg} 39.4 \\
\text { years; Placebo } 38.2 \text { years. } \\
\mathrm{n}=766 \text { ( } 639 \text { female and } 127 \\
\text { male) }\end{array}$ & $\begin{array}{l}\text { Rizatriptan } 10 \mathrm{mg} \text { tablet } \\
\text { Zolmitriptan } 2.5 \mathrm{mg} \text { tablet } \\
\text { Single migraine attack }\end{array}$ & $\begin{array}{l}\text { The primary efficacy endpoint was pain free within } 2 \mathrm{~h} \text {. } \\
\text { Rizatriptan was superior to zolmitriptan, a HR }=1.26 \text {, rizatriptan } \\
\text { was } 26 \% \text { more likely to be eliminated in the next few minutes } \\
\text { than in a patient taking zolmitriptan. } \\
\text { Headache relief at } 2 \mathrm{~h} \text { - Rizatriptan } 70.5 \% \text { vs Zolmitriptan } 66.8 \% \\
\text { vs Placebo } 29.5 \% \text {. Headache recurrence at } 24 \mathrm{~h} \text { - Rizatriptan - } \\
28 \% \text {, Zolmitriptan } 29 \% \text { and placebo } 26 \% \text {. }\end{array}$ \\
\hline Pascual et al. ${ }^{165}$ & $\begin{array}{l}\text { Adults - placebo } 41.2 \text { years } \\
(19 \pm 63) ; \text { Almotriptan } 6.25 \\
\text { mg } 40.8 \text { years (19 } 196) ; \\
\text { Almotriptan } 12.5 \text { mg } 41.9 \\
\text { years ( } 18 \pm 65) \text {. } \\
\text { n=909 (788 female and } 121 \\
\text { male) }\end{array}$ & $\begin{array}{l}\text { Almotriptan } 6.25 \text { and } 12.5 \mathrm{mg} \\
\text { tablet } \\
\text { Placebo } \\
\text { Three consecutive migraine } \\
\text { attacks }\end{array}$ & $\begin{array}{l}\text { The total number of attacks relieved (severe or moderate pain } \\
\text { reduced to mild or no pain) at } 2 \mathrm{~h} \text { post-dose was significantly } \\
\text { higher }(\mathrm{P}<0.001) \text { after treatment with almotriptan } 6.25 \text { or } \\
12.5 \mathrm{mg} \text { compared with placebo }(60 \% \text { and } 70 \% \text { vs. } 38 \% \text {, } \\
\text { respectively). Moreover, a consistent response was achieved } \\
\text { across and within patients for almotriptan } 6.25 \text { or } 12.5 \mathrm{mg} \\
\text { compared with placebo (pain relief in at least } 2 \text { out of } 3 \text { attacks } \\
\text { within } 2 \mathrm{~h} \text { for } 64 \% \text { and } 75 \% \text { vs. } 36 \% \text {, respectively) and less than } \\
\text { one-third of the patients relapsed within } 24 \mathrm{~h} \text {. } \\
\text { Almotriptan was well tolerated with no significant differences } \\
\text { between the almotriptan and placebo treatment groups in the } \\
\text { percentage of patients reporting adverse events. }\end{array}$ \\
\hline
\end{tabular}




\begin{tabular}{|c|c|c|c|}
\hline Pascual et al. ${ }^{166}$ & $\begin{array}{l}\text { Adults }-33.7 \text { years (16-66) } \\
n=481 \text { (399 female and } 82 \\
\text { male) }\end{array}$ & $\begin{array}{l}\text { Rizatriptan } 10 \mathrm{mg} \text { (rapidly } \\
\text { disintegrating tablets) } \\
\text { Sumatriptan } 50 \mathrm{mg} \text { (tablets) } \\
\text { Single migraine attack }\end{array}$ & $\begin{array}{l}\text { The patients preferred rizatriptan } 10 \mathrm{mg} \text { rapidly disintegrating } \\
\text { tablet to sumatriptan } 50 \mathrm{mg} \text { tablet }(64.3 \text { vs. } 35.7 \%, \mathrm{p}<\text { or }= \\
0.001) \text {. Faster relief of headache pain was the most important } \\
\text { reason for the preference, cited by } 46.9 \% \text { of patients preferring } \\
\text { rizatriptan and } 43.4 \% \text { of patients who preferred sumatriptan. } \\
\text { Headache relief at } 2 \mathrm{~h} \text { was } 75.9 \% \text { with rizatriptan and } 66.6 \% \text { with } \\
\text { sumatriptan ( }<\text { or }=0.001) \text {, with rizatriptan being superior to } \\
\text { sumatriptan within } 30 \text { min of dosing. Fifty-five percent of patients } \\
\text { were pain free } 2 \mathrm{~h} \text { after rizatriptan, compared with } 42.1 \% \text { treated } \\
\text { with sumatriptan ( } \mathrm{p}<\text { or }=0.001) \text {, rizatriptan being superior } \\
\text { within } 1 \mathrm{~h} \text { of treatment. Forty-one percent of patients taking } \\
\text { rizatriptan were pain free at } 2 \mathrm{~h} \text { and had no recurrence or need } \\
\text { for additional medication, compared to } 32.3 \% \text { of patients on } \\
\text { sumatriptan. Rizatriptan was also superior to sumatriptan in terms } \\
\text { of the proportions of patients with no nausea, phonophobia or } \\
\text { photophobia, and patients with normal function } 2 \mathrm{~h} \text { after treatment } \\
\text { intake ( } \mathrm{p}<0.05) \text {. } \\
\text { More patients were satisfied } 2 \mathrm{~h} \text { after treatment with rizatriptan } \\
\text { (73.3\%) than } 2 \mathrm{~h} \text { after treatment with sumatriptan }(59.0 \%) \text { (p }< \\
\text { or }=0.001) \text {. Both active treatments were well tolerated. } \\
\text { The most common side effects with rizatriptan and sumatriptan } \\
\text { were nausea (6.6 and } 6.9 \% \text { of patients, respectively), dizziness } \\
\text { (6. } 1 \text { and } 5.8 \% \text { ) and somnolence ( } 7.4 \text { and } 6.7 \%) \text {. }\end{array}$ \\
\hline Pini et al. ${ }^{167}$ & $\begin{array}{l}\text { Adults - mean age } 37.0 \text { years, } \\
\text { range } 18-65 \text { years) } \\
n=238 \text { ( } 52 \text { males and } 186 \\
\text { females) }\end{array}$ & $\begin{array}{l}\text { Sumatriptan } 100 \mathrm{mg} \text { oral } \\
\text { Placebo } \\
\text { Single migraine attack }\end{array}$ & $\begin{array}{l}\text { Reduction in headache intensity - sumatriptan } 65 \% \text { versus } \\
\text { placebo } 40 \% \text {. Reductions in accompanying symptoms of } \\
\text { migraine - nausea/vomiting ( } 33 \text { versus } 53 \% \text { ) and photophobia/ } \\
\text { phonophobia ( } 37 \text { versus } 62 \% \text { ), respectively. } \\
\text { Sumatriptan was very effective in reducing headache severity in } \\
\text { patients with a history of prolonged migraine attacks (sumatriptan } \\
67 \% \text { versus } 26 \% \text { placebo). }\end{array}$ \\
\hline Pini et al. ${ }^{168}$ & $\begin{array}{l}\text { Adults - male } 33.6 \pm 10.5 \text { and } \\
\text { female } 35.6 \pm 9.6 \text { years. } \\
n=92 \text { (Male } 31 \text { and Female 61) }\end{array}$ & $\begin{array}{l}\text { Paracetamol } 1000 \mathrm{mg} \text { + caffeine } \\
130 \text { mg sachet } \\
\text { Sumatriptan } 50 \mathrm{mg} \text { soft gel } \\
\text { capsule } \\
\text { Two migraine attacks }\end{array}$ & $\begin{array}{l}\text { There was no difference between the two treatments regarding } \\
\text { total pain relief pain during the } 4 \text {-hour observation period. }\end{array}$ \\
\hline Rahimdel et al. ${ }^{169}$ & $\begin{array}{l}\text { Adults - sodium valproate } \\
31.3 \pm 3.5 \text { years, Sumatriptan } 6 \\
\text { mg } 30.1 \pm 3.1 \text { years. } \\
\mathrm{n}=90 \text { ( } 67 \text { female and } 23 \text { male) }\end{array}$ & $\begin{array}{l}\text { Sodium valproate } 400 \mathrm{mg} \text { IV } \\
\text { Sumatriptan } 6 \mathrm{mg} \mathrm{SC} \\
\text { Single migraine attack }\end{array}$ & $\begin{array}{l}\text { In both groups, pain decrement at the mentioned time points was } \\
\text { significant }(P<0.001) \text { but had no significant difference }(P>0.05) \text {, } \\
\text { indicating the similar effect of both drugs on pain improvement. } \\
\text { In the Sodium valproate group, photophobia, phonophobia, } \\
\text { nausea, and vomiting were improved significantly, while in } \\
\text { the Sumatriptan group, only photophobia and vomiting were } \\
\text { decreased significantly. Nausea, vomiting, facial paresthesia, and } \\
\text { hypotension were more significantly frequent in the Sumatriptan } \\
\text { group than in the Sodium valproate group }(P<0.05) \text {. }\end{array}$ \\
\hline Rao et al. ${ }^{170}$ & $\begin{array}{l}\text { Adults }-36.3 \pm 9.8 \text { years } \\
\mathrm{n}=54 \text { (Female } 98.1 \% \text { and } \\
\text { Male } 1.9 \% \text { ) }\end{array}$ & $\begin{array}{l}\text { Ketorolac nasal spray } 31.5 \mathrm{mg} \\
\text { Sumatriptan nasal spray } 20 \mathrm{mg} \\
\text { Placebo } \\
\text { At least one attack }\end{array}$ & $\begin{array}{l}\text { Both ketorolac }(72.5 \%, \mathrm{P}<.001 \text { ) and sumatriptan }(69.4 \%, \mathrm{P}= \\
.001 \text { ) were more effective than placebo }(38.3 \%) \text { for } 2 \text {-hour pain } \\
\text { relief and } 2 \text {-hour pain freedom (ketorolac: } 43.1 \%, \mathrm{P}=.004 \text {; } \\
\text { sumatriptan: } 36.7 \%, \mathrm{P}=.046 \text {; placebo: } 18.4 \%) \text {. } \\
\text { Ketorolac but not sumatriptan was more effective than placebo } \\
\text { in } 2 \text {-hour absence of nausea. Both ketorolac and sumatriptan } \\
\text { were more effective than placebo for } 24 \text {-hour sustained pain } \\
\text { relief (ketorolac: } 49 \%, \mathrm{P}<.001 \text {; sumatriptan: } 31 \%, \mathrm{P}=.01 \text {, } \\
\text { placebo: } 20 \%) \text {. Only ketorolac was superior to placebo for } 24 \text { - } \\
\text { hour (ketorolac: } 35.3 \%, \mathrm{P}=.003 \text {; sumatriptan: } 22.4 \%, \mathrm{P}=.18 \text {, } \\
\text { placebo: } 12.2 \% \text { ) sustained pain freedom. } \\
\text { Nasal burning and dysgeusia were the most common adverse } \\
\text { effects for active treatments. }\end{array}$ \\
\hline Rapoport et al. ${ }^{171}$ & $\begin{array}{l}\text { Adults - } 18 \text { to } 65 \text { years } \\
\text { (sumatriptan } 6 \text { mg+placebo: } \\
42.3 \text { years; sumatriptan- } \\
6 \text { mg+100mg: } 42.5 \text { years) } \\
n=667 \text { ( } 118 \text { male and } 549 \\
\text { female) }\end{array}$ & $\begin{array}{l}\text { Sumatriptan } 6 \mathrm{mg} \mathrm{SC}+ \\
\text { Sumatriptan } 100 \mathrm{mg} \text { (oral - } 4 \mathrm{hs} \\
\text { later) } \\
\text { Sumatriptan } 6 \mathrm{mg} \mathrm{SC}+\text { Placebo } \\
\text { (oral - 4hs later) } \\
\text { Three migraine attacks }\end{array}$ & $\begin{array}{l}\text { The primary efficacy endpoint was the number of successfully } \\
\text { treated patients without headache recurrence (HR) within } 24 \\
\text { hours atter the initial SC injection for the first study attack. } \\
237 / 317 \text { patients who received oral sumatriptan at } 4 \text { hours } \\
(75 \%) \text { and } 249 / 312 \text { patients who received placebo at } 4 \text { hours } \\
(80 \%) \text { reported no or mild headache pain at } 2 \text { hours after the } \\
\text { initial open dose of } 6 \text { mg SC sumatriptan. By } 4 \text { hours, relief was } \\
\text { reported by } 78 \% \text { of the patients who received oral sumatriptan } \\
\text { and } 82 \% \text { of the patients who received placebo. } \\
\text { Of } 442 \text { assessable patients, } 82 / 212 \text { in the sumatriptan-treated } \\
\text { group (39\%) and } 89 / 230 \text { in the placebo-treated group ( } 39 \% \text { ) } \\
\text { reported HR in attack } 1 \text {. Median times to recurrence were } \\
15.6 \text { hours after sumatriptan and } 10.3 \text { hours after placebo } \\
\text { (p }=0.006 \text { ). After placebo, } 58 \% \text { of the recurrences occurred } \\
\text { within } 12 \text { hours, compared with only } 32 \% \text { within } 12 \text { hours after } \\
\text { sumatriptan. } \\
\text { Similar results were observed for attacks } 2 \text { and } 3 \text {. }\end{array}$ \\
\hline
\end{tabular}




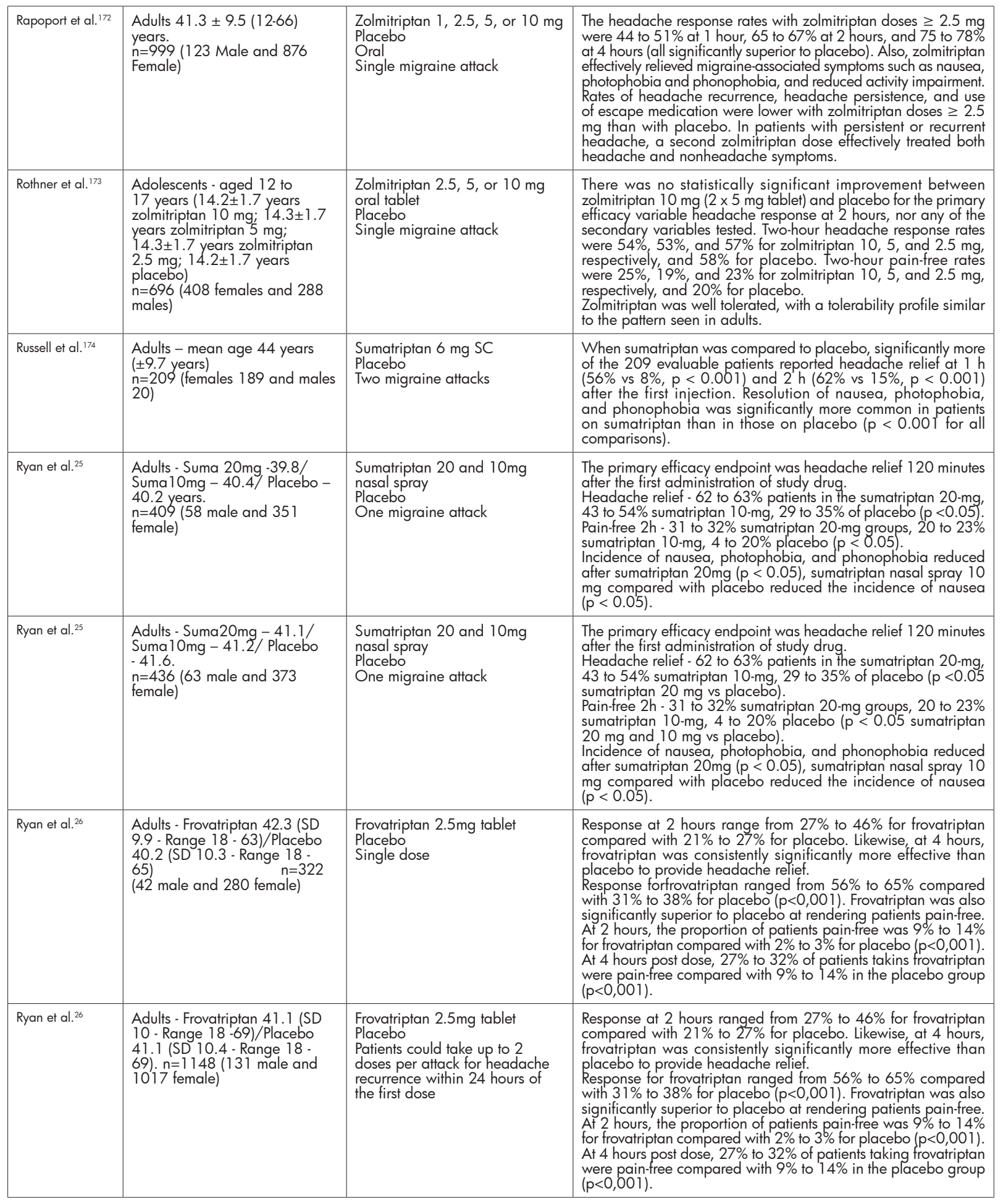




\begin{tabular}{|c|c|c|c|}
\hline Ryan et al. ${ }^{26}$ & $\begin{array}{l}\text { Adults - Frovatriptan } 41.1 \\
\text { (SD 10.4-Range } 18-69 \text { )/ } \\
\text { Placebo } 40.3 \text { (SD } 10.8 \text { - Range } \\
19-69 \text { ). } \\
n=724(106 \text { male and } 618 \\
\text { female) }\end{array}$ & $\begin{array}{l}\text { Frovatriptan } 2.5 \mathrm{mg} \text { tablet } \\
\text { Placebo } \\
\text { Patients could take up to two } \\
\text { doses per attack for headache } \\
\text { recurrence within } 24 \text { hours of } \\
\text { the first dose }\end{array}$ & $\begin{array}{l}\text { Response at } 2 \text { hours ranged from } 27 \% \text { to } 46 \% \text { for frovatriptan } \\
\text { compared with } 21 \% \text { to } 27 \% \text { for placebo. Likewise, at } 4 \text { hours, } \\
\text { frovatriptan was consistently significantly more effective than } \\
\text { placebo ar providing headache relief. Response for frovatriptan } \\
\text { ranged from } 56 \% \text { to } 65 \% \text { compared with } 31 \% \text { to } 38 \% \text { for } \\
\text { placebo }(p<0.001) \text {. Frovatriptan was also significantly superior to } \\
\text { placebo at rendering patients pain-free. At } 2 \text { hours, the proportion } \\
\text { of patients pain-free was } 9 \% \text { to } 14 \% \text { for frovatriptan compared } \\
\text { with } 2 \% \text { to } 3 \% \text { for placebo }(p<0.001) \text {. At } 4 \text { hours post dose, } 27 \% \\
\text { to } 32 \% \text { of patients taking frovatriptan were pain-free compared } \\
\text { with } 9 \% \text { to } 14 \% \text { in the placebo group }(p<0.001) \text {. }\end{array}$ \\
\hline Sandrini et al. ${ }^{174}$ & $\begin{array}{l}\text { Adults - } 18 \text { to } 65 \text { years } \\
\text { [placebo: } 37.5 \pm 10.9 ; \\
\text { suma50mg: } 37.4 \pm 10.2 ; \\
\text { suma 100mg: } 38.2 \pm 10.2 \\
\text { ele } 40 \mathrm{mg}: 38.0 \pm 10.1 ; \\
\text { ele80mg:39.9 } \\
\text { n=774 (681 female and } 93 \\
\text { male) }\end{array}$ & $\begin{array}{l}\text { Eletriptan } 40 \mathrm{mg} \\
\text { Eletriptan } 80 \mathrm{mg} \text { tablets } \\
\text { Sumatriptan } 50 \mathrm{mg} \\
\text { Sumatriptan } 100 \mathrm{mg} \\
\text { Placebo } \\
\text { gelatin capsules } \\
\text { Multiple migraine attack }\end{array}$ & $\begin{array}{l}\text { Headache response rates were } 12 \% \text { at } 1 \text { hour and } 31 \% \text { at } \\
2 \text { hours for placebo; } 24 \% \text { at } 1 \text { hour and } 50 \% \text { at } 2 \text { hours for } \\
\text { sumatriptan } 50 \mathrm{mg} ; 27 \% \text { at } 1 \text { hour and } 53 \% \text { at } 2 \text { hours for } \\
\text { sumatriptan } 100 \mathrm{mg} ; 30 \% \text { at } 1 \text { hour and } 64 \% \text { at } 2 \text { hours for } \\
\text { eletriptan } 40 \mathrm{mg} \text {; and } 37 \% \text { at } 1 \text { hour and } 67 \% \text { at } 2 \text { hours for } \\
\text { eletriptan } 80 \mathrm{mg} \text {. } \\
\text { More patients receiving eletriptan } 80 \mathrm{mg} \text { achieved a } 1 \text {-hour } \\
\text { headache response than did patients receiving sumatriptan } 50 \\
\text { mg (p } 0.05 \text { ). All doses of eletriptan were superior to sumatriptan } \\
\text { at } 2 \text { hours for headache response and complete pain relief ( } p< \\
0.05 \text { ). Significantly more patients on eletriptan } 80 \mathrm{mg} \text { achieved } \\
\text { headache response in all attacks than did patients receiving } \\
\text { sumatriptan. } \\
\text { Eletriptan } 40 \text { mg was superior to both sumatriptan doses in } \\
\text { functional improvement (p< } 0.005 \text { ). The } 40 \text { - and } 80 \text {-mg doses } \\
\text { of eletriptan were significantly more effective than placebo or } \\
\text { sumatriptan in reducing the associated migraine symptoms of } \\
\text { nausea, photophobia, and phonophobia after } 2 \text { hours. } \\
\text { The } 40 \text { - and } 80 \text {-mg doses of eletriptan were significantly superior } \\
\text { to oral sumatriptan or placebo in achieving and sustaining both } \\
\text { headache response and pain-free response at } 24 \text { hours. The } \\
\text { superior efficacy of both eletriptan doses was associated with } \\
\text { higher rates of patient acceptability than sumatriptan } 50 \text { mg } \\
\text { (p < } 0.05 \text { ). } \\
\text { Eletriptan and sumatriptan were well tolerated. }\end{array}$ \\
\hline Sandrini et al. ${ }^{175}$ & $\begin{array}{l}\text { Adults - mean age } 35 \pm 9.8 \\
\text { years } \\
n=281 \text { ( } 78 \% \text { female and } 22 \% \\
\text { male) }\end{array}$ & $\begin{array}{l}\text { Sumatriptan } 50 \mathrm{mg} \text { tablets } \\
\text { Indoprocaf-coated tablets } \\
\text { Indoprocaf-effervescent tablets } \\
\text { Two consecutive migraine } \\
\text { attacks } \\
\text { Indoprocaf - indomethacin, } \\
\text { prochlorperazine and caffeine }\end{array}$ & $\begin{array}{l}\text { Pain-free rates at } 2 \mathrm{~h} \text { (all attacks) - } 34 \% \text { Indoprocaf and } 37 \% \\
\text { sumatriptan ( } \mathrm{p}=\mathrm{NS}) \text {. Headache relief at } 2 \mathrm{~h} \text { (all attacks) postdose } \\
-62 \% \text { Indoprocaf and } 56 \% \text { with sumatriptan ( } \mathrm{p}=\mathrm{NS} \text { ). } \\
\text { Pain free } 2 \mathrm{~h} \text { post first attack (indoprocaf coated-tablets vs } \\
\text { effervescent tablets). Indoprocaf-effervescent tablets } 41 \% \text { vs. } \\
\text { Coated-tablets } 22 \%(\mathrm{P}<0.05) \text {. Headache relief rate at } 2 \mathrm{~h} \\
\text { postdose in the first attack - Effervescent tablets } 66 \% \text { vs. Coated- } \\
\text { tablets } 49 \% \text { ( } \mathrm{p}<0.05 \text { ). Pain-free rate total attacks - Effervescent } \\
\text { tablet } 84 \% \text { vs. Coated-tablets } 73 \% \text {. The total pain-free rate of } \\
\text { Indoprocaf-coated tablets was lower than that of effervescent } \\
\text { tablets, but higher than sumatriptan. }\end{array}$ \\
\hline Sang et al. ${ }^{176}$ & $\begin{array}{l}\text { Adults - mean age } 40 \pm 9 \\
\text { years. } \\
n=44 \text { ( } 20 \text { male and } 24 \text { female) }\end{array}$ & $\begin{array}{l}\text { Ly } 293558 \text { (nonselective AMPA/ } \\
\text { KA (GluR5) receptor antagonist } \\
\text { with } 1.2 \mathrm{mg} / \mathrm{kg} \mathrm{IV} \\
\text { Sumatriptan } 6 \mathrm{mg} \mathrm{SC} \\
\text { Placebo } \\
\text { Simgle migraine attack }\end{array}$ & $\begin{array}{l}\text { The primary efficacy variable was the headache response rate, } \\
\text { i.e. headache score improvement from moderate/severe at } \\
\text { baseline to mild/none at } 2 \mathrm{~h} \text {. Response rates were } 69 \% \text { for } \\
\text { LY293558 ( } P=0.017 \text { vs. placebo), } 86 \% \text { for sumatriptan }(P< \\
0.01 \text { vs. placebo) and } 25 \% \text { for placebo. } \\
\text { LY293558 and sumatriptan were superior to placebo ( } P<0.01 \\
\text { for all comparisons) on all other measures of improvement in pain } \\
\text { and migraine associated symptoms. } \\
\text { Fifteen percent of patients who took LY } 293558 \text { reported adverse } \\
\text { events, } 53 \% \text { patients who took sumatriptan and } 31 \% \text { of those } \\
\text { who received placebo reported adverse events. }\end{array}$ \\
\hline $\begin{array}{l}\text { Santanello et } \\
\text { al. }{ }^{177}\end{array}$ & $\begin{array}{l}\text { Adults - Rizatriptan } 10 \mathrm{mg}- \\
36.8 \text { (SD 9); Rizatriptan } 5 \mathrm{mg} \\
-37.6 \text { (SD 8.2); Rizatriptan } \\
2.5 \mathrm{mg}-38.7 \text { (SD } 9.1) \text {; } \\
\text { Placebo }-39.7 \text { (SD } 9.7 \text { ) years } \\
\mathrm{n}=247 \text { (222 female and } 25 \\
\text { male) }\end{array}$ & $\begin{array}{l}\text { Rizatriptan } 2.5,5 \text { and } 10 \mathrm{mg} \\
\text { Placebo } \\
\text { Oral } \\
\text { One migraine attack }\end{array}$ & $\begin{array}{l}\text { Statiscally significant mean improvements were observed for those } \\
\text { treated with rizatriptan } 10 \mathrm{mg} \text { compared with those treated with } \\
\text { placebo on three of five domains: social functioning }(p=0,007) \text {, } \\
\text { migraine symptoms ( } p=0.005) \text {, and feeling/concerns }(p=0.015) \text {. } \\
\text { Patients who took the } 5-\mathrm{mg} \text { and } 10 \mathrm{mg} \text { rizatriptan doses were } \\
\text { significantly less disabled as } 2 \mathrm{~h} \text { than those who took placebo } \\
(\mathrm{p}=0.003) \text {; however, the patients who took } 2,5 \mathrm{mg} \text { rizatriptan } \\
\text { remained about as functionally disabled as patients on placebo. }\end{array}$ \\
\hline Savi et al. ${ }^{178}$ & $\begin{array}{l}\text { Adults }-37 \pm 9 \text { years } \\
n=125 \text { (99 female } 26 \text { male) }\end{array}$ & $\begin{array}{l}\text { Frovatriptan } 2.5 \mathrm{mg} \\
\text { Rizatriptan } 10 \mathrm{mg} \\
\text { Capsules } \\
\text { Treat } 1-3 \text { attacks }\end{array}$ & $\begin{array}{l}\text { Patient's preference for one drug or the other did not differ } \\
\text { between the study treatments. Frovatriptan was chosen mainly } \\
\text { because of the rapid speed of action ( } 71 \% \text { of patients), good } \\
\text { tolerability (42\% of patients), and reduction in pain severity } \\
\text { ( } 33 \% \text { ). } \\
\text { A relevant result of study was that recurrence rate within } 48 \mathrm{~h} \text { were } \\
\text { significantly lower under frovatriptan than under rizatriptan. These } \\
\text { differences may be explained by the different pharmacokinetics of } \\
\text { the two drugs. Frovatriptan has a time to maximum concentration } \\
\text { typically of } 2 \text { to } 3 \mathrm{~h} \text {, but the longest half-life among triptans, } \\
\text { greater } 5-\mathrm{HT} 1 \mathrm{~B} \text { binding receptor potency, and multiple pathways } \\
\text { metabolism. The headache recurrence was significantly less } \\
\text { frequent with frovatriptan than under rizatriptan. }\end{array}$ \\
\hline
\end{tabular}




\begin{tabular}{|c|c|c|c|}
\hline $\begin{array}{l}\text { Savi, Mogavero, } \\
\text { Egan. }{ }^{179}\end{array}$ & $\begin{array}{l}\text { Adults }-39.4 \pm 7.8 \text { years } \\
n=18(55.5 \% \text { female and } \\
44.4 \% \text { male })\end{array}$ & $\begin{array}{l}\text { Frovatriptan } 2.5 \mathrm{mg} \\
\text { Rizatriptan } 10 \mathrm{mg} \\
\text { Two-treatmen migraine attack }\end{array}$ & $\begin{array}{l}\text { The primary endpoint of interest was the correlation between } \\
\text { plasma concentration of each triptan (and more specifically the } \\
\text { concentration: maximum concentration (Cmax) ratio and the } \\
\text { pain-free (PF) and pain-relief (PR) rates at each time point. PF } \\
4 \mathrm{~h} \text { - Frovatriptan } 38.4 \% \text { vs Rizatriptan } 5.6 \%(p=0.045) \text {. PR at } \\
4 \mathrm{~h} \text { - Frovatriptan } 61.1 \% \text { vs Rizatriptan } 72.2 \%(\mathrm{p}=\mathrm{NS}) \text {. } \\
\text { There was a positive correlation between frovatriptan } \\
\text { concentration: Cmax ratio (\%) and the proportion of patients } \\
\text { that were either pain free or experienced pain relief over the } \\
\text { entire study period. No such correlation was seen for rizatriptan. }\end{array}$ \\
\hline Schulman ${ }^{180}$ & $\begin{array}{l}\text { Adults - aged } 18-66 \text { years } \\
\text { - mean (SD) } 40.7 \text { (11.2 } \\
\text { (Transdermal Sumatriptan and } \\
41.0 \text { (11.0) Placebo. } \\
\mathrm{n}=454 \text { (male } 68 \text { and female } \\
386 \text { ) }\end{array}$ & $\begin{array}{l}\text { Sumatriptan transdermal patch } \\
\text { Placebo } \\
\text { Single migraine attack }\end{array}$ & $\begin{array}{l}\text { In the overall study population, transdermal sumatriptan was } \\
\text { significantly superior to placebo at } 1 \text { hour post-activation for pain } \\
\text { relief ( } 29 \% \text { vs } 19 \% \text {, respectively; } P<.0135) \text { and freedom from } \\
\text { nausea }(71 \% \text { vs } 58 \% \text {, respectively; } P<.05 \text { ) and at } 2 \text { hours post- } \\
\text { activation for freedom from pain }(18 \% \text { vs } 9 \% \text {, respectively; } P< \\
.009) \text {, pain relief }(53 \% \text { vs } 29 \% \text {, respectively; } P<.0001) \text {, freedom } \\
\text { from nausea ( } 84 \% \text { vs } 63 \% \text { respectively; } P<.001) \text {, freedom from } \\
\text { photophobia ( } 51 \% \text { vs } 36 \% \text {, respectively; } P<.0028) \text {, freedom } \\
\text { from phonophobia ( } 55 \% \text { vs } 39 \% \text {, respectively; } P<.0002) \text {; and } \\
\text { freedom from migraine ( } 16 \% \text { vs } 8 \% \text {, respectively; } P<.0135) \text {. } \\
\text { In the post-hoc analysis, transdermal sumatriptan was markedly } \\
\text { superior to placebo for pain relief and freedom from pain, } \\
\text { nausea, photo and phonophobia at } 1 \text { and } 2 \text { hours post-activation. }\end{array}$ \\
\hline Scott et al. ${ }^{181}$ & $\begin{array}{l}\text { Adults - Group SS(S): } 41.0+ \\
11.1 \text { years; Group SS(P): } 40.4 \\
\pm 10.7 \text { years; Group SP(S): } \\
40.6 \\
\pm 10.5 \text { years; Group: SP(P): } \\
42.1 \\
\pm 10.6 \text { years. } \\
n=1440 \text { ( } 214 \text { male and } 1226 \\
\text { female) }\end{array}$ & $\begin{array}{l}\text { Sumatriptan } 100 \mathrm{mg} \text { tablet oral } \\
\text { Placebo } \\
\text { Three migraine attack }\end{array}$ & $\begin{array}{l}\text { Headache was relieved by the first sumatriptan dose in about } \\
70 \% \text { of patients, but the second dose did not produce significantly } \\
\text { more relief than placebo, either in non-responders or in the group } \\
\text { as a whole, nor did it reduce other symptoms (photophobia, } \\
\text { nausea, vomiting, etc.) at } 8 \mathrm{~h} \text {, or influence the incidence of } \\
\text { headache recurrence. } \\
\text { The drug was well-tolerated, and a further single dose was } \\
\text { effective in treating recurrence after initial relief. Of those } \\
\text { patients who treated at least one attack and expressed a view } \\
\text { of the treatment, } 80 \% \text { ( } n=1056 \text { ) said that they would take the } \\
\text { medication again. }\end{array}$ \\
\hline $\begin{array}{l}\text { Seeburger et } \\
\text { al. }{ }^{182}\end{array}$ & $\begin{array}{l}\text { Adults - } 43.8 \text { years }(20-68) \\
\text { [Riza/riza/placebo } 43.3 \text { years } \\
(20-68) ; \text { Riza/placebo/riza } \\
44.8 \text { years }(28-61) ; \text { Placebo/ } \\
\text { riza/riza } 43.5 \text { years (23-64);] } \\
\text { n=102 (female } 88 \text { and } 14 \\
\text { male) }\end{array}$ & $\begin{array}{l}\text { Rizatriptan } 10 \text { mg ODT tablet/ } \\
\text { oral lyophilisate } \\
\text { Placebo } \\
\text { Three migraine attack crossover }\end{array}$ & $\begin{array}{l}\text { Pain relief at two hours was significantly greater with rizatriptan } \\
\text { compared with placebo ( } 51 \% \text { vs. } 20 \% \text {, } \mathrm{p}<.001) \text {. Response rates } \\
\text { also favored rizatriptan on two-hour pain freedom ( } 22 \% \text { vs. } 12 \% \text {, } \\
\mathrm{p}=.013) \text { as well as } 24 \text {-hour sustained pain relief }(38 \% \text { vs. } 14 \% \text {, } \\
\mathrm{p}<.001) \text { and sustained pain freedom }(20 \% \text { vs. } 11 \%, \mathrm{p}=.036) \text {. } \\
\text { Treatment was generally well-tolerated. }\end{array}$ \\
\hline $\begin{array}{l}\text { Sheftell, Ryan, } \\
\text { Pitman }{ }^{184}\end{array}$ & $\begin{array}{l}\text { Eletrip } 20 \mathrm{mg}-41(19-73) ; \\
40 \mathrm{mg}-42(18-78) ; 80 \mathrm{mg}-41 \\
\text { (19-75); Placebo }-42(18-69) \\
\text { years } \\
\text { n=1190 (1037 female and } \\
153)\end{array}$ & $\begin{array}{l}\text { Eletriptan } 20,40 \text { and } 80 \mathrm{mg} \\
\text { oral } \\
\text { Placebo } \\
\text { Three migraine attacks }\end{array}$ & $\begin{array}{l}\text { A significantly higher proportion of patients treated with eletriptan } \\
\text { reported a headache response at } 2 \text { hours compared to the } \\
\text { placebo group ( } 47 \%, 62 \% \text {, and } 59 \% \text { for the } 20-\mathrm{mg}, 40-\mathrm{mg} \text {, and } \\
80-\mathrm{mg} \text { doses, respectively, compared with } 22 \% \text { in the placebo } \\
\text { group, P <0.0001 for all eletriptan doses). }\end{array}$ \\
\hline Sheftell et al. ${ }^{27}$ & $\begin{array}{l}\text { Adults - Sumatriptan 100mg } \\
-41.5 \text { (SD 11.2); Sumatriptan } \\
50 \mathrm{mg}-41.6 \text { (SD 10.8); } \\
\text { Placebo - } 41.2 \text { (SD 10.8) } \\
\text { years. } \\
\text { n=1366 (1170 female and } \\
196 \text { male) }\end{array}$ & $\begin{array}{l}\text { Sumatriptan } 100 \mathrm{mg} \text { tablets } \\
\text { rapid release } \\
\text { Sumatriptan } 50 \mathrm{mg} \text { tablets rapid } \\
\text { release } \\
\text { Placebo } \\
\text { Single migraine attack }\end{array}$ & $\begin{array}{l}\text { Using pooled data, the cumulative percentages patients with pain } \\
\text { relief by } 2 \text { hours after dosing were } 67 \% \text { for sumatriptan tablets } \\
50 \text { mg and } 72 \% \text { for sumatriptan tablets } 100 \text { mg, compared with } \\
42 \% \text { for placebo ( } P<0.001 \text {, both sumatriptan doses vs placebo). } \\
\text { The cumulative percentages of patients with a pain-free response } \\
\text { by } 2 \text { hours after dosing were } 40 \% \text { for sumatriptan tablets } 50 \\
\text { mg and } 47 \% \text { for sumatriptan tablets } 100 \mathrm{mg} \text {, compared with } \\
15 \% \text { for placebo. }\end{array}$ \\
\hline Sheftell et al. ${ }^{27}$ & $\begin{array}{l}\text { Adults - Sumatriptan 100mg } \\
-40.1 \text { (SD 10.8); Sumatriptan } \\
50 \mathrm{mg} 39.9 \text { (SD 10.8); Placebo } \\
-39.2 \text { (SD 10.5) } \\
\mathrm{n}=1330 \text { ( } 1126 \text { female and } \\
204 \text { male) }\end{array}$ & $\begin{array}{l}\text { Sumatriptan } 100 \mathrm{mg} \text { tablets } \\
\text { rapid release } \\
\text { Sumatriptan } 50 \mathrm{mg} \text { tablets rapid } \\
\text { release } \\
\text { Placebo } \\
\text { Single migraine attack }\end{array}$ & $\begin{array}{l}\text { Using pooled data, the cumulative percentages patients with pain } \\
\text { relief by } 2 \text { hours after dosing were } 67 \% \text { for sumatriptan tablets } \\
50 \text { mg and } 72 \% \text { for sumatriptan tablets } 100 \text { mg, compared with } \\
42 \% \text { for placebo ( } P<0.001 \text {, both sumatriptan doses vs placebo). } \\
\text { The cumulative percentages of patients with a pain-free response } \\
\text { by } 2 \text { hours after dosing were } 40 \% \text { for sumatriptan tablets } 50 \\
\text { mg and } 47 \% \text { for sumatriptan tablets } 100 \text { mg, compared with } \\
15 \% \text { for placebo. }\end{array}$ \\
\hline
\end{tabular}




\begin{tabular}{|c|c|c|c|}
\hline $\begin{array}{l}\text { Silberstein et } \\
\text { al. }{ }^{185}\end{array}$ & $\begin{array}{l}\text { Adults - mean age } 40 \text { years } \\
n=1419 \text { (female only) }\end{array}$ & $\begin{array}{l}\text { Rizatriptan } 5 \mathrm{mg} \text { and } 10 \mathrm{mg} \text { oral } \\
\text { Placebo }\end{array}$ & $\begin{array}{l}\text { In the subgroup of } 335 \text { women with menstrually associated } \\
\text { migraine, rizatriptan was effective compared with placebo. At } \\
2 \text { hours after dosing, } 68 \% \text { of } 139 \text { women taking rizatriptan } \\
10 \text { mg and } 70 \% \text { of } 115 \text { women taking rizatriptan } 5 \text { mg with a } \\
\text { menstrually associated migraine had pain relief compared with } \\
44 \% \text { of } 81 \text { patients taking placebo ( }<<.05) \text {. In all women, } \\
\text { rizatriptan was as effective in treating menstrual as well as } \\
\text { nonmenstrual migraine: } 68 \% \text { of } 139 \text { patients taking rizatriptan } \\
10 \text { mg with a menstrually associated migraine had pain relief at } \\
2 \text { hours after dosing compared with } 69 \% \text { of } 393 \text { patients with } \\
\text { nonmenstrually associated attacks (test of menstrual association } 5 \\
\text { nonsignificant; the analysis had } 80 \% \text { power to detect a difference } \\
\text { of six percentage points between groups). Similar results were } \\
\text { found for rizatriptan } 5 \text { mg (menstrual } 70 \% \text {, nonmenstrual } 66 \% \text {; } \\
\text { not statistically significant). }\end{array}$ \\
\hline $\begin{array}{l}\text { Silberstein et } \\
\text { al. }{ }^{186}\end{array}$ & $\begin{array}{l}\text { Adults }-37.6 \text { years }(18-56) \\
n=546 \text { (female only) }\end{array}$ & $\begin{array}{l}\text { Frovatriptan } 2.5 \mathrm{mg} \text { tablet QD } \\
\text { Frovatriptan } 2.5 \mathrm{mg} \text { tablet BID } \\
\text { Placebo } \\
\text { Three-way crossover design }\end{array}$ & $\begin{array}{l}\text { Use of frovatriptan reduced the occurrence of menstrually } \\
\text { associated migraine. The incidence of menstrually associated } \\
\text { migraine during } 6 \text {-day was } 67 \% \text { for placebo, } 52 \% \text { for frovatriptan } \\
2.5 \mathrm{mg} Q D \text {, and } 41 \% \text { for frovatriptan } 2.5 \mathrm{mg} B I D \text {. } \\
\text { Both frovatriptan regimens were superior to placebo }(p<0.0001) \text {, } \\
\text { and the BID regimen was superior to the } Q D \text { regimen }(p<0.001) \text {, } \\
\text { Both frovatriptan regimens also reduced menstrually associated } \\
\text { migraine severity ( } p<0.0001) \text {, duration }(p<0.0001) \text {, and the } \\
\text { use of rescue medication }(p<0.01 \mathrm{QD} ; \mathrm{p}<0.0001 \text { BID) in a } \\
\text { dose-dependent manner. } \\
\text { The incidence and type of adverse events for both regimens were } \\
\text { similar to placebo and consistent with those reported for short } \\
\text { term migraine management. }\end{array}$ \\
\hline Silberstein et al. ${ }^{32}$ & $\begin{array}{l}\text { Adults }-18-65 \text { years. } \\
n=275\end{array}$ & $\begin{array}{l}\text { Sumatriptan } 22 \mathrm{mg} \text { nasal } \\
\text { powder } \\
\text { Sumatriptam } 100 \mathrm{mg} \text { oral } \\
\text { Two treatment sequences }\end{array}$ & 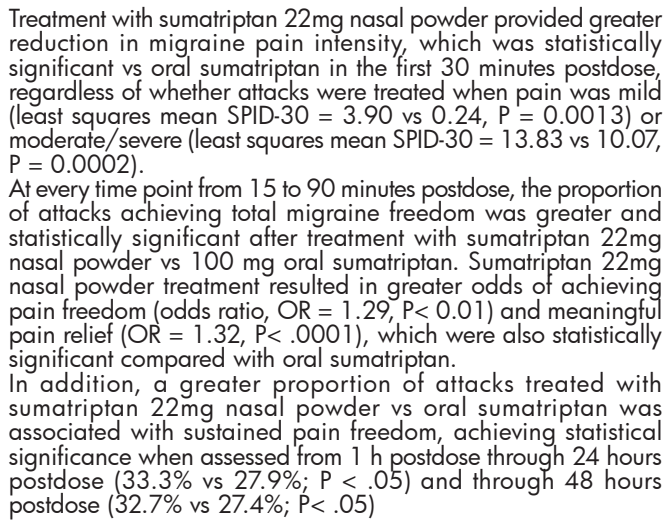 \\
\hline Smith et al. ${ }^{187}$ & $\begin{array}{l}\text { Adults - Sumatriptan } 50 \mathrm{mg} \mathrm{E} \\
+ \text { Naproxen sodium } 500 \mathrm{mg} \\
-42.5 \pm 11.0 ; \text { Sumatriptan } 50 \\
\text { mg } \mathrm{E}-41.2 \pm 11.3 ; \text { Naproxen } \\
\text { sodium } 500 \mathrm{mg}-42.1 \pm 10.7 \text {; } \\
\text { Placebo }-41.2 \pm 10.2 \text { years. } \\
\mathrm{n}=972 \text { ( } 880 \text { female and } 92 \\
\text { male) }\end{array}$ & $\begin{array}{l}\text { Sumatriptan } 50 \mathrm{mg} \text { tablet } \\
\text { Naproxen } 500 \mathrm{mg} \text { tablet } \\
\text { Sumatriptan } 50 \mathrm{mg} \text { + Naproxen } \\
\text { sodium } 500 \mathrm{mg} \\
\text { Placebo } \\
\text { Single migraine attack }\end{array}$ & 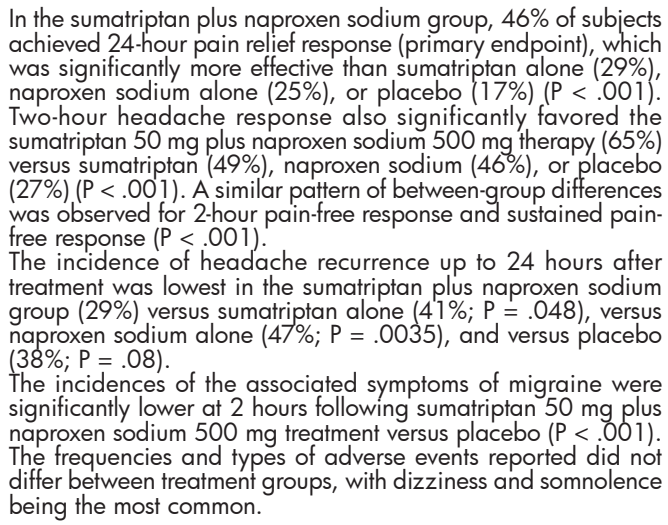 \\
\hline Solomon et al. ${ }^{188}$ & $\begin{array}{l}\text { Adults - Zolmitriptan } 2.5 \mathrm{mg} \\
40.7 \pm 11.26 \text {-Placebo } 40.2 \pm \\
11.84 \text { years } \\
n=301 \text { ( } 45 \text { male and } 256 \\
\text { female) }\end{array}$ & $\begin{array}{l}\text { Zolmitriptan } 2.5 \text { mg oral } \\
\text { Placebo } \\
\text { Single migraine attack }\end{array}$ & $\begin{array}{l}\text { Patients treated a single moderate or severe migraine headache } \\
\text { with } 2.5 \mathrm{mg} \text { zolmitriptan or placebo and recorded clinical } \\
\text { efficacy and adverse events on a diary form. Headache response } \\
\text { at } 2 \text { hours was } 62 \% \text { for zolmitriptan compared with } 36 \% \text { for } \\
\text { placebo ( }<<0.001 \text { ). At } 4 \text { hours, headache response was } 70 \% \\
\text { with zolmitriptan and } 37 \% \text { with placebo }(p<0.001) \text {. Headache } \\
\text { recurrence in patients treated with } 2.5 \text { mg zolmitriptan was } 22 \% \\
\text { (versus placebo } 30 \%) \text {. } \\
\text { The headache response at } 4 \text { hours, pain-free rate, and response } \\
\text { rate of nonheadache symptoms favored zolmitriptan over placebo. }\end{array}$ \\
\hline
\end{tabular}




\begin{tabular}{|c|c|c|c|}
\hline Spierings et al. ${ }^{189}$ & $\begin{array}{l}\text { Adults - mean age } 41.2 \pm 10.1 \\
\text { years (almotriptan) and } 40.3 \pm \\
10.1 \text { (Sumatriptan) } \\
n=1173 \text { ( } 129 \text { male and } 1044 \\
\text { female) }\end{array}$ & $\begin{array}{l}\text { Almotriptan } 12.5 \mathrm{mg} \text { capsule } \\
\text { oral } \\
\text { Sumatriptan } 50 \mathrm{mg} \text { capsule oral } \\
\text { Single migraine attack }\end{array}$ & $\begin{array}{l}\text { At } 2 \text { hours, almotriptan treatment provided headache relief in } \\
58.0 \% \text { of the subjects and sumatriptan treatment in } 57.3 \% \text {; } \\
\text { headache freedom was provided by the medications in } 17.9 \% \\
\text { and } 24.6 \% \text {, respectively }(P=.005) \text {. } \\
\text { Rescue medications were taken by } 36.7 \% \text { of the subjects in the } \\
\text { almotriptan-treated group and by } 33.2 \% \text { in the sumatriptan- } \\
\text { treated group; headaches returned to moderate or severe intensity } \\
\text { in } 27.4 \% \text { and } 24.0 \% \text {, respectively. } \\
\text { Treatment-emergent adverse events occurred in } 15.2 \% \text { of the } \\
\text { subjects in the almotriptan-treated group and in } 19.4 \% \text { in the } \\
\text { sumatriptan-treated group }(P=.06) \text {; treatment-related adverse } \\
\text { events occurred in } 9.1 \% \text { and } 15.5 \% \text { of the subjects, respectively } \\
(P=.001) \text {, including chest pain, which occurred in } 0.3 \% \text { and } \\
2.2 \% \text {, respectively }(P=.004) \text {. }\end{array}$ \\
\hline Spierings et al. ${ }^{190}$ & $\begin{array}{l}\text { Adults - mean age } 42 \text { years } \\
n=670 \text { (female } 580 \text { and male } \\
90 \text { ) }\end{array}$ & $\begin{array}{l}\text { Zolmitriptan } 5 \text { mg ODT } \\
\text { Placebo } \\
\text { Two migraine headaches }\end{array}$ & $\begin{array}{l}\text { Zolmitriptan } 5 \mathrm{mg} \text { ODT was significantly more effective than } \\
\text { placebo in achieving a headache response (reduction in migraine } \\
\text { headache intensity from moderate or severe to mild or no pain) } \\
\text { at } 30 \text { minutes ( } 16.5 \% \text { vs } 12.5 \% ; p=0.048 \text {; primary endpoint), } \\
1 \text { hour ( } p<0.0001 \text { ), and } 2 \text { hours ( } p<0.0001 \text { ). } \\
\text { Significantly more patients achieved a sustained headache } \\
\text { response for } 24 \text { hours with zolmitriptan } 5 \mathrm{mg} \text { ODT than with } \\
\text { placebo ( } 42.5 \% \text { vs } 16.4 \% \text {; } p<0.0001) \text {. Zolmitriptan } 5 \mathrm{mg} \\
\text { ODT also produced a higher pain-free rate than placebo at all } \\
\text { timepoints ( } 0.5,1 \text { and } 2 \text { hours post-dose), with the differences } \\
\text { becoming significant at } 1 \text { hour. }\end{array}$ \\
\hline $\begin{array}{l}\text { Spierings, } \\
\text { Keywood } 191\end{array}$ & $\begin{array}{l}\text { Adults - } 18 \text { to } 65 \text { years } \\
n=496 \text { ( } 58 \text { male and } 438 \\
\text { female) }\end{array}$ & $\begin{array}{l}\text { Frovatriptan } 2.5 \mathrm{mg} \text { oral } \\
\text { Placebo } \\
\text { 24-hour period }\end{array}$ & $\begin{array}{l}\text { With regard to the first attack treated, } 173(36 \%) \text { of the } 486 \\
\text { subjects in the study did not take a second dose at } 2 \text { hours for } \\
\text { nonresponse. At } 2 \text { hours and } 4 \text { hours, these "rapid responders" } \\
\text { experienced a decrease in headache intensity from moderate } \\
\text { or severe to mild or no pain in } 84 \% \text { and } 98 \% \text {, respectively } \\
\text { ("headache response"). Six percent of them experienced a } \\
\text { recurrence of moderate or severe headache within } 24 \text { hours } \\
\text { following a response at } 4 \text { hours and } 12 \% \text { took rescue medication. }\end{array}$ \\
\hline Stark et al. ${ }^{192}$ & $\begin{array}{l}\text { Adults - mean age } 41.7 \pm 8.7 \\
\text { years } \\
n=347 \text { (female: } 312 \text { and male: } \\
35 \text { ) }\end{array}$ & $\begin{array}{l}\text { Sumatriptan } 50 \mathrm{mg} \text { oral during } \\
\text { attack } 1 \\
\text { Naratriptan } 2.5 \mathrm{mg} \text { oral during } \\
\text { attack } 2 \\
\text { Placebo } \\
\text { Two migraine attacks }\end{array}$ & $\begin{array}{l}\text { Attack 1: About two thirds of this selected migraine population did } \\
\text { not respond to sumatriptan. Attack } 2: \text { Naratriptan was statistically } \\
\text { superior to placebo for headache relief at } 2 \text { hours and } 4 \text { hours, } \\
\text { as well as for most other features of migraine attacks. These data } \\
\text { suggest an intrinsic efficacy of naratriptan in this patient subset } \\
\text { and not a coincidental response. No unexpected tolerability } \\
\text { issues arose. }\end{array}$ \\
\hline Steiner et al. ${ }^{194}$ & $\begin{array}{l}\text { Adults - Eletriptan } 40 \mathrm{mg} \text { - } \\
40.3 \pm 10.4(19-64) \text { years; } \\
\text { Eletriptan } 80 \mathrm{mg}-40.4 \pm 10.5 \\
\text { (18-64) years; Zolmitriptan } 2.5 \\
\mathrm{mg}-40.1 \pm 10.5(18-64) \text { years; } \\
\text { Placebo - } 39.9 \pm 10.6 \text { (19-61) } \\
\text { years. } \\
\mathrm{n}=1337 \text { (203 male and } 1134 \\
\text { female) }\end{array}$ & $\begin{array}{l}\text { Eletriptan } 80 \mathrm{mg} \\
\text { Eletriptan } 40 \mathrm{mg} \\
\text { Zolmitriptan } 2.5 \mathrm{mg} \\
\text { Placebo } \\
\text { Single migraine attack }\end{array}$ & $\begin{array}{l}\text { The primary analysis was between eletriptan } 80 \mathrm{mg} \text { and } \\
\text { zolmitriptan. For the primary efficacy endpoint of } 2-\mathrm{h} \text { headache } \\
\text { response, rates were } 74 \% \text { on eletriptan } 80 \mathrm{mg}, 64 \% \text { on eletriptan } \\
40 \mathrm{mg}, 60 \% \text { on zolmitriptan ( } P<0.0001 \mathrm{vs} \text {. eletriptan } 80 \mathrm{mg} \text { ) } \\
\text { and } 22 \% \text { on placebo ( } P<0.0001 \text { vs. all active treatments) } \\
\text { Eletriptan } 80 \mathrm{mg} \text { was superior to zolmitriptan on all secondary } \\
\text { endpoints at } 1,2 \text { and } 24 \mathrm{~h} \text {, in most cases with statistical } \\
\text { significance. Eletriptan } 40 \mathrm{mg} \text { had similar efficacy to zolmitriptan } \\
2.5 \mathrm{mg} \text { in earlier endpoints, and significantly ( }<0.05) \text { lower } \\
\text { recurrence rate and need for rescue medication over } 24 \mathrm{~h} \text {. } \\
\text { All treatments were well tolerated: } 30-42 \% \text { of patients on active } \\
\text { treatments and } 40 \% \text { on placebo reported all-causality adverse } \\
\text { events that were mostly mild and transient. }\end{array}$ \\
\hline Stronks et al. ${ }^{33}$ & $\begin{array}{l}\text { Adults - } 42.2 \text { years (SD 9.8; } \\
\text { range, } 20 \text { to } 59 \text { ). } \\
n=12 \text { patients }\end{array}$ & $\begin{array}{l}\text { Naratriptan } 2.5 \mathrm{mg} \text { tablet } \\
\text { Naproxen } 500 \mathrm{mg} \text { capsule } \\
\text { To treat } 2 \text { migraine attacks }\end{array}$ & $\begin{array}{l}\text { During the first hours after intake of the study medication, the } \\
\text { objective behavioral parameeters showed no significant effect } \\
\text { time and no significant differences between naproxen and } \\
\text { naratriptan, but naratriptan showed improve of symptoms and } \\
\text { the interval between treatment and relief was significantly shorter } \\
\text { after intake of naratriptan. }\end{array}$ \\
\hline
\end{tabular}




\begin{tabular}{|c|c|c|c|}
\hline Talabi et al. ${ }^{195}$ & $\begin{array}{l}\text { Sumatriptan }-26.8 \text { (SD } 4) \\
\text { Metoclopramide }-34.9 \text { (SD 9) } \\
n=124 \text { ( } 77 \text { male and } 47 \\
\text { female) }\end{array}$ & $\begin{array}{l}\text { Sumatriptan } 6 \mathrm{mg} \text { SC } \\
\text { Metoclopramide } 20 \mathrm{mg} \text { IV } \\
\text { Single migraine attack }\end{array}$ & $\begin{array}{l}\text { At time } 0 \text { and } 60 \text { min, pain score with metoclopramide group } \\
\text { were } 6.74 \pm 0.84 \text { and } 0.66 \pm 0.59 \text {, respectively, according to } \\
\text { the result of paired t-test. The other group showed similar results: } \\
\text { baseline painscore in sumatriptan group was } 6.12 \pm 0.73 \text { that } \\
\text { decreased to } 1.1 \pm 0.70 \text { after } 60 \text { min of treatment. } \\
\text { Analysis with ANCOVA showed that the mean difference in } \\
\text { T60 pain score between the two groups was } 0.55 \pm 0.13(95 \% \\
\mathrm{Cl}: 0.25-0.79 \mathrm{~cm}) \text {. This difference was statistically significant } \\
(\mathrm{P}<0.001) \text {. }\end{array}$ \\
\hline Teall et al. ${ }^{196}$ & $\begin{array}{l}\text { Adults - Rizatriptan } 10 \mathrm{mg} 40.7 \\
\pm 9.6 \text {; Rizatriptan } 5 \mathrm{mg} 40.5 \pm \\
9.6 \text {; Placebo } 40.6 \pm 10.5 \text { years } \\
\mathrm{n}=1218 \text { (1055 female and } \\
163 \text { male) }\end{array}$ & $\begin{array}{l}\text { Rizatriptan } 10 \text { and } 5 \mathrm{mg} \text { oral } \\
\text { Placebo } \\
\text { One migraine attack }\end{array}$ & $\begin{array}{l}\text { The primary efficacy endpoint was the percentage of responders } \\
\text { at } 2 \text { hours after the initial dose. } \\
\text { Response rates at } 2 \text { hours - Rizatriptan } 62 \% 5 \mathrm{mg} \text { vs } 71 \% 10 \mathrm{mg} \\
\text { vs } 35 \% \text { placebo ( } \mathrm{P}<0.001) \text {. } \\
\text { Pain-free at } 1 \mathrm{~h} \text { - Rizatriptan } 5 \mathrm{mg} 33 \% \text { vs } 10 \mathrm{mg} 42 \% \text { vs Placebo } \\
10 \% \text {.Recurrence - Rizatriptan } 44 \% 5 \mathrm{mg} \text { vs } 47 \% 10 \mathrm{mg} \text { vs } 40 \% \\
\text { placebo. }\end{array}$ \\
\hline Tepper et al. ${ }^{197}$ & $\begin{array}{l}\text { Adults - mean age } 41.3(12-70 \\
\text { years) } \\
n=2,800(2,399 \text { female and } \\
401 \text { male })\end{array}$ & $\begin{array}{l}\text { Zolmitriptan } 2.5 \text { and } 5 \mathrm{mg} \\
\text { tablets } \\
\text { Placebo }\end{array}$ & $\begin{array}{l}\text { The two-hour pain-free response rate was higher in patients who } \\
\text { treated persistent headache of any intensity with any dose of } \\
\text { zolmitriptan compared with placebo. However, there were no } \\
\text { statistical differences between the two-hour headache response } \\
\text { rate for } 5 \mathrm{mg}, 2,5 \mathrm{mg} \text { of zolmitriptan or placebo. }\end{array}$ \\
\hline Tepper et al. ${ }^{198}$ & $\begin{array}{l}\text { Adults - Placebo: } 37.8 \pm 12.0 \text {; } \\
\text { Sumatriptan } 25 \text { mg: } 37.9 \pm \\
11.6 ; \text { Sumatriptan } 50 \text { mg: } 39.1 \\
\pm 12.2 \text { and Sumatriptan } 100 \\
\text { mg: } 39.3 \pm 11.4 \text { years. } \\
\mathrm{n}=400 \text { (female } 295 \text { and male } \\
105 \text { ) }\end{array}$ & $\begin{array}{l}\text { Sumatriptan } 25 \mathrm{mg}, 50 \mathrm{mg} \text {, } \\
100 \mathrm{mg} \text { tablets } \\
\text { Placebo } \\
\text { Single headache }\end{array}$ & $\begin{array}{l}\text { At } 2 \text { hours, more patients treated with sumatriptan achieved } \\
\text { headache relief, the primary efficacy measure, compared with } \\
\text { placebo, but differences only approached statistical significance } \\
\text { for } 100 \mathrm{mg}(\mathrm{P}=.053) \text {. The } 2 \text {-hour headache relief rate in the } \\
\text { sumatriptan } 25 \text { or } 50 \mathrm{mg} \text { groups was not significantly different } \\
\text { than placebo. } \\
\text { The time to use of rescue was significantly shorter in the placebo } \\
\text { group compared with the sumatriptan } 100 \mathrm{mg} \text { group ( } \mathrm{P}=.002) \text {. } \\
\text { The time to use of rescue in the sumatriptan } 25 \text { or } 50 \mathrm{mg} \text { groups } \\
\text { was not significantly different than placebo. } \\
\text { More patients treated with placebo }(22 \%) \text { lost headache relief } \\
\text { within } 4 \text { hours compared with patients treated with sumatriptan } \\
25 \mathrm{mg}(17 \%), 50 \mathrm{mg}(14 \%) \text {, or } 100 \mathrm{mg}(7 \%) \text {. }\end{array}$ \\
\hline $\begin{array}{l}\text { Tfelt-Hansen et } \\
\text { al. }{ }^{199}\end{array}$ & $\begin{array}{l}\text { Adults - mean age (range): } \\
\text { Placebo } 39 \text { (18-63); LAS+MTC } \\
40(18-62) ; \text { Sumatriptan } 39 \\
(18-58) \\
\mathrm{n}=421 \text { (female } 327 \text { and male } \\
94)\end{array}$ & $\begin{array}{l}\text { Lysine acetylsalicylate oral } \\
\text { (equivalent to } 900 \mathrm{mg} \text { aspirin) } \\
\text { and } 10 \mathrm{mg} \text { metoclopramide } \\
\text { (LAS+MTC) } \\
\text { Sumatriptan } 100 \mathrm{mg} \text { oral } \\
\text { Placebo } \\
\text { Two consecutive attacks with } \\
\text { moderate or severe headache }\end{array}$ & $\begin{array}{l}\text { LAS }+ \text { MTC was as effective as sumatriptan with a decrease of } \\
\text { headache from severe or moderate to mild or none of } 57 \% \text { and } \\
53 \% \text {, respectively, for the first migraine attack treated. } \\
\text { Both treatments were better than placebo (success rate } 24 \% \text {, } \\
\text { p }<0,0001 \text { ). LAS }+ \text { MTC was significantly more effective in the } \\
\text { treatment of nausea than sumatriptan ( } p<0,0001 \text { ) and was } \\
\text { better tolerated (adverse events in } 18 \% \text { and } 28 \% \text {, respectively, } \\
p<0 ; 05) .\end{array}$ \\
\hline $\begin{array}{l}\text { Tfelt-Hansen et } \\
\text { al. }{ }^{200}\end{array}$ & $\begin{array}{l}\text { Adults - } 18 \text { to } 65 \text { years, mean } \\
\text { age: } \\
\text { Placebo }-38.3 \pm 10.3 ; \\
\text { Rizatliptan } 5 \mathrm{mg}-38.3 \pm 10.3 \\
\text { Rizatriptan } 10 \mathrm{mg} 37.0 \pm 10.0 ; \\
\text { Sumatriptan } 100 \mathrm{mg} 39.2 \pm \\
10.1 \text {. } \\
\mathrm{n}=1099 \text { (898 female and } 201 \\
\text { male) }\end{array}$ & $\begin{array}{l}\text { Rizatriptan } 10 \mathrm{mg} \\
\text { Rizatriptan } 5 \mathrm{mg} \\
\text { Sumatriptan } 100 \mathrm{mg} \\
\text { Placebo } \\
\text { Oral }\end{array}$ & $\begin{array}{l}\text { Headache relief rates after rizatriptan } 10 \mathrm{mg} \text { were consistently } \\
\text { higher than sumatriptan at all time points up to } 2 \text { hours, with } \\
\text { significance at } 1 \text { hour }(37 \% \text { versus } 28 \%, P=0.010) \text {. All active } \\
\text { agents were significantly superior to placebo with regard to } \\
\text { headache relief and pain freedom at } 2 \text { hours }(P<\text { or }=0.001) \text {. } \\
\text { The primary efficacy endpoint of time to pain relief through } 2 \\
\text { hours demonstrated that, after adjustment for age imbalance, } \\
\text { rizatriptan } 10 \mathrm{mg} \text { had earlier onset than sumatriptan } 100 \mathrm{mg} \text { ( } P \\
=0.032 \text {; hazard ratio } 1.21) \text {. Rizatriptan } 10 \mathrm{mg} \text { was also superior } \\
\text { to sumatriptan on pain-free response }(P=0.032) \text {, reduction in } \\
\text { functional disability }(P=0.015) \text {, and relief of nausea at } 2 \text { hours } \\
(P=0.010) \text {. } \\
\text { Significantly fewer drug-related clinical adverse events were } \\
\text { reported after rizatriptan } 10 \mathrm{mg}(33 \%, P=0.014) \text { compared } \\
\text { with sumatriptan } 100 \mathrm{mg}(41 \%) \text {. }\end{array}$ \\
\hline $\begin{array}{l}\text { Tfelt-Hansen et } \\
\text { al. }{ }^{201}\end{array}$ & $\begin{array}{l}\text { Adults - Male - Plac } 48 \text { (SD } \\
10) / \text { Sum } 40 \text { (SD 12); Female } \\
\text { - Plac } 36 \text { (SD 1 1)/ Sum } 36 \\
\text { (SD 9) } \\
\text { n=101 (22 male and } 79 \\
\text { female) }\end{array}$ & $\begin{array}{l}\text { Sumatripan } 50 \mathrm{mg} \\
\text { Placebo } \\
\text { Single migraine attack }\end{array}$ & $\begin{array}{l}\text { Pain-free at } 2 \mathrm{~h} \text { - Sumatriptan } 20 / 51 \text { (39\%) vs Placebo } 8 / 45 \\
\text { (18\%) [difference } 21 \% ; 95 \% \text { confidence interval }(\mathrm{Cl}):+4 \%- \\
+39 \% ; \mathrm{p}=0.03 \text {, Fisher's exact test] }\end{array}$ \\
\hline $\begin{array}{l}\text { The oral } \\
\text { Sumatriptan } \\
\text { and Aspirin plus } \\
\text { Metoclopramide } \\
\text { Comparative } \\
\text { Study Group }\end{array}$ & $\begin{array}{l}\text { Adults - Sumatriptan } \\
\text { 100mg: } 42 \pm 12 ; \text { Aspirin }+ \\
\text { metoclopramide: } 39 \pm 11 \text { years } \\
\mathrm{n}=355 \text { ( } 283 \text { female and } 72 \\
\text { male) }\end{array}$ & $\begin{array}{l}\text { Sumatriptan ODT } 100 \mathrm{mg} \\
\text { Aspirin } 900 \mathrm{mg}+ \\
\text { metoclopramide } 10 \mathrm{mg} \text { oral } \\
\text { Up to three migraine attacks }\end{array}$ & $\begin{array}{l}\text { The primary efficacy analisys was based on headache relief } \\
\text { for attack } 1 \text { from grande } 3 \text { or } 2 \text { to grade } 0 \text { or } 1 \text { after } 2 \mathrm{~h} \\
\text { Pain relief } 2 \mathrm{~h} \text { after attack } \\
1 \text { - Sumatriptan - } 74 / 113(56 \%) \text { vs Aspirin+metoclopramide - } \\
62 / 138(45 \%)(p=0,078 \mathrm{NS}) \text {. Pain-free - Sumatriptan } 26 \% \text { vs } \\
\text { Aspirin+metoclopramide } 14 \% \text { ( } p=0.016) \\
\text { Pain relief } 2 \mathrm{~h} \text { after attack } 2 \text { - Sumatriptan - } 58 \% \text { vs } \\
\text { Aspirin+metoclopramide - } 36 \%(p=0.001) \text {. Pain-free - Sumatriptan } \\
23 \% \text { vs Aspirin+metoclopramide } 15 \% \text { ( } \mathrm{p}=\mathrm{NS} \text { ). } \\
\text { Pain relief } 2 \mathrm{~h} \text { after attack } 3 \text { - Sumatriptan - } 65 \% \text { vs } \\
\text { Aspirin+metoclopramide - } 34 \% \text { ( } \mathrm{p}<0,001) \text {. Pain-free - } \\
\text { Sumatriptan } 34 \% \text { vs Aspirin+metoclopramide } 12 \% \text { ( }<0.001) \text {. } \\
\text { Both treatments are equally effective at reducing nausea. There } \\
\text { was no difference between treatments in the number of patients } \\
\text { vomiting. Photophobia and phonophobia were relieved equally } \\
\text { well within } 2 \mathrm{~h} \text { by both treatments. }\end{array}$ \\
\hline
\end{tabular}




\begin{tabular}{|c|c|c|c|}
\hline $\begin{array}{l}\text { The Oral } \\
\text { Sumatriptan } \\
\text { International } \\
\text { Multiple-Dose } \\
\text { Study Group }{ }^{203}\end{array}$ & $\begin{array}{l}\text { Adults - Placebo: } 40 \pm 10 \text {; } \\
\text { Sumatriptan: } 42 \pm 10 \text { years } \\
n=232 \text { ( } 34 \text { male and } 198 \\
\text { female) }\end{array}$ & $\begin{array}{l}\text { Sumatriptan ODT 100mg } \\
\text { Placebo }\end{array}$ & $\begin{array}{l}\text { Patients who received sumatriptan showed a significantly } \\
(\mathrm{p}<0.001) \text { greater improvement in headache relief compared } \\
\text { with the placebo group } 2 \mathrm{~h} \text { after treatment }(50 \mathrm{vs} 19 \% \text {, } \\
\text { respectively) and more patients were pain-free (headache grade } \\
0 \text { ) in sumatriptan group at } 2 \mathrm{~h}(25 \mathrm{vs} 5 \% \text { ) and at } 4 \mathrm{~h}(48 \mathrm{vs} 13 \%) \text {. } \\
\text { AT } 2 \mathrm{~h} \text { fewer patients in the sumatriptan group experienced } \\
\text { nausea, vomiting, photophobia/phonophobia. Headache } \\
\text { recurred in } 48 \% \text { of patients receiving placebo and in } 42 \% \text { of } \\
\text { sumatriptan-treated patients within } 24 \mathrm{~h} \text { of the initial resolution } \\
\text { headache. } \\
\text { Adverse events were reported by } 38 \% \text { of patients in the } \\
\text { sumatriptan-treated group compared with } 23 \% \text { in the placebo } \\
\text { group }(p=0.019) \text {. }\end{array}$ \\
\hline $\begin{array}{l}\text { The Sumatriptan } \\
\text { Auto-Injector } \\
\text { Study Group } \\
{ }^{204}\end{array}$ & $\begin{array}{l}\text { Adults - mean age } 41 \text { years } \\
n=235 \text { ( } 192 \text { female and } 43 \\
\text { male) }\end{array}$ & $\begin{array}{l}\text { Sumatriptan } 6 \text { mg SC } \\
\text { Placebo } \\
\text { Single migraine attack }\end{array}$ & $\begin{array}{l}\text { The primary measure of treatment efficacy was based on a } \\
\text { comparison of the number of patients in the two treatment } \\
\text { groups who had a reduction in headache severity from severe } \\
\text { or moderate to mild or none at } 1 \text { and } 2 \mathrm{~h} \text {. At } 1 \mathrm{~h}, 77 \% \text { of } \\
\text { patients treating with } 6 \mathrm{mg} \text { sumatriptan compared to } 26 \% \text { treating } \\
\text { with placebo ( }<0.001 \text { ) had mild headache or none. At } 2 \mathrm{~h} \text {, } \\
\text { the response rates for all patients had risen to } 83 \text { and } 30 \% \text {, } \\
\text { respectively. } \\
\text { Of those patients requiring a second dose at } 1 \mathrm{~h} \text {, improvement } \\
\text { to mild or no headache at } 2 \mathrm{~h} \text { was achieved in } 61 \% \text { of patients } \\
\text { receiving sumatriptan compared to } 15 \% \text { of those receiving } \\
\text { placebo. }\end{array}$ \\
\hline Tietjen et al. ${ }^{35}$ & $\begin{array}{l}\text { Adults }-36.7 \text { years (range } 24 \text { to } \\
52 \text { years) } \\
n=15 \text { (female only) }\end{array}$ & $\begin{array}{l}\text { Naratriptan } 2.5 \mathrm{mg} \text { oral }+ \\
\text { Prochlorperazine } 25 \mathrm{mg} \text { rectal } \\
\text { suppository } \\
\text { Naratriptan } 2.5 \mathrm{mg} \text { oral }+ \\
\text { placebo } \\
\text { Multiple migraine attack }\end{array}$ & $\begin{array}{l}\text { Reduction in headache severity was observed at } 2 \text { hours }(P< \\
.001) \text { and at } 4 \text { hours }(P<.001) \text { from headache onset, with no } \\
\text { difference between the two treatment regimens }(P=.34) \text {. A } \\
\text { significant decrease in clinical disability at } 2 \text { hours }(P<.001) \text { and } \\
\text { at } 4 \text { hours }(P<.001) \text { was observed, with no difference between } \\
\text { the two treatment regimens }(P=.28) \text {. The pain-free state at } 4 \\
\text { hours was reported in a higher proportion with the naratriptan/ } \\
\text { placebo regimen ( } 50 \% \text { vs } 25 \%) \text {, but the trial size would need to } \\
\text { be doubled to significantly prove the endpoints. } \\
\text { Resolution of adverse effects was similar with both regimens at } 2 \\
\text { hours and at } 4 \text { hours, although nausea resolved more often for } \\
\text { those using the naratriptan/prochlorperazine regimen. }\end{array}$ \\
\hline Touchon et al. ${ }^{205}$ & $\begin{array}{l}\text { Adults - mean age } 42 \pm 10 \\
\text { years } \\
n=266 \text { ( } 36 \text { male and } 230 \\
\text { female) }\end{array}$ & $\begin{array}{l}\text { Sumatriptan } 6 \mathrm{mg} \text { SC } \\
\text { Dihydroergotamine (DHE) nasal } \\
\text { spray ( } 1 \mathrm{mg} \text { plus optional } 1 \mathrm{mg} \text { ) } \\
\text { Placebo } \\
\text { Two migraine attack }\end{array}$ & $\begin{array}{l}\text { Patients took SC sumatriptan for one attack and DHE nasal spray } \\
\text { for the other in random order. Data from both treatment periods } \\
\text { show that at all time points from } 15 \text { minutes, SC sumatriptan } \\
\text { was significantly better than DHE nasal spray at providing both } \\
\text { headache relief (moderate / severe headache improving to mild } \\
\text { / none) and resolution of headache. Similarly, SC sumatriptan } \\
\text { was superior to DHE nasal spray for the other efficacy end points } \\
\text { assessed in the study } \\
\text { Patients reported that both treatments were well tolerated. Adverse } \\
\text { events were reported by } 43 \% \text { of patients taking SC sumatriptan } \\
\text { and } 22 \% \text { of patients taking DHE nasal spray, and these were } \\
\text { usually mild and transient. }\end{array}$ \\
\hline Tuchman et al. 206 & $\begin{array}{l}\text { Adults - Zolmitriptan: } 38.3 \\
(20-51) \text {; Placebo: } 38.7 \text { (20-53) } \\
\text { years } \\
n=334 \text { (Female only) }\end{array}$ & $\begin{array}{l}\text { Zolmitriptan } 2.5 \mathrm{mg} \text { tablet oral } \\
\text { Placebo } \\
\text { Menstrual migraine attacks }\end{array}$ & $\begin{array}{l}\text { Primary efficacy endopoint was headache response at } 2 \\
\text { hours after initial treatment, using a } 4 \text {-point severity scale. } \\
2 \text {-hour response: Zolmitriptan }-65.7 \% \text { vs Placebo }-31.8 \% \\
\text { ( }<<0.0001) \text {. } \\
4 \text {-hour response: Zolmitriptan }-81.7 \% \text { vs Placebo }-57.9 \% \\
\text { (p<0.0001). } \\
\text { Adverse events: Zolmitriptan }-62.9 \% \text { vs placebo } 26.7 \% \text { - majority } \\
\text { were mild or moderare intensity. }\end{array}$ \\
\hline Tullo et al. ${ }^{207}$ & $\begin{array}{l}\text { Adults - mean age } 38.3 \pm 9.9 \\
\text { years. } \\
n=107 \text { ( } 85 \text { female and } 22 \\
\text { male) }\end{array}$ & $\begin{array}{l}\text { Frovatripan } 2.5 \mathrm{mg} \\
\text { Zolmitriptan } 2.5 \mathrm{mg} \\
\text { Three migraine attacks }\end{array}$ & $\begin{array}{l}\text { Patients ( } 77 \% \text { ) expressed a preference for a triptan. } \\
\text { Average preference - Frovatriptan }-2.9 \pm 1.3 \text { vs Zolmitriptan - } 3.0 \\
\pm 1.3 \text {. } \\
\text { common reasons - Rapid activity ( } 83 \% \mathrm{~F} \text { vs } 72 \% \mathrm{Z} \text { ), reduction } \\
\text { of headache severity ( } 53 \mathrm{~F} \text { vs } 42 \% \mathrm{Z} \text { ) and no side efffects ( } 40 \\
\mathrm{~F} \text { vs } 40 \% \mathrm{Z} \text { ). }\end{array}$ \\
\hline Tullo et al. ${ }^{34}$ & $\begin{array}{l}\text { Adults }-38.6 \pm 10 \\
\mathrm{n}=314 \text { ( } 272 \text { female and } 42 \\
\text { male) }\end{array}$ & $\begin{array}{l}\text { Frovatriptan } 2.5 \mathrm{mg} \\
\text { Frovatriptan } 2.5 \mathrm{mg}+ \\
\text { dexketoprofen } 25 \mathrm{mg} \\
\text { (FroDex25) } \\
\text { Frovatriptan } 2.5 \mathrm{mg}+ \\
\text { dexketoprofen } 37.5 \mathrm{mg} \\
\text { (FroDex } 37.5 \text { ) } \\
\text { oral } \\
\text { At least one migraine attack }\end{array}$ & $\begin{array}{l}\text { The proportions of subjects without pain at two hours (primary } \\
\text { endpoint) were } 29 \%(27 / 93) \text { with Frovatriptam alone compared } \\
\text { with } 51 \% \text { (48/95 FroDex } 25 \text { and } 46 / 91 \text { FroDex } 37.5) \text { with each } \\
\text { combination therapies }(p<0.05) \text {. } \\
\text { FroDex } 25 \text { and FroDex } 37.5 \text { showed a similar efficacy both for } \\
\text { primary and secondary endpoints. It seems there is no dose } \\
\text { response curve for the addition of dexketoprofen. }\end{array}$ \\
\hline Tulunay et al. ${ }^{34}$ & $\begin{array}{l}\text { Adults - mean age } 32.7 \pm 8.7 \\
\text { years. } \\
n=56 \text { ( } 47 \text { female and } 9 \text { male) }\end{array}$ & $\begin{array}{l}\text { Dipyrone } 1 \mathrm{~g} \mathrm{mg} \text { ( } 2 \text { tablets of } \\
500 \mathrm{mg} \text { ) oral } \\
\text { Placebo }\end{array}$ & $\begin{array}{l}\text { Total pain relief and pain relief were primary outcomes. } \\
\text { Pain relief at } 2 \mathrm{~h} \text { - Dipyrone } 59 / 112(52.7 \%) \text { vs Placebo } 13 / 56 \\
(23.2 \%)(\mathrm{p}<0,01) \text {. At } 4 \mathrm{~h} \text { - Dypirone } 64 / 112(57.1 \%) \text { vs Placebo } \\
16 / 56(28.6 \%)(\mathrm{p}<0.001) \text {. } \\
\text { Total pain relief at } 2 \mathrm{~h} \text { - Dypirone } 42 / 112(37.5 \%) \text { vs Placebo } \\
6 / 56(10.7 \%)(\mathrm{p}<0.001) \text {. At } 4 \mathrm{~h}-\text { Dipyrone } 45 / 112(40.2 \%) \\
\text { vs Placebo } 7 / 56(12.5 \%) \text { ( } \mathrm{p}<0.001) \text {. } \\
\text { Pain recurrence atter total pain relief - Dipyrone } 16.7 \%(7 / 42 \\
\text { attacks) and Placebo } 33.3 \% \text { ( } 2 / 6 \text { attacks). }\end{array}$ \\
\hline
\end{tabular}




\begin{tabular}{|c|c|c|c|}
\hline Visser et al. ${ }^{208}$ & $\begin{array}{l}\text { Adults - Placebo: } 39 \text { (SD 10); } \\
\text { Sumatriptan 1mg: } 41 \text { (SD } 11) ; \\
\text { Sumatriptan 2mg: } 40 \text { (SD } 11) ; \\
\text { Sumatriptan 3mg: } 39 \text { (SD 10). } \\
\text { n=685 (165 male and } 520 \\
\text { female) }\end{array}$ & $\begin{array}{l}\text { Sumatripan } 1,2 \text { and } 3 \mathrm{mg} \mathrm{SC} \\
\text { Placebo } \\
\text { One migraine attack }\end{array}$ & $\begin{array}{l}\text { By } 30 \text { minutes post dose } 17 \% \text { (95\% Cl } 8 \% \text { to } 27 \% \text { ) more patients } \\
\text { had improved with } 1 \mathrm{mg} \text { sumatriptan, } 22 \%(95 \% \mathrm{Cl} 13 \% \text { to } \\
32 \% \text { ) with } 2 \mathrm{mg} \text { sumatriptan and } 34 \%(95 \% \mathrm{Cl} 24 \% \text { to } 44 \%) \\
\text { with } 3 \mathrm{mg} \text { sumatriptan than with placebo (p < } 0.001 \text { for all } \\
\text { three comparisons versus placebo). The number of patients who } \\
\text { were improved increased significantly with increasing dose ( } \mathrm{p} \\
<0.002 \text {; chi-square test for trend). Complete resolution of pain } \\
\text { was obtained at } 30 \text { min by } 5 \% \text { of placebo-treated patients, } 9 \% \\
\text { of patients treated with } 1 \mathrm{mg} \text { sumatriptan and by } 14 \% \text { treated } \\
\text { with } 2 \text { mg or } 3 \text { mg sumatriptan, respectively. }\end{array}$ \\
\hline Visser et al. ${ }^{209}$ & $\begin{array}{l}\text { Adults - range: } 18 \text { to } 55 \text { years } \\
\text { [Placebo: } 39 \pm 9 \text { years; Riza- } \\
\text { 10mg: } 40 \pm 9 \text { years; Riza- } 20 \mathrm{mg} \text { : } \\
40 \pm 8 \text { years; Riza- } 40 \mathrm{mg}-41 \pm 9 \\
\text { years; Suma- } 100 \mathrm{mg}: 41 \pm 10 \\
\text { years;] } \\
\text { n=449 (402 female and } 47 \\
\text { male) }\end{array}$ & $\begin{array}{l}\text { Rizatriptan } 10,20,40 \mathrm{mg} \\
\text { Sumatriptan succinate } 100 \mathrm{mg} \\
\text { Placebo } \\
\text { oral } \\
\text { One migraine attack }\end{array}$ & $\begin{array}{l}\text { The proportion of patients with headache relief was } 18 \% \text { for } \\
\text { placebo; } 46 \% \text { for sumatriptan; and } 52 \% \text { for } 10 \text {-mg, } 56 \% \text { for } 20 \text { - } \\
\text { mg, and } 67 \% \text { for } 40 \text {-mg rizatriptan. All differences with placebo } \\
\text { were statistically significant }(\mathrm{P}<.001) \text {, and } 40 \text {-mg rizatriptan was } \\
\text { superior to sumatriptan }(\mathrm{P}=.01) \text {. } \\
\text { The proportion of patients who became free of pain at } 2 \text { hours } \\
\text { was } 3 \% \text { for the placebo-treated group; } 22 \% \text { for the sumatriptan- } \\
\text { treated group; and } 26 \%, 35 \% \text {, and } 47 \% \text { for the group of } \\
\text { patients who took the } 10-, 20-\text {, and } 40 \text {-mg doses of rizatriptan, } \\
\text { respectively (all differences with placebo, } \mathrm{P}<.005 ; 40 \text {-mg } \\
\text { rizatripan vs sumatriptan, } \mathrm{P}=.001) \text {. } \\
\text { The recurrence of headache within } 24 \text { hours was found to be } \\
\text { equal across all treatment groups-approximately } 40 \% \text {. Adverse } \\
\text { events (most commonly short-lasting mild or moderate dizziness } \\
\text { and drowsiness) occurred more frequently after a } 40 \text {-mg dose of } \\
\text { rizatriptan was given than after other treatments. }\end{array}$ \\
\hline Visser et al. ${ }^{53}$ & $\begin{array}{l}\text { Adolescents - Rizatiptan } 14.3 \\
\text { (SD 1.7) / Placebo - } 14.1 \text { (SD } \\
1.8) \text { years } \\
\mathrm{n}=476 \text { ( } 264 \text { female and } 212 \\
\text { male) }\end{array}$ & $\begin{array}{l}\text { Rizatriptan } 5 \mathrm{mg} \text { oral } \\
\text { Placebo } \\
\text { Single attack }\end{array}$ & $\begin{array}{l}\text { Primary efficacy measure was } 2 \mathrm{~h} \text { pain relief: Rizatriptan } 68.2 \% \\
\text { vs Placebo } 68.8 \% \text { ( } \mathrm{P}=\mathrm{NS}) \text {. Considering just patients who treated } \\
\text { migraine on weekend - Rizatriptan } 74 \% \text { vs Placebo } 58.3 \% \\
(\mathrm{p}=0.022) \text {. There was no difference in adverse events - Rizatriptan } \\
34.3 \% \text { vs Placebo } 30.2 \% \text {. }\end{array}$ \\
\hline $\begin{array}{l}\text { Wang, Fuh, } \\
\text { Wu2lo. }\end{array}$ & $\begin{array}{l}\text { Adults - Sumatriptan 20mg: } \\
37.0 \pm 10.8 \text { years; Placebo: } \\
37.4 \pm 9.8 \text { years. } \\
n=56 \text { ( } 48 \text { female and } 8 \text { male) }\end{array}$ & $\begin{array}{l}\text { Sumatriptan } 20 \mathrm{mg} \text { spray } \\
\text { Placebo spray }\end{array}$ & $\begin{array}{l}\text { A significant difference in headache relief rates between the } 2 \\
\text { groups was observed at } 30 \text { minutes postdose ( } 46 \% \text { vs. } 21 \% \text {, } \\
\mathrm{p}<0.05) \text {. One-hour postdose, } 61 \% \text { of sumatriptan recipients } \\
\text { experienced headache relief compared with } 43 \% \text { of placebo } \\
\text { recipients ( } p=0.181) \text {. The difference in relief rates between } \\
\text { groups diminished over time, mainly due to a high placebo } \\
\text { response ( } 54 \% \text { at } 2 \text { hours postdose). } \\
\text { Nausea, photophobia and phonophobia were alleviated in } \\
\text { the majority of patients in the sumatriptan nasal spray group, } \\
\text { although the benefit in comparison to placebo did not reach } \\
\text { statistical significance. } \\
\text { Most of the adverse events reported in the sumatriptan group were } \\
\text { mild and transient, and none were considered serious. }\end{array}$ \\
\hline Wells, Steiner ${ }^{211}$ & $\begin{array}{l}\text { Adults - mean age } 18-29 \\
(13.9 \%) ; 30-45(48.7 \%) ;>45 \\
(37.4 \%) \text { years } \\
n=674(565 \text { female and } 109 \\
\text { male) }\end{array}$ & $\begin{array}{l}\text { Eletriptan } 40 \mathrm{mg} \\
\text { Eletriptan } 80 \mathrm{mg} \\
\text { Placebo }\end{array}$ & $\begin{array}{l}\text { Patients receiving either dose of the active compound were unable } \\
\text { to perform their usual activities for a median period of } 4 \text { hours } \\
\text { compared with } 9 \text { hours experienced by those taking placebo. This } \\
\text { difference was highly statistically significant }(p<0.001) \text {. The time } \\
\text { saving associated with eletriptan usage reflected the differences } \\
\text { in efficacy findings in the clinical component of the study. }\end{array}$ \\
\hline Wendt et al. ${ }^{212}$ & $\begin{array}{l}\text { Adults - Sumatriptan } 4 \mathrm{mg}: 38.3 \\
\text { (SD } 9.5 \text { - Range 18-59) Placebo } \\
-38.1 \text { (SD } 9.7 \text { - Range 18-59) } \\
\mathrm{n}=577 \text { (501 female and } 76 \\
\text { male) }\end{array}$ & $\begin{array}{l}\text { Sumatriptan } 4 \mathrm{mg} \text { SC } \\
\text { Placebo SC } \\
\text { Single migraine attack }\end{array}$ & $\begin{array}{l}\text { The primary efficacy measurement was pain relief at } 2 \text { hours. } \\
\text { Pain relief at } 2 \mathrm{~h} \text { : Sumatriptan } 4 \mathrm{mg}-70 \%(\mathrm{n}=268) \text { and Placebo } \\
-22 \%(\mathrm{n}=42)(P<0.001) \text {. Pain free at } 2 \mathrm{~h} \text { : Sumatriptan }-50 \% \\
(\mathrm{n}=192) \text { and placebo }-11 \%(\mathrm{n}=21)(\mathrm{P}<0.001) \text {. } \\
\text { Use of rescue medication: Placebo }-45 \%(\mathrm{n}=86) \text { Sumatriptan } \\
-22 \%(\mathrm{n}=84) \text {. } \\
\text { Adverse events: Sumatriptan - } 66 \%(\mathrm{n}=265) \text { and Placebo }-39 \% \\
(n=75)(P<0.001) \text {. }\end{array}$ \\
\hline Winner et al. ${ }^{213}$ & $\begin{array}{l}\text { Adults - DHE- } 45: 40.5 \pm 8.6 \\
\text { years and range of } 20 \text { to } 63 \\
\text { years; sumatriptan: } 41.5 \text { years } \\
\text { and range of } 22 \text { to } 59 \text { years. } \\
n=310 \text { ( } 272 \text { females and } 38 \\
\text { males) }\end{array}$ & $\begin{array}{l}\text { Dihydroergotamine mesylate } \\
\text { (DHE- } 45 \text { ) } 1 \mathrm{mg} \text { SC } \\
\text { Sumatriptan succinate } 6 \mathrm{mg} \mathrm{SC} \\
\text { Single migraine attack }\end{array}$ & $\begin{array}{l}\text { At } 2 \text { hours, } 73.1 \% \text { of the patients treated with dihydroergotamine } \\
\text { and } 85.3 \% \text { of those treated with sumatriptan had relief }(P=.002) \text {. } \\
\text { There was no statistical difference in headache relief between the } \\
\text { groups at } 3 \text { or } 4 \text { hours. Headache relief was achieved by } 85.5 \% \\
\text { of those treated with dihydroergotamine and by } 83.3 \% \text { of those } \\
\text { treated with sumatriptan by } 4 \text { hours. } \\
\text { By } 24 \text { hours } 89.7 \% \text { of dihydroergotamine-treated patients and } \\
76.7 \% \text { of sumatriptan-treated patients had relief }(P=.004) \text {. } \\
\text { Headache recurred within } 24 \text { hours after treatment in } 45 \% \\
\text { of the sumatriptan-treated patients and in } 17.7 \% \text { of the } \\
\text { dihydroergotamine-treated patients }(P \leq .001) \text {. }\end{array}$ \\
\hline
\end{tabular}




\begin{tabular}{|c|c|c|c|}
\hline Winner et al. ${ }^{54}$ & $\begin{array}{l}\text { Adolescents - } 14.1 \pm 1.6(12 \text { to } \\
17) \text { years; [Placebo }-14.2 \pm 1.6 \text {, } \\
\text { Suma-5mg } 14.1 \pm 1.7 \text {, Suma- } \\
10 \mathrm{mg} 14.0 \pm 1.6 \text {, Suma-20mg } \\
14.0 \pm 1.6] \\
\mathrm{n}=510 \text { ( } 250 \text { male and } 260 \\
\text { female) }\end{array}$ & $\begin{array}{l}\text { Sumatriptan } 5 \mathrm{mg}, 10 \mathrm{mg} \text {, or } \\
20 \mathrm{mg} \text { nasal spray } \\
\text { Placebo }\end{array}$ & $\begin{array}{l}\text { Headache relief } 1 \text {-hour postdose was significantly greater for } \\
\text { patients using } 10 \mathrm{mg}(56 \%) \text { and } 20 \mathrm{mg}(56 \%) \text { of sumatriptan } \\
\text { nasal spray compared with placebo (4l\%). Headache relief } 2 \\
\text { hours postdose was significantly greater for patients using } 5 \\
\text { mg of sumatriptan nasal spray ( } 66 \%) \text { compared with placebo } \\
(53 \%) \text { and approached statistical significance for } 20 \mathrm{mg}(63 \%) \\
\text { compared with placebo (53\%). Complete relief } 2 \text { hours postdose } \\
\text { was significantly greater for patients using } 20 \mathrm{mg} \text { of sumatriptan } \\
\text { nasal spray compared with placebo ( } 36 \% \text { vs } 25 \% \text {, respectively). } \\
\text { Photophobia and phonophobia were significantly reduced } 2 \\
\text { hours postdose for sumatriptan nasal spray ( } 20 \text { mg), compared } \\
\text { with placebo ( } 36 \% \text { vs } 48 \% \text { and } 25 \% \text { vs } 44 \% \text { respectively). Taste } \\
\text { disturbance was the most commonly reported adverse event }(2 \% \text {, } \\
19 \%, 30 \% \text {, and } 26 \% \text { for placebo, } 5 \text { mg, } 10 \text { mg, and } 20 \text { mg, } \\
\text { respectively). No drug-related serious adverse events or clinically } \\
\text { relevant changes were reported. }\end{array}$ \\
\hline Winner et al..$^{55}$ & $\begin{array}{l}\text { Adolescents - mean age } 14 \\
\text { years } \\
n=296 \text { (161 female and } 135 \\
\text { male) }\end{array}$ & $\begin{array}{l}\text { Rizatriptan } 5 \mathrm{mg} \text { oral } \\
\text { Placebo }\end{array}$ & $\begin{array}{l}\text { The percentage of patients pain-free at } 2 \text { hours was } 32 \% \text { for } \\
\text { rizatriptan } 5 \mathrm{mg} \text { versus } 28 \% \text { for placebo (P.474). The percentage } \\
\text { of patients with pain relief (reduction of predose pain intensity to } \\
\text { mild or none) at } 2 \text { hours was } 66 \% \text { for rizatriptan versus } 56 \% \text { for } \\
\text { placebo (P.079). Compared with placebo, rizatriptan significantly } \\
\text { improved functional disability at } 1.5 \text { and } 2 \text { hours, and nausea } \\
\text { at } 1 \text { and } 1.5 \text { hours. } \\
\text { Rizatriptan } 5 \mathrm{mg} \text { was well tolerated. The most commonly reported } \\
\text { adverse events among patients receiving rizatriptan were dry } \\
\text { mouth, dizziness, asthenia/fatigue, nausea, and somnolence. }\end{array}$ \\
\hline Winner et al. ${ }^{28}$ & $\begin{array}{l}\text { Adults - mean age } 40.3 \\
\text { years (aged 18-65 years) - } \\
\text { Placebo: } 40.7 \pm 10.5 \text { years; } \\
\text { Sumatriptan- } 50 \mathrm{mg}: 39.8 \pm 10.5 \\
\text { years; sumatriptan- } 100 \mathrm{mg} \\
40.5 \pm 10.0 \text { years. } \\
\mathrm{n}=354 \text { ( } 311 \text { females and } 43 \\
\text { male) }\end{array}$ & $\begin{array}{l}\text { Sumatriptan } 50 \mathrm{mg} \text { and } 100 \\
\text { mg tablets } \\
\text { Placebo } \\
\text { Single migraine attack }\end{array}$ & $\begin{array}{l}\text { Significantly more patients treated with sumatriptan, } 100 \text { mg and } \\
50 \text { mg were pain-free relief at } 2 \text { and } 4 \text { hours after treatment vs } \\
\text { patients treated with placebo (at } 2 \text { hours, } 53 \% \text { and } 48 \% \text { vs } 29 \% \text {; } \\
\text { at } 4 \text { hours, } 71 \% \text { and } 66 \% \text { vs } 32 \% \text {; for both, } P<.001 \text { ). } \\
\text { Also, significantly more patients treated with sumatriptan } 50 \mathrm{mg} \\
\text { and } 100 \mathrm{mg} \text { were migraine-free (no pain or associated symptoms) } \\
\text { vs those treated with placebo at } 2 \text { and } 4 \text { hours after treatment (at } \\
2 \text { hours, } 41 \% \text { and } 48 \% \text { vs } 25 \% \text {; at } 4 \text { hours, } 58 \% \text { and } 66 \% \text { vs } \\
30 \% \text {; for both, } P<.001 \text { ). The incidence of overall adverse events } \\
\text { was low with the } 50-\text { and } 100 \text {-mg dose of sumatriptan (placebo, } \\
8 \% \text {; sumatriptan at } 50 \mathrm{mg}, 18 \% \text {; sumatriptan at } 100 \text { mg, } 19 \% \text { ). }\end{array}$ \\
\hline Winner et al. ${ }^{28}$ & $\begin{array}{l}\text { Adults - mean } 42.6 \text { years } \\
\text { (aged } 18-65 \text { years) - } \\
\text { Placebo: } 42.7 \pm 9.8 \text { years; } \\
\text { Sumatriptan- } 50 \mathrm{mg}: 43.5 \pm 10.4 \\
\text { years; sumatriptan- } 100 \mathrm{mg} \\
41.7 \pm 11.0 \text { years. } \\
\mathrm{n}=337 \text { ( } 298 \text { females and } 39 \\
\text { males) }\end{array}$ & $\begin{array}{l}\text { Sumatriptan } 50 \mathrm{mg} \text { and } 100 \\
\text { mg tablets } \\
\text { Placebo } \\
\text { Single migraine attack }\end{array}$ & $\begin{array}{l}\text { Significantly more patients treated with sumatriptan } 100 \mathrm{mg} \\
\text { and } 50 \mathrm{mg} \text {, with pain-free relief at } 2 \text { and } 4 \text { hours after treatment } \\
\text { vs patients treated with placebo (at } 2 \text { hours, } 62 \% \text { and } 53 \% \text { vs } \\
29 \% \text {; at } 4 \text { hours, } 65 \% \text { and } 55 \% \text { vs } 30 \% \text {; for both, } P<.001 \text { ). The } \\
\text { incidence of overall adverse events was low with the } 50 \text { - and } \\
100 \text {-mg dose of sumatriptan (placebo, 6\%; sumatriptan at } 50 \\
\text { mg, } 9 \% \text {; sumatriptan at } 100 \mathrm{mg}, 12 \% \text { ). }\end{array}$ \\
\hline Winner et al. ${ }^{47}$ & $\begin{array}{l}\text { Adults - Sumatriptan: } 40.2 \text { (SD } \\
9.7 \text { )/Placebo: } 41.1 \text { (SD 10.4) } \\
\text { years } \\
n=297 \text { ( } 247 \text { female and } 50 \\
\text { male) }\end{array}$ & $\begin{array}{l}\text { Sumatriptan 6mg SC } \\
\text { Placebo }\end{array}$ & $\begin{array}{l}\text { Pain-free } 2 \mathrm{~h} \text { : Sumatriptan }-48 \% \text { vs Placebo } 18 \%(\mathrm{P}<0.001) \text {. } \\
\text { Headache relief } 2 \mathrm{~h} \text { : Sumatriptan } 72 \% \text { vs Placebo } 32 \%(\mathrm{P}< \\
0.001) \text {. }\end{array}$ \\
\hline Winner et al. ${ }^{47}$ & $\begin{array}{l}\text { Adults - Sumatriptan: } 38.8 \text { (SD } \\
10.1) \text { / Placebo: } 39.3 \text { (SD } 9.7 \text { ) } \\
\mathrm{n}=287 \text { ( } 38 \text { male and } 249 \\
\text { female) }\end{array}$ & $\begin{array}{l}\text { Sumatriptan 6mg SC } \\
\text { Placebo }\end{array}$ & $\begin{array}{l}\text { Pain-free } 2 \mathrm{~h} \text { : Sumatriptan }-57 \% \text { vs Placebo } 19 \%(\mathrm{P}<0.001) \text {. } \\
\text { Headache relief } 2 \mathrm{~h} \text { : Sumatriptan } 77 \% \text { vs Placebo } 41 \%(\mathrm{P}< \\
0.001) \text {. }\end{array}$ \\
\hline Winner et al. ${ }^{45}$ & $\begin{array}{l}\text { Adolescents - Sumatriptan } \\
\text { 20mg: } 14.3 \pm 1.8(12-18) ; \\
\text { Sumatriptan } 5 \mathrm{mg}: 14.3 \pm 1.6 \\
(12-18) ; \text { Placebo: } 14.2 \pm 1.7 \\
(11-17) \text {; } \\
\text { n=731 (400 female and } 331 \\
\text { male) }\end{array}$ & $\begin{array}{l}\text { Sumatriptan } 20 \text { and } 5 \mathrm{mg} \text { Nasal } \\
\text { Spray } \\
\text { Placebo } \\
\text { Single migraine attack }\end{array}$ & $\begin{array}{l}\text { The primary efficacy endpoints were headache relief rates at } \\
1 \text { hour and sustained relief rates from } 1 \text { to } 24 \text { hours postdose. } \\
\text { Headache relief at } 1 \mathrm{~h} \text { : Sum nasal spray } 20 \mathrm{mg}-61 \% \text { vs Sum } \\
\text { nasal spray } 5 \mathrm{mg}-53 \% \text { vs Placebo - } 52 \% \text { ( } \mathrm{p}=0.087) \text {. } \\
\text { Pain-free headache } 2 \mathrm{~h} \text { : Sum nasal spray } 20 \mathrm{mg}-44 \% \text { vs Placebo } \\
30 \% \text { ( } \mathrm{p}<0.001) \text {. Sustained relief } 1-24 \mathrm{~h} \text { - Sum nasal spray } 20 \mathrm{mg} \\
-41 \% \text { vs Sum nasal spray } 5 \mathrm{mg}-37 \% \text { vs Placebo } 32 \% \text { (P=NS). } \\
\text { Overall incidence of adverse events in each treatment group }(8 \% \\
\text { placebo; } 26 \% \text { sumatriptan nasal spray } 5 \mathrm{mg} ; 33 \% \text { sumatriptan } \\
\text { nasal spray } 20 \mathrm{mg} \text { ). }\end{array}$ \\
\hline Winner et al. ${ }^{46}$ & $\begin{array}{l}\text { Adolescents - Eletriptan: } 14 \\
\pm 1.65 \text { years; Placebo: } 14 \pm \\
1.65 \text { years } \\
\mathrm{n}=274 \text { ( } 157 \text { female and } 117 \\
\text { male) }\end{array}$ & $\begin{array}{l}\text { Eletriptan } 40 \mathrm{mg} \text { oral } \\
\text { Placebo } \\
\text { Single migraine attack }\end{array}$ & $\begin{array}{l}\text { The primary outcome measure was } 2 \text {-hour headache response. } \\
\text { Headache response rates were almost identical on eletriptan } 40 \\
\text { mg and placebo by } 2 \text { hours ( } 57 \% \text { vs } 57 \%) \text {. Pain-free rates were } \\
\text { also similar at } 2 \text { hours ( } 22 \% \text { vs } 15 \%) \text {. Absence of associated } \\
\text { symptoms at } 2 \text { hours eletriptan } 40 \text { mg and placebo, respectively, } \\
\text { for nausea }(75 \% \text { vs } 78 \%) \text {, photophobia }(62 \% \text { vs } 64 \%) \text {, and } \\
\text { phonophobia }(70 \% \text { vs } 67 \%) \text {. Use of rescue medication for } \\
\text { nonresponse was somewhat lower on eletriptan } 40 \text { mg than on } \\
\text { placebo ( } 32 \% \text { vs } 39 \%) \text {. } \\
\text { Significant differences in efficacy - } 24 \text {-hour outcomes measures: } \\
\text { sustained headache response }(52 \% \text { vs } 39 \% ; P<.005) \text { and } \\
\text { sustained pain-free response }(22 \% \text { vs } 10 \% ; P<.005) \text {. }\end{array}$ \\
\hline
\end{tabular}




\begin{tabular}{|c|c|c|c|}
\hline Winner et al. ${ }^{29}$ & $\begin{array}{l}\text { Adolescents - Zolmitriptan 5mg: } \\
14.5 \text { (SD 1.67); Zolmitriptan } \\
2.5 \mathrm{mg}: 14.6 \text { (SD1.77); } \\
\text { Zolmitriptan 0.5mg: } 14.5 \text { (SD } \\
1.72 \text { ); Placebo - } 14.3 \text { (SD } \\
1.67 \text { ). } \\
\text { n=798 (305 male and } 493 \\
\text { female) }\end{array}$ & $\begin{array}{l}\text { Zolmitriptan } 5,2.5 \text { and } 0.5 \mathrm{mg} \\
\text { nasal spray } \\
\text { Placebo } \\
\text { Single migraine attack }\end{array}$ & $\begin{array}{l}\text { The primary outcome variable is pain-freestatus } 2 \text { hours post- } \\
\text { treatment. } \\
\text { Pain-free } 2 \text { hours post treatment: Zolmitriptan nasal spray } 5 \mathrm{mg} \text { - } \\
68 / 229(29,7 \%) \text { vs Placebo } 42 / 253 \text { (OR } 2.18 ; 95 \% \mathrm{Cl} 1.40 \text {, } \\
3.39(16,6 \%)(\mathrm{P}<.001) \text {. } \\
\text { Headache response at } 2 \mathrm{~h} \text { : Zolmitriptan nasal spray } 5 \mathrm{mg} 51 \% \\
\text { [1 } 16 / 229] \text { vs Placebo } 39 \% \text { [99/253]; } \mathrm{P}=0.010 \text {. } \\
\text { Sustained headache response } 2 \mathrm{~h} \text { : Zolmitriptan (any dose) - } 30 \% \\
\text { (120/396) vs Placebo } 24 \%(59 / 251) \text { - not statistically significant. }\end{array}$ \\
\hline Zhang et al. ${ }^{214}$ & $\begin{array}{l}\text { Adults - Rizatriptan Group: } \\
36.6 \pm 12.8 \text { years; Propacetamol } \\
\text { group: } 35.6 \pm 10.8 \text { years. } \\
\mathrm{n}=148 \text { ( } 76 \text { female and } 72 \\
\text { male) }\end{array}$ & $\begin{array}{l}\text { Propacetamol }(1 \mathrm{~g}) \text { IV } \\
\text { Rizatriptan } 5 \mathrm{mg} \text { oral }\end{array}$ & $\begin{array}{l}\text { Propacetamol showed superior efficacy at } 1 \mathrm{~h} \text { and there was } \\
\text { no significant difference at } 30 \text { min or at } 2 \mathrm{~h} \text {. This indicates that } \\
\text { propacetamol is at least as effective as rizatriptan in the treatment } \\
\text { of acute migraine attacks. }\end{array}$ \\
\hline
\end{tabular}




\section{Discussion}

Our study suggests that overall response to triptans is as effective as that observed with dipyrone in acute migraine treatment.

Several studies involving triptans have evaluated the efficacy of different doses compared to placebo or included an evaluation of comparative efficacy between different triptans or doses. In general, all types of triptan were more effective than placebo in relieving migraine, with a good safety standard, although some drugs have achieved similar results as those for placebo. Attention to exceptional positive results for placebo in migraine treatment in some double-blind studies should be given, especially in the adolescent population. Symptoms related to migraine (nausea and vomiting, phonophobia and photophobia) also had a good response with triptans. In general, triptans were effective in relieving associated symptoms and reducing clinical disability compared to placebo. A poor response to one triptan does not predict a poor response to other agents belonging to the class.

Regarding dipyrone (metamizole) results, Bigal showed that the number of patients required to be treated with dipyrone $1 \mathrm{~g}$ by intravenous injection compared to placebo for at least one to benefit was 3.3 in 30 min and 2.2 in $60 \mathrm{~min}$. There were statistically significant reductions in recurrence (dipyrone $=25 \%$, placebo $=50 \%$ ) and use of rescue medication (dipyrone $=20 \%$, placebo $=47.6 \%$ ) for the dipyrone group. ${ }^{38}$

A few studies have evaluated the restoration of functional ability after a migraine crisis and, to a lesser extent, lost time from work. A good number of studies evaluated the possibility of returning to normal functions or the number of patients who were able to return to normal activities after an average of 2 hours from initial treatment for a migraine episode. All studies involved triptans and no study was performed with dipyrone. $24,35,36,55,68,69,73,85,129,130,135,140$, $143,145,152,161,166,177,211$

Barbanti et al evaluated equivalent work time loss after a migraine attack, and the results showed $1.9 \pm 2.3$ and $2.5 \pm 4.7$ hours lost from work for sumatriptan $100 \mathrm{mg}$ and $50 \mathrm{mg}$, respectively, compared with $3.5 \pm 4.3$ for placebo. Sumatriptan $100 \mathrm{mg}$ was also able to better restore functional ability. ${ }^{64}$

Freitag et al. (REF) evaluated normal function disability, bed rest required, and ER/hospitalization resulting from a migraine attack in order to compare almotriptan and placebo responses at $2 \mathrm{~h}$ - and $4 \mathrm{~h}$-posttreatment. The study showed that pain resolution was associated with a normal level of function, and the absence of photophobia, phonophobia, and nausea at 2 hours was also associated with less disability. In the study, treatment with almotriptan compared with placebo resulted in consistently better 24 hour quality of life scores, with restored social function. A logistic regression model determined that pretreatment functional level and pretreatment pain intensity were significant covariates of the proportion of patients who achieved normal function at 2 hours posttreatment. ${ }^{103}$

Dasbaci et al. ${ }^{84}$ demonstrated that rizatriptan decreased the total number of lost work hours by $1.1 \mathrm{~h}$ per treated migraine attack compared with placebo.

Most studies that evaluated migraine in the menstrual period involved triptans. 97, 159, 160, 185, 206 Silverstein et al. demonstrated that treatment results with rizatriptan in menstrual period migraine were similar compared to those for migraine unrelated to the menstrual period. ${ }^{185}$

Some studies have associated hormonal drugs and mainly NSAIDs with the use of triptan in one of the tested arms, with good therapeutic results in general, especially when there was an association of a triptan with a NSAID, with superior results when compared to the drug alone. Naproxen, ketoprofen and ibuprofen were the most common NSAIDs evaluated in the studies. ${ }^{20}, 30,33,34,48,86$, 106,187

Tullo et al. evaluated the factors that influenced the selection of a treatment for migraine, comparing frovatriptan and zolmitriptan in the selected study, and found the following order of priority: 1) speed of action; 2) reduction in pain intensity and 3) absence of side effects. ${ }^{207}$ On the other hand, Savi et al. ${ }^{178}$ demonstrated the following order of choice by patients: rapid speed of action, good tolerability and reduction in pain severity, being decisive for the selection of frovatriptan over rizatriptan. Although these studies have evaluated triptans, rapid pain relief appears to be the main attribute of drug selection for migraine relief. ${ }^{92,171,207}$

Regarding the question presented in this study: "what is the evidence for the efficacy and safety of metamizole for the treatment of migraines compared with triptans?" The result is that overall response to metamizole is as effective as that observed with triptans in acute migraine treatment. The second point of evaluation in this systematic review was: "how effective are those treatments in improving cognitive 
dysfunction in patients with migraine?" Unfortunately, cognitive improvement is not a goal evaluated in most studies included in the review. A few triptan studies showed that pain resolution was associated with a normal level of function, and also a logistic regression model determined that pretreatment functional level and pretreatment pain intensity were significant covariates of the proportion of patients who achieved normal function at 2 hours posttreatment. There are no data regarding cognitive dysfunction improvement related to metamizole utilization, so it may just be an inference related to metamizole.

This systematic review involved different forms of administration and doses of metamizole and triptans, which allowed us to have a complete and comprehensive view of studies involving both studied medications in migraine treatment, but limits some more direct comparisons between doses and routes of administration. Most studies performed with triptans utilized oral administration and most studies with metamizole in this review utilized the intravenous route of administration.

No direct comparisons between metamizole and triptans have been performed in a controlled and randomized clinical study and most studies involving triptans have been conducted in European countries and the US.

The main weakness of this systematic review and metaanalysis is the small number of studies involving metamizole included. The literature on metamizole is scarce. In the setting of the present analyses, only 5 articles with metamizole had a placebo arm and the estimates obtained were all indirect. This fact is directly related to the absence of drug availability in expressive markets, such as the US and some European countries. Studies with metamizole included in this review were limited to Brazil, Spain and Turkey. ${ }^{8,}$ 37, 39.42

Despite the adverse event of agranulocytosis being the main reason for metamizole withdrawal from the market in some countries, this health risk was not proven true in the pharmacovigilance data and other scientific evidence generated in countries that maintained product commercialization. ${ }^{215-217}$

The data did not show a significant difference between metamizole and triptans in neither pain relief nor pain absence 2 hours after medication. In support of relief within 24 hours after medication, eletriptan, rizatriptan and zolmitriptan showed statistically different proportions from metamizole. There is no evidence of a difference between metamizole and triptans in absence of pain 24 hours after medication.

Considering the equivalence of therapeutic benefit and adverse events with triptans, especially cardiovascular ones, in addition to pharmacoeconomic aspects, as metamizole is far cheaper than triptans, metamizole could be a good medicine option for migraine treatment.

\section{Conclusion}

Metamizole may be equally effective as triptans in acute migraine treatment, with a good tolerability profile and a potentially better cost-benefit ratio with significant implications to healthcare policies. More studies are necessary to confirm our results.

Conflict of interest statement: MP has received consultant fees from Sanofi, Lundbeck, Ache, Eurofarma, Libbs, Novartis, Eli Lilly, Allergan Abbvie, Teva, Hefesto Medtech. WS and RS are employees of Sanofi, Sanofi financed the study.

\section{Abbreviations}

AEs, adverse effects

Bid, twice daily

$\mathrm{Cl}$, Confidence Interval

$\mathrm{IV}$, intravenous

NS, nasal spray

NSAIDs, non-steroidal anti-inflammatory drugs

ODT, orally disintegrating tablet

PRISMA, Preferred Reporting Items for Systematic Reviews and Meta-Analyses Protocols

$\mathrm{qd}$, once daily

SC, subcutaneous

TDS: iontophoretic transdermal patch

US, United States

Authors' contributions: All Authors contributed equally to the conception, design, drafting and critical revisions of the manuscript. All authors read and approved the final manuscript.

Funding: This work was supported by Sanofi. Editorial support in the preparation of this publication was paid for by Sanofi. The authors, individually and collectively are responsible for all content and editorial decisions related to the development/presentation of this publication.

Mario Fernando Prieto Peres

https://orcid.org/0000-0002-0068-1905

Wanessa Alessandra Ruiz Scala 
https://orcid.org/0000-0003-3423-5222

Ricardo Salazar

https://orcid.org/0000-0002-3529-5254

\section{References}

1. Stewart WF, Shechter A and Lipton RB. Migraine heterogeneity. Disability, pain intensity, and attack frequency and duration. Neurology 1994;44(6 Suppl 4):S24-39

2. Rasmussen BK. Epidemiology of headache. Cephalalgia 1995;15(1):45-68 Doi:10.1046/ j. 1468-2982.1995.1501045.x

3. The International Classification of Headache Disorders: 2nd edition. Cephalalgia 2004;24 Suppl 1:9-160 Doi:10.1111/j.1468-2982.2003.00824.x

4. Dodick DW. A Phase-by-Phase Review of Migraine Pathophysiology. Headache 2018;58 Suppl 1:4-16 Doi:10.1111/head. 13300

5. Gil-Gouveia R and Martins IP. Cognition and Cognitive Impairment in Migraine. Curr Pain Headache Rep 2019;23(1 1):84 Doi:10.1007/s 1 1916-019-0824-7

6. Worthington I, Pringsheim T, Gawel MJ, Gladstone J, Cooper P, Dilli E, . . . Becker WJ. Canadian Headache Society Guideline: acute drug therapy for migraine headache. Can J Neurol Sci 2013;40(5 Suppl 3):S1s80

7. Bigal ME, Bordini CA and Speciali JG. Headache treatment in an emergency unit of the city of Ribeirão Preto, Brazil. Arq Neuropsiquiatr 1999;57(3b):813819 Doi:10.1590/s0004-282x1999000500013

8. Bigal ME, Bordini CA, Tepper SJ and Speciali JG. Intravenous dipyrone in the acute treatment of migraine without aura and migraine with aura: a randomized, double blind, placebo controlled study. Headache 2002;42(9):862-871 Doi:10.1046/ j. 1526-4610.2002.02204.x

9. González-Hernández A, Marichal-Cancino BA, MaassenVanDenBrink A and Villalón CM. Side effects associated with current and prospective antimigraine pharmacotherapies. Expert Opin Drug Metab Toxicol 2018;14(1):25-41 Doi:10.1080/17425255.2018.1 416097

10. Johnston $M M$ and Rapoport $A M$. Triptans for the management of migraine. Drugs 2010;70(12):15051518 Doi: $10.2165 / 11537990-000000000-00000$

11. Moher D, Shamseer L, Clarke M, Ghersi D, Liberati A, Petticrew $M, \ldots$ Stewart LA. Preferred reporting items for systematic review and meta-analysis protocols (PRISMA-P) 2015 statement. Syst Rev 2015;4(1):1 Doi:10.1186/2046-4053-4-1
12. Shamseer L, Moher D, Clarke M, Ghersi D, Liberati A, Petticrew $M, \ldots$ Stewart LA. Preferred reporting items for systematic review and meta-analysis protocols (PRISMA-P) 2015: elaboration and explanation. $B m i$ 2015;350g7647 Doi:10.1136/bmi.g7647

13. Hutton B, Salanti G, Caldwell DM, Chaimani A, Schmid CH, Cameron C, . . Moher D. The PRISMA extension statementfor reporting of systematic reviews incorporating network meta-analyses of health care interventions: checklist and explanations. Ann Intern Med 2015;162(11):777-784 Doi:10.7326/m142385

14. Higgins J GS. Cochrane Handbook for Systematic Reviews of Interventions [Internet]. 2011 [cited 2020 20 Aug]. Available from: https://training.cochrane. org/handbook/current.

15. Headache Classification Committee of the International Headache Society (IHS) The International Classification of Headache Disorders, 3rd edition. Cephalalgia 2018;38(1):1-211 Doi: $10.1177 / 0333102417738202$

16. Dias S, Welton NJ, Sutton AJ and Ades AE. NICE Decision Support Unit Technical Support Documents. NICE DSU Technical Support Document 2: A Generalised Linear Modelling Framework for Pairwise and Network Meta-Analysis of Randomised Controlled Trials. London: National Institute for Health and Care Excellence (NICE)Copyright (C) 2014 National Institute for Health and Clinical Excellence, unless otherwise stated. All rights reserved.; 2014.

17. Simmonds $M C$ and Higgins JP. A general framework for the use of logistic regression models in metaanalysis. Stat Methods Med Res 2016;25(6):28582877 Doi: $10.1177 / 0962280214534409$

18. Egger M, Davey Smith G, Schneider M and Minder C. Bias in meta-analysis detected by a simple, graphical test. Bmi 1997;315(7109):629-634 Doi:10.1136/ bmi.315.7109.629

19. Begg CB and Mazumdar M. Operating characteristics of a rank correlation test for publication bias. Biometrics 1994;50(4):1088-1 101

20. Brandes JL, Kudrow D, Stark SR, O'Carroll CP, Adelman JU, O'Donnell FJ, . . Lener SE. Sumatriptan-naproxen for acute treatment of migraine: a randomized trial. Jama 2007;297(13):1443-1454 Doi:10.1001/ jama. 297.13.1443

21. Cady RK, Wendt JK, Kirchner JR, Sargent JD, Rothrock JF and Skaggs H, Jr. Treatment of acute migraine with subcutaneous sumatriptan. Jama $1991 ; 265(21): 2831-2835$

22. Landy S, Savani N, Shackelford S, Loftus J and Jones $M$. Efficacy and tolerability of sumatriptan 
tablets administered during the mild-pain phase of menstrually associated migraine. Int J Clin Pract 2004;58(10):913-919 Doi: $10.1111 /$ j.1368$5031.2004 .00295 . x$

23. Mannix LK, Loder E, Nett R, Mueller L, Rodgers A, Hustad CM, .. . Skobieranda F. Rizatriptan for the acute treatment of ICHD-II proposed menstrual migraine: two prospective, randomized, placebo-controlled, double-blind studies. Cephalalgia 2007;27(5):414421 Doi:10.1111/j.1468-2982.2007.01313.x

24. Mushet GR, Cady RK, Baker CC, Clements B, Gutterman DL and Davis R. Efficacy and tolerability of subcutaneous sumatriptan administered using the IMITREX STATdose System. Clin Ther 1996; 18(4):687699 Doi:10.1016/s0149-2918(96)80219-0

25. Ryan R, Elkind A, Baker CC, Mullican W, DeBussey $S$ and Asgharnejad M. Sumatriptan nasal spray for the acute treatment of migraine. Results of two clinical studies. Neurology 1997;49(5):1225-1230 Doi:10.1212/wnl.49.5.1225

26. Ryan R, Géraud G, Goldstein J, Cady R and Keywood C. Clinical efficacy of frovatriptan: placebo-controlled studies. Headache 2002;42 Suppl 2(S84-92 Doi:10.1046/j.1526-4610.42.s2.6.x

27. Sheftell F, Ryan R and Pitman V. Efficacy, safety, and tolerability of oral eletriptan for treatment of acute migraine: a multicenter, double-blind, placebocontrolled study conducted in the United States. Headache 2003;43(3):202-213 Doi:10.1046/ j.1526-4610.2003.03043.x

28. Winner P, Mannix LK, Putnam DG, McNeal S, Kwong $J, O^{\prime} Q u i n n S$ and Richardson MS. Pain-free results with sumatriptan taken at the first sign of migraine pain: 2 randomized, double-blind, placebo-controlled studies. Mayo Clin Proc 2003;78(10):1214-1222 Doi:10.4065/78.10.1214

29. Winner P, Farkas V, Štillová H, Woodruff B, Liss C, Lillieborg $S$ and Raines $S$. Efficacy and tolerability of zolmitriptan nasal spray for the treatment of acute migraine in adolescents: Results of a randomized, double-blind, multi-center, parallel-group study (TEENZ). Headache 2016;56(7):1107-1119 Doi: $10.1111 /$ head. 12859

30. Diener HC, Bussone $G$, de Liano $H$, Eikermann A, Englert R, Floeter T, . . . Voelker M. Placebocontrolled comparison of effervescent acetylsalicylic acid, sumatriptan and ibuprofen in the treatment of migraine attacks. Cephalalgia 2004;24(1 1):947-954 Doi:10.1 111 /j.1468-2982.2004.00783.x

31. Klapper JA and O'Connor S. Rizatriptan wafer-sublingual vs. placebo at the onset of acute migraine. Cephalalgia 2000;20(6):585-587 Doi:10.1046/ i. 1468-2982.2000.00079.x

32. Silberstein S, Winner PK, McAllister PJ, Tepper SJ, Halker R, Mahmoud RA and Siffert J. Early Onset of Efficacy and Consistency of Response Across Multiple Migraine Attacks From the Randomized COMPASS Study: AVP-825 Breath Powered(囚) Exhalation Delivery System (Sumatriptan Nasal Powder) vs Oral Sumatriptan. Headache 2017;57(6):862-876 Doi: $10.1111 /$ head. 13105

33. Stronks DL, Tulen JH, Bussmann HB, Mulder $L$ and Passchier J. Effects of naratriptan versus naproxen on daily functioning in the acute treatment of migraine: a randomized, double-blind, double-dummy, crossover study. Headache 2003;43(8):845-852 Doi:10.1046/i.1526-4610.2003.03162.x

34. Tullo V, Valguarnera $F$, Barbanti $P$, Cortelli $P$, Sette $G$, Allais $G, \ldots$ Bussone $G$. Comparison of frovatriptan plus dexketoprofen $125 \mathrm{mg}$ or 37.5 $\mathrm{mg}$ ) with frovatriptan alone in the treatment of migraine attacks with or without aura: a randomized study. Cephalalgia 2014;34(6):434-445 Doi: $10.1177 / 0333102413515342$

35. Tietjen GE, Athanas K, Utley C, Herial NA and Khuder SA. The combination of naratriptan and prochlorperazine in migraine treatment. Headache 2005;45(6):751-753 Doi:10.1111/i.15264610.2005.05143_1.x

36. Freitag F, Diamond $M$, Diamond S, Janssen I, Rodgers $A$ and Skobieranda F. Efficacy and tolerability of coadministration of rizatriptan and acetaminophen vs rizatriptan or acetaminophen alone for acute migraine treatment. Headache 2008;48(6):921-930 Doi:10.1111/j.1526-4610.2007.01053.x

37. Bigal M, Sheftell F, Tepper S, Tepper D, Ho TW and Rapoport A. A randomized double-blind study comparing rizatriptan, dexamethasone, and the combination of both in the acute treatment of menstrually related migraine. Headache 2008;48(9):1286-1293 Doi:10.1111/i.15264610.2008.01092.x

38. Bigal ME, Bordini CA and Speciali JG. Intravenous dipyrone for the acute treatment of episodic tension-type headache: a randomized, placebocontrolled, double-blind study. Braz J Med Biol Res 2002;35(10):1139-1145 Doi:10.1590/s0100$879 \times 2002001000005$

39. Fernandes Filho SM, Costa MS, Fernandes MT and Foerster MV. Comparison of intravenous dipyrone to intravenous metoclopramide in the treatment of acute crisis of migraine: randomized clinical trial. Arq Neuropsiquiatr 2006;64(4):1005-1008 Doi:10.1590/s0004-282×2006000600023 
40. Krymchantowski AV, Carneiro H, Barbosa J and Jevoux C. Lysine clonixinate versus dipyrone (metamizole) for the acute treatment of severe migraine attacks: a single-blind, randomized study. Arq Neuropsiquiatr 2008;66(2a):216-220 Doi: 10.1590/s0004$282 \times 2008000200015$

41. Martínez-Martín P, Raffaelli E, Jr., Titus F, Despuig J, Fragoso YD, Díez-Tejedor E, . . . Ortiz P. Efficacy and safety of metamizol vs. acetylsalicylic acid in patients with moderate episodic tension-type headache: a randomized, double-blind, placeboand active-controlled, multicentre study. Cephalalgia $2001 ; 21(5): 604-610$ Doi:10.1046/i.14682982.2001.00216.x

42. Tulunay FC, Ergün $H$, Gülmez SE, Ozbenli T, Ozmenoğlu M, Boz C, . . . Inan L. The efficacy and safety of dipyrone (Novalgin) tablets in the treatment of acute migraine attacks: a double-blind, cross-over, randomized, placebo-controlled, multi-center study. Funct Neurol 2004; 19(3): 197-202

43. Ahonen K, Hämäläinen ML, Eerola M and Hoppu K. A randomized trial of rizatriptan in migraine attacks in children. Neurology 2006;67(7):1135-1140 Doi:10.1212/01.wnl.0000238179.79888.44

44. Ahonen K, Hämäläinen ML, Rantala $\mathrm{H}$ and Hoppu $K$. Nasal sumatriptan is effective in treatment of migraine attacks in children: $A$ randomized trial. Neurology 2004;62(6):883-887 Doi:10.1212/01. wnl.0000115105.05966.a7

45. Winner P, Rothner AD, Wooten JD, Webster C and Ames $M$. Sumatriptan nasal spray in adolescent migraineurs: a randomized, double-blind, placebocontrolled, acute study. Headache 2006;46(2):212222 Doi:10.1111/j.1526-4610.2006.00339.x

46. Winner $P$, Linder SL, Lipton RB, Almas $M$, Parsons $B$ and Pitman $V$. Eletriptan for the acute treatment of migraine in adolescents: results of a double-blind, placebo-controlled trial. Headache 2007;47(4):511518 Doi:10.1111/i.1526-4610.2007.00755.x

47. Winner P, Adelman J, Aurora S, Lener ME and Ames $M$. Efficacy and tolerability of sumatriptan injection for the treatment of morning migraine: two multicenter, prospective, randomized, double-blind, controlled studies in adults. Clin Ther 2006;28(10):1582-1591 Doi:10.1016/i.clinthera.2006.10.011

48. Evers S, Rahmann A, Kraemer C, Kurlemann G, Debus $\mathrm{O}$, Husstedt IW and Frese A. Treatment of childhood migraine attacks with oral zolmitriptan and ibuprofen. Neurology 2006;67(3):497-499 Doi:10.1212/01. wnl.0000231 138.18629.d5

49. Fujita M, Sato K, Nishioka H and Sakai F. Oral sumatriptan for migraine in children and adolescents: a randomized, multicenter, placebo-controlled, parallel group study. Cephalalgia 2014;34(5):365375 Doi:10.1177/0333102413510213

50. Hämäläinen $M L$, Hoppu $K$ and Santavuori $P$. Sumatriptan for migraine attacks in children: a randomized placebo-controlled study. Do children with migraine respond to oral sumatriptan differently from adults? Neurology 1997;48(4):1100-1103 Doi: 10.1212/wnl.48.4.1100

51. Ho TW, Pearlman E, Lewis $D$, Hämäläinen $M$, Connor K, Michelson D, . . . Hewitt DJ. Efficacy and tolerability of rizatriptan in pediatric migraineurs: results from a randomized, double-blind, placebocontrolled trial using a novel adaptive enrichment design. Cephalalgia 2012;32(10):750-765 Doi: $10.1177 / 0333102412451358$

52. Linder SL, Mathew NT, Cady RK, Finlayson G, Ishkanian $G$ and Lewis DW. Efficacy and tolerability of almotriptan in adolescents: a randomized, double-blind, placebo-controlled trial. Headache 2008;48(9):1326-1336 Doi:10.1111/i.15264610.2008.01138.x

53. Visser WH, Winner P, Strohmaier K, Klipfel M, Peng Y, McCarroll K, . . Nett R. Rizatriptan 5 mg for the acute treatment of migraine in adolescents: results from a double-blind, single-attack study and two open-label, multiple-attack studies. Headache 2004;44(9):891899 Doi:10.1111/i.1526-4610.2004.04171.x

54. Winner $P$, Rothner AD, Saper J, Nett R, Asgharnejad M, Laurenza A, . . . Peykamian M. A randomized, double-blind, placebo-controlled study of sumatriptan nasal spray in the treatment of acute migraine in adolescents. Pediatrics 2000; 106(5):989-997 Doi: 10.1542/peds. 106.5.989

55. Winner $P$, Lewis D, Visser WH, Jiang K, Ahrens S and Evans JK. Rizatriptan $\mathbf{5} \mathbf{~ m g}$ for the acute treatment of migraine in adolescents: a randomized, double-blind, placebo-controlled study. Headache 2002;42(1):4955 Doi:10.1046/i.1526-4610.2002.02013.x

56. $56 G$ R. Netmeta: Network Meta-Analysis using Frequentist Methods CRAN; 2021.Available from: https://cran.r-project.org/web/packages/netmeta/ netmeta.pdf.

57. Guido Schwarzer JRC, Gerta Rücker. Meta-Analysis with R. 3 ed: Springer, Cham; 2015.

58. Bomhof M, Paz J, Legg N, Allen C, Vandormael $\mathrm{K}$ and Patel $\mathrm{K}$. Comparison of rizatriptan $10 \mathrm{mg}$ vs. naratriptan $2.5 \mathbf{~ m g}$ in migraine. Eur Neurol 1999;42(3):173-179 Doi:10.1159/000008094

59. Bousser MG, D'Allens $H$ and Richard A. Efficacy of subcutaneous sumatriptan in the acute treatment of early-morning migraine: a placebo-controlled 
trial. Early-Morning Migraine Sumatriptan Study Group. J Intern Med 1993;234(2):211-216 Doi:10.1111/j.1365-2796.1993.tb00732.x

60. Cady RK, Dexter J, Sargent JD, Markley H, Osterhaus JT and Webster CJ. Efficacy of subcutaneous sumatriptan in repeated episodes of migraine. Neurology 1993;43(7):1363-1368 Doi:10.1212/ wnl.43.7.1363

61. Diamond S, Elkind A, Jackson RT, Ryan R, DeBussey $S$ and Asgharnejad M. Multiple-attack efficacy and tolerability of sumatriptan nasal spray in the treatment of migraine. Arch Fam Med 1998;7(3):234-240 Doi:10.1001/archfami.7.3.234

62. Klapper J, Lucas C, Røsjø $\varnothing$ and Charlesworth B. Benefits of treating highly disabled migraine patients with zolmitriptan while pain is mild. Cephalalgia 2004;24(11):918-924Ｄoi:10.1111/j.14682982.2004.00735 $x$

63. Klassen A, Elkind A, Asgharnejad M, Webster C and Laurenza A. Naratriptan is effective and well tolerated in the acute treatment of migraine. Results of a double-blind, placebo-controlled, parallelgroup study. Naratriptan S2WA3001 Study Group. Headache 1997;37(10):640-645 Doi:10.1046/ j. 1526-4610.1997.3710640.x

64. Lewis DW, Winner P, Hershey AD and Wasiewski WW. Efficacy of zolmitriptan nasal spray in adolescent migraine. Pediatrics 2007;120(2):390396 Doi:10.1542/peds.2007-0085

65. Loder E, Freitag FG, Adelman J, Pearlmand S and Abu-Shakra S. Pain-free rates with zolmitriptan $2.5 \mathrm{mg}$ ODT in the acute treatment of migraine: results of a large double-blind placebo- controlled trial. Curr Med Res Opin 2005;21(3):381-389 Doi:10.1185/030079905×28926

66. Massiou H, Jamin C, Hinzelin G and Bidaut-Mazel C. Efficacy of oral naratriptan in the treatment of menstrually related migraine. Eur I Neurol 2005;12(10):774-78 1 Doi: $10.1111 /$ j.1468 $1331.2005 .01076 . x$

67. Mathew NT, Schoenen J, Winner P, Muirhead N and Sikes CR. Comparative efficacy of eletriptan $40 \mathrm{mg}$ versus sumatriptan $100 \mathrm{mg}$. Headache 2003;43(3):214-222 Doi: $10.1046 /$ j.15264610.2003.03044.x

68. Misra UK, Kalita J and Yadav RK. Rizatriptan vs. ibuprofen in migraine: a randomised placebocontrolled trial. J Headache Pain 2007;8(3):175-179 Doi:10.1007/s 10194-007-0386-7

69. A placebo-controlled study of intranasal sumatriptan for the acute treatment of migraine. The Finnish Sumatriptan Group and the Cardiovascular Clinical
Research Group. Eur Neurol 1991;31(5):332-338 Doi:10.1159/000116761

70. Pascual J, Bussone G, Hernandez JF, Allen C, Vrijens $F$ and Patel K. Comparison of preference for rizatriptan $10-\mathrm{mg}$ wafer versus sumatriptan $50-\mathrm{mg}$ tablet in migraine. Eur Neurol 2001;45(4):275-283 Doi: $10.1159 / 000052143$

71. Santanello NC, Polis AB, Hartmaier SL, Kramer MS, Block GA and Silberstein SD. Improvement in migrainespecific quality of life in a clinical trial of rizatriptan. Cephalalgia 1997;17(8):867-872; discussion 800 Doi:10.1046/j. 1468-2982.1997.1708867.x

72. Wells NE and Steiner TJ. Effectiveness of eletriptan in reducing time loss caused by migraine attacks. Pharmacoeconomics 2000;18(6):557-566 Doi: 10.2165/00019053-200018060-00003

73. Barbanti P, Carpay JA, Kwong WJ, Ahmad F and Boswell D. Effects of a fast disintegrating/ rapid release oral formulation of sumatriptan on functional ability in patients with migraine. Curr Med Res Opin 2004;20(12):2021-2029 Doi: $10.1185 / 030079904 \times 15200$

74. Freitag F, Smith T, Mathew N, Rupnow M, Greenberg $S$, Mao $L, \ldots$. Biondi $D$. Effect of early intervention with almotriptan vs placebo on migraine-associated functional disability: results from the AEGIS Trial. Headache 2008;48(3):341-354 Doi:10.1111/ j. 1526-4610.2007.01044.x

75. Dasbach EJ, Carides GW, Gerth WC, Santanello NC, Pigeon JG and Kramer. Work and productivity loss in the rizatriptan multiple attack study. Cephalalgia 2000;20(9):830-834 Doi:10.1046/j.14682982.2000.00126.x

76. Dowson AJ, Massiou H and Aurora SK. Managing migraine headaches experienced by patients who self-report with menstrually related migraine: a prospective, placebo-controlled study with oral sumatriptan. J Headache Pain 2005;6(2):81-87 Doi:10.1007/s10194-005-0156-3

77. Nett R, Landy S, Shackelford S, Richardson MS, Ames $M$ and Lener $M$. Pain-free efficacy after treatment with sumatriptan in the mild pain phase of menstrually associated migraine. Obstet Gynecol 2003; 102(4):835-842 Doi:10.1016/s00297844(03)00659-8

78. Newman L, Mannix LK, Landy S, Silberstein S, Lipton RB, Putnam DG, . . O'Quinn S. Naratriptan as short-term prophylaxis of menstrually associated migraine: a randomized, double-blind, placebocontrolled study. Headache 2001;41(3):248-256 Doi:10.1046/i.1526-4610.2001.111006248.x

79. Silberstein SD, Massiou H, Le Jeunne C, Johnson- 
Pratt L, McCarroll KA and Lines CR. Rizatriptan in the treatment of menstrual migraine. Obstet Gynecol 2000;96(2):237-242 Doi:10.1016/s00297844(00)00880-2

80. Tuchman $M$, Hee $A$, Emeribe $U$ and Silberstein $S$. Efficacy and tolerability of zolmitriptan oral tablet in the acute treatment of menstrual migraine. CNS Drugs 2006;20(12):1019-1026 Doi:10.2165/00023210200620120-00005

81. Dib M, Massiou H, Weber M, Henry P, Garcia-Acosta $S$ and Bousser MG. Efficacy of oral ketoprofen in acute migraine: a double-blind randomized clinical trial. Neurology 2002;58(11):1660-1665 Doi:10.1212/ wnl.58.11.1660

82. Friedman BW, Solorzano C, Esses D, Xia S, Hochberg M, Dua N, . . . Gallagher EJ. Treating headache recurrence after emergency department discharge: a randomized controlled trial of naproxen versus sumatriptan. Ann Emerg Med 2010;56(1):7-17 Doi:10.1016/i.annemergmed.2010.02.005

83. Smith TR, Sunshine A, Stark SR, Littlefield DE, Spruill SE and Alexander WJ. Sumatriptan and naproxen sodium for the acute treatment of migraine. Headache 2005;45(8):983-991 Doi: $10.1111 /$ i.1526 4610.2005.05178.x

84. Tullo V, Allais G, Ferrari MD, Curone M, Mea E, Omboni $S$, . . . Bussone $G$. Frovatriptan versus zolmitriptan for the acute treatment of migraine: a double-blind, randomized, multicenter, Italian study. Neurol Sci 2010;31 Suppl 1(Suppl 1):S51-54 Doi:10.1007/s10072-010-0273-x

85. Savi L, Omboni S, Lisotto C, Zanchin G, Ferrari MD, Zava D and Pinessi L. A double-blind, randomized, multicenter, Italian study of frovatriptan versus rizatriptan for the acute treatment of migraine. J Headache Pain 201 1;12(2):219-226 Doi:10.1007/ s10194-010-0243-y

86. Díez Fl, Straube A and Zanchin G. Patient preference in migraine therapy. A randomized, open-label, crossover clinical trial of acute treatment of migraine with oral almotriptan and rizatriptan. J Neurol 2007;254(2):242-249 Doi:10.1007/s00415-0060352-3

87. Rapoport AM, Visser WH, Cutler NR, Alderton CJ, Paulsgrove LA, Davis RL and Ferrari MD. Oral sumatriptan in preventing headache recurrence after treatment of migraine attacks with subcutaneous sumatriptan. Neurology 1995;45(8):1505-1509 Doi:10.1212/wnl.45.8.1505

88. Kötter T, da Costa BR, Fässler M, Blozik E, Linde K, Jüni $P, \ldots$ Scherer M. Metamizole-associated adverse events: a systematic review and meta-analysis. PLOS
One 2015;10(4):e0122918 Doi:10.1371/journal. pone. 0122918

89. Hamerschlak N, Maluf E, Biasi Cavalcanti A, Avezum Júnior A, Eluf-Neto J, Passeto Falcão R, . . Pasquini R. Incidence and risk factors for agranulocytosis in Latin American countries--the Latin Study: a multicenter study. Eur J Clin Pharmacol 2008;64(9):921-929 Doi:10.1007/s00228-008-0513-7

90. Silva Dal Pizzol T, Turmina Fontanella A, Cardoso Ferreira MB, Bertoldi AD, Boff Borges $R$ and Serrate Mengue $S$. Analgesic use among the Brazilian population: Results from the National Survey on Access, Use and Promotion of Rational Use of Medicines (PNAUM). PloS One 2019;14(3):e0214329 Doi:10.1371/journal.pone.0214329

91. Ahrens SP, Farmer MV, Williams DL, Willoughby E, Jiang K, Block GA and Visser WH. Efficacy and safety of rizatriptan wafer for the acute treatment of migraine. Rizatriptan Wafer Protocol 049 Study Group. Cephalalgia 1999;19(5):525-530 Doi:10.1046/j. 1468-2982.1999.019005525.x

92. Akpunonu $B E$, Mutgi $A B$, Federman DJ, Volinsky FG, Brickman K, Davis RL, . . . Asgharnejad M. Subcutaneous sumatriptan for treatment of acute migraine in patients admitted to the emergency department: a multicenter study. Ann Emerg Med 1995;25(4):464-469 Doi:10.1016/s01960644(95)70259-8

93. Allais $G$, Acuto $G$, Benedetto C, D'Andrea G, Grazzi $L$, Manzoni GC, . . Bussone G. Evolution of migraineassociated symptoms in menstrually related migraine following symptomatic treatment with almotriptan. Neurol Sci 2010;31 Suppl 1(Suppl 1):S115-119 Doi:10.1007/s10072-010-0302-9

94. Allais G, Bussone G, D'Andrea G, Moschiano $F$, d'Onofrio $F$, Valguarnera $F$, . . . Acuto $G$. Almotriptan $12.5 \mathrm{mg}$ in menstrually related migraine: a randomized, double-blind, placebocontrolled study. Cephalalgia 2011;31(2):144-151 Doi: $10.1177 / 0333102410378048$

95. Almas M, Tepper SJ, Landy S, Schweizer E and Ramos E. Consistency of eletriptan in treating migraine: Results of a randomized, within-patient multipledose study. Cephalalgia 2014;34(2):126-135 Doi: $10.1177 / 0333102413500726$

96. Banerjee $M$ and Findley $L$. Sumatriptan in the treatment of acute migraine with aura. Cephalalgia 1992; 12(1):39-44 Doi: 10.1046/i.14682982.1992.1201039.x

97. Barbanti P, Fofi L, Dall'Armi V, Aurilia C, Egeo G, Vanacore $\mathrm{N}$ and Bonassi $\mathrm{S}$. Rizatriptan in migraineurs with unilateral cranial autonomic symptoms: a 
double-blind trial. J Headache Pain 2012;13(5):407414 Doi:10.1007/s10194-012-0440-y

98. Bartolini $M$, Giamberardino MA, Lisotto $C$, Martelletti P, Moscato D, Panascia B, . . . Fierro B. A doubleblind, randomized, multicenter, Italian study of frovatriptan versus almotriptan for the acute treatment of migraine. J Headache Pain 2011;12(3):361-368 Doi:10.1007/s10194-011-0325-5

99. Bigal ME, Lipton RB, Newman LC, Pierce MW and Silberstein SD. Sumatriptan lontophoretic Transdermal System Reduces Treatment-Emergent Nausea and Is Effective in Patients With and Without Nausea at Baseline - Results From a Randomized Controlled Trial. Headache 2015;55(8):1124-1132 Doi:10.1111/ head. 12606

100. Brandes JL, Kudrow D, Cady R, Tiseo PJ, Sun $W$ and Sikes CR. Eletriptan in the early treatment of acute migraine: influence of pain intensity and time of dosing. Cephalalgia 2005;25(9):735-742 Doi:10.1111/i.1468-2982.2005.00981.x

101. Brandes JL, Poole A, Kallela M, Schreiber CP, MacGregor EA, Silberstein SD, . . Shaw R. Shortterm frovatriptan for the prevention of difficultto-treat menstrual migraine attacks. Cephalalgia 2009;29(11):1133-1148～Doi:10.1111/j.14682982.2009.01840.x

102. Bussone G, Manzoni GC, Cortelli P, Roncolato $M$, Fabbri $L$ and Benassuti $C$. Efficacy and tolerability of sumatriptan in the treatment of multiple migraine attacks. Neurol Sci 2000;21(5):272-278 Doi: $10.1007 / \mathrm{s} 100720070064$

103. Cady R, Elkind A, Goldstein J and Keywood C. Randomized, placebo-controlled comparison of early use of frovatriptan in a migraine attack versus dosing after the headache has become moderate or severe. Curr Med Res Opin 2004;20(9):1465-1472 Doi: $10.1185 / 030079904 \times 2745$

104. Cady RK, Martin VT, Géraud G, Rodgers A, Zhang $Y$, Ho AP, . . Ramsey KE. Rizatriptan 10-mg ODT for early treatment of migraine and impact of migraine education on treatment response. Headache 2009;49(5):687-696 Doi:10.1111/j.1526$4610.2009 .01412 . x$

105. Carpay HA, Matthiisse P, Steinbuch M and Mulder PG. Oral and subcutaneous sumatriptan in the acute treatment of migraine: an open randomized cross-over study. Cephalalgia 1997;17(5):591-595 Doi:10.1046/j.1468-2982.1997.1705591.x

106. Carpay J, Schoenen J, Ahmad F, Kinrade F and Boswell D. Efficacy and tolerability of sumatriptan tablets in a fast-disintegrating, rapid-release formulation for the acute treatment of migraine: results of a multicenter, randomized, placebo-controlled study. Clin Ther 2004;26(2):214-223 Doi:10.1016/ s0149-2918(04)90020-3

107. Charlesworth BR, Dowson AJ, Purdy A, Becker WJ, Boes-Hansen $S$ and Färkkilä M. Speed of onset and efficacy of zolmitriptan nasal spray in the acute treatment of migraine: a randomised, double-blind, placebo-controlled, dose-ranging study versus zolmitriptan tablet. CNS Drugs 2003; 17(9):653-667 Doi: 10.2165/00023210-200317090-00005

108. Christie S, Göbel H, Mateos V, Allen C, Vrijens $F$ and Shivaprakash M. Crossover comparison of efficacy and preference for rizatriptan $10 \mathrm{mg}$ versus ergotamine/caffeine in migraine. Eur Neurol 2003;49(1):20-29 Doi:10.1159/000067018

109. Colman SS, Brod MI, Krishnamurthy A, Rowland CR, Jirgens KJ and Gomez-Mancilla B. Treatment satisfaction, functional status, and health-related quality of life of migraine patients treated with almotriptan or sumatriptan. Clin Ther 2001;23(1):127. 145 Doi:10.1016/s0149-2918(01)80036-9

110. Connor KM, Aurora SK, Loeys T, Ashina M, Jones C, Giezek $H_{1}$. . . . Ho TW. Long-term tolerability of telcagepant for acute treatment of migraine in a randomized trial. Headache 2011;51(1):73-84 Doi: $10.1111 /$ j. 1526-4610.2010.01799.x

111. Cull RE, Price WH and Dunbar A. The efficacy of subcutaneous sumatriptan in the treatment of recurrence of migraine headache. J Neurol Neurosurg Psychiatry 1997;62(5):490-495 Doi:10.1136/ innp.62.5.490

112. Dahlöf C, Edwards C and Toth A. Sumatriptan injection is superior to placebo in the acute treatment of migraine--with regard to both efficacy and general well-being. Cephalalgia 1992;12(4):214-220 Doi:10.1046/i.1468-2982.1992.1204214.x

113. Diener HC. Efficacy and safety of intravenous acetylsalicylic acid lysinate compared to subcutaneous sumatriptan and parenteral placebo in the acute treatment of migraine. A double-blind, doubledummy, randomized, multicenter, parallel group study. The ASASUMAMIG Study Group. Cephalalgia 1999; 19(6):581-588; discussion 542 Doi:10.1046/ j. 1468-2982.1999.019006581.x

114. Diener HC, Tfelt-Hansen $P$, de Beukelaar F, Ferrari MD, Olesen J, Dahlöf $C$ and Mathew N. The efficacy and safety of sc alniditan vs. sc sumatriptan in the acute treatment of migraine: a randomized, double-blind, placebo-controlled trial. Cephalalgia 2001;21(6):672-679 Doi:10.1046/i.0333 1024.2001.00222.x

115. Diener HC, Jansen JP, Reches A, Pascual J, Pitei 
$D$ and Steiner TJ. Efficacy, tolerability and safety of oral eletriptan and ergotamine plus caffeine (Cafergot) in the acute treatment of migraine: a multicentre, randomised, double-blind, placebocontrolled comparison. Eur Neurol 2002;47(2):99107 Doi: $10.1159 / 000047960$

116. Diener HC. Efficacy of almotriptan $12.5 \mathrm{mg}$ in achieving migraine-related composite endpoints: a double-blind, randomized, placebo-controlled study in patients controlled study in patients with previous poor response to sumatriptan $50 \mathrm{mg}$. Curr Med Res Opin 2005;21(10):1603-1610 Doi: $10.1185 / 030079905 \times 65448$

117. Diener HC, Gendolla A, Gebert I and Beneke M. Almotriptan in migraine patients who respond poorly to oral sumatriptan: a double-blind, randomized trial. Eur Neurol 2005;53 Suppl 1(41-48 Doi:10.1159/000085061

118. Diupesland PG and Docekal P. Intranasal sumatriptan powder delivered by a novel breathactuated bi-directional device for the acute treatment of migraine: A randomised, placebocontrolled study. Cephalalgia 2010;30(8):933-942 Doi:10.1177/0333102409359314

119. Dodick D, Brandes J, Elkind A, Mathew $N$ and Rodichok L. Speed of onset, efficacy and tolerability of zolmitriptan nasal spray in the acute treatment of migraine: a randomised, double-blind, placebocontrolled study. CNS Drugs 2005; 19(2):125-136 Doi:10.2165/00023210-200519020-00003

120. Dowson AJ, Massiou H, Laínez JM and Cabarrocas X. Almotriptan is an effective and welltolerated treatment for migraine pain: results of a randomized, double-blind, placebo-controlled clinical trial. Cephalalgia 2002;22(6):453-461 Doi: 10.1046/j.1468-2982.2002.00394.x

121. Dowson AJ, MacGregor EA, Purdy RA, Becker WJ, Green J and Levy SL. Zolmitriptan orally disintegrating tablet is effective in the acute treatment of migraine. Cephalalgia 2002;22(2):101-106 Doi: 10.1046/j.1468-2982.2002.00319.x

122. Facchinetti F, Bonellie G, Kangasniemi P, Pascual J and Shuaib A. The efficacy and safety of subcutaneous sumatriptan in the acute treatment of menstrual migraine. The Sumatriptan Menstrual Migraine Study Group. Obstet Gynecol 1995;86(6):91 1-916 Doi:10.1016/0029-7844(95)00288-3

123. Färkkilä $M$, Olesen J, Dahlöf $C$, Stovner LJ, ter Bruggen JP, Rasmussen S, . . Sikes C. Eletriptan for the treatment of migraine in patients with previous poor response or tolerance to oral sumatriptan. Cephalalgia 2003;23(6):463-471 Doi:10.1046/ j. 1468-2982.2003.00554.x

124. Ferrari $M D$, James $M H$, Bates $D$, Pilgrim $A$, Ashford E, Anderson BA and Nappi G. Oral sumatriptan: effect of a second dose, and incidence and treatment of headache recurrences. Cephalalgia 1994; 14(5):330-338 Doi:10.1046/j.14682982.1994.1405330.x

125. Freitag FG, Cady R, DiSerio F, Elkind A, Gallagher RM, Goldstein J, ... Smith TR. Comparative study of a combination of isometheptene mucate, dichloralphenazone with acetaminophen and sumatriptan succinate in the treatment of migraine. Headache 2001;41(4):391-398 Doi:10.1046/ j.1526-4610.2001.111006391.x

126. Freitag F, Taylor FR, Hamid MA, Rodgers A, Hustad CM, Ramsey KE and Skobieranda F. Elimination of migraine-associated nausea in patients treated with rizatriptan orally disintegrating tablet (ODT): a randomized, double-blind, placebocontrolled study. Headache 2008;48(3):368-377 Doi: 10.1111 /j.1526-4610.2007.00954.x

127. Friedman BW, Corbo J, Lipton RB, Bijur PE, Esses D, Solorzano C and Gallagher EJ. A trial of metoclopramide vs sumatriptan for the emergency department treatment of migraines. Neurology 2005;64(3):463-468 Doi:10.1212/01. Wnl.0000150904.28131.Dd

128. Friedman BW, Hochberg M, Esses D, Bijur PE, Corbo J, Paternoster J, ... Gallagher EJ. A clinical trial of trimethobenzamide/diphenhydramine versus sumatriptan for acute migraines. Headache 2006;46(6):934-941 Doi: $10.1111 /$ i.1526. 4610.2006.00467.x

129. Friedman MH, Peterson SJ, Behar CF and Zaidi Z. Intraoral chilling versus oral sumatriptan for acute migraine. Heart Dis 2001;3(6):357-361 Doi: 10.1097/00132580-200111000-00003

130. Gallagher RM, Dennish G, Spierings EL and Chitra R. A comparative trial of zolmitriptan and sumatriptan for the acute oral treatment of migraine. Headache 2000;40(2):119-128 Doi:10.1046/ j.1526-4610.2000.00017.x

131. Garcia-Ramos G, MacGregor EA, Hilliard B, Bordini CA, Leston J and Hettiarachchi J. Comparative efficacy of eletriptan vs. naratriptan in the acute treatment of migraine. Cephalalgia 2003;23(9):869876 Doi:10.1046/i.1468-2982.2003.00593.x

132. Geraud G, Olesen J, Pfaffenrath V, Tfelt-Hansen P, Zupping R, Diener HC and Sweet R. Comparison of the efficacy of zolmitriptan and sumatriptan: issues in migraine trial design. Cephalalgia 2000;20(1):3038 Doi:10.1046/j.1468-2982.2000.00004.x 
133. Geraud G, Compagnon A and Rossi A. Zolmitriptan versus a combination of acetylsalicylic acid and metoclopramide in the acute oral treatment of migraine: a double-blind, randomised, threeattack study. Eur Neurol 2002;47(2):88-98 Doi: $10.1159 / 000047959$

134. Ghaderibarmi F, Tavakkoli N and Togha M. Intravenous Valproate versus Subcutaneous Sumatriptan in Acute Migraine Attack. Acta Med Iran 2015;53(10):633-636

135. Gijsman H, Kramer MS, Sargent J, Tuchman M, Matzura-Wolfe $D$, Polis A, . . Ferrari MD. Double-blind, placebo-controlled, dose-finding study of rizatriptan (MK-462) in the acute treatment of migraine. Cephalalgia 1997;17(6):647-651 Doi:10.1046/j.1468-2982.1997.1706647.x

136. Goadsby PJ, Zagami AS, Donnan GA, Symington G, Anthony M, Bladin PF and Lance $\mathrm{JW}$. Oral sumatriptan in acute migraine. Lancet 1991;338(8770):782-783 Doi:10.1016/01406736(91)90666-d

137. Goldstein J, Silberstein SD, Saper JR, Elkind AH, Smith TR, Gallagher RM, ... Baggish J. Acetaminophen, aspirin, and caffeine versus sumatriptan succinate in the early treatment of migraine: results from the ASSET trial. Headache 2005;45(8):973-982 Doi:10.1111/ j.1526-4610.2005.05177.x

138. Goldstein J, Smith TR, Pugach N, Griesser J, Sebree T and Pierce M. A sumatriptan iontophoretic transdermal system for the acute treatment of migraine. Headache 2012;52(9):1402-1410 Doi:10.1111/i.1526-4610.2012.02198.x

139. Gross ML, Kay J, Turner AM, Hallett K, Cleal AL and Hassani $H$. Sumatriptan in acute migraine using a novel cartridge system self-injector. United Kingdom Study Group. Headache 1994;34(10):559-563 Doi:10.1111/j.1526-4610.1994.hed3410559_a.x

140. Gruffyd-Jones K, Kies B, Middleton A, Mulder L, Røsjø $\varnothing$ and Millson DS. Zolmitriptan versus sumatriptan for the acute oral treatment of migraine: a randomized, double-blind, international study. Eur J Neurol 2001;8(3):237-245 Doi:10.1046/i.1468$1331.2001 .00218 . x$

141. Havanka H, Dahlöf C, Pop PH, Diener HC, Winter $\mathrm{P}$, Whitehouse $\mathrm{H}$ and Hassani $\mathrm{H}$. Efficacy of naratriptan tablets in the acute treatment of migraine: a dose-ranging study. Naratriptan S2WB2004 Study Group. Clin Ther 2000;22(8):970-980 Doi:10.1016/ s0149-2918(00)80068-5

142. Henry $P$ and d'Allens $H$. Subcutaneous sumatriptan in the acute treatment of migraine in patients using dihydroergotamine as prophylaxis.
French Migraine Network Bordeaux-LyonGrenoble. Headache 1993;33(8):432-435 Doi:10.1111/i.1526-4610.1993.hed3308432.x

143. Ishkanian $G$, Blumenthal $H$, Webster CJ, Richardson MS and Ames M. Efficacy of sumatriptan tablets in migraineurs self-described or physician-diagnosed as having sinus headache: a randomized, double-blind, placebo-controlled study. Clin Ther 2007;29(1):99-109 Doi:10.1016/i. clinthera.2007.01.012

144. Jelinski SE, Becker WJ, Christie SN, Ahmad FE, Pryse-Phillips W and Simpson SD. Pain free efficacy of sumatriptan in the early treatment of migraine. Can J Neurol Sci 2006;33(1):73-79 Doi:10.1017/ s031716710000473x

145. Jensen K, Tfelt-Hansen P, Hansen EW, Krøis $\mathrm{EH}$ and Pedersen OS. Introduction of a novel selfinjector for sumatriptan. A controlled clinical trial in general practice. Cephalalgia 1995; 15(5):423-429 Doi: 10.1046/i. 1468-2982.1995.1505423.x

146. Kelly AM, Ardagh M, Curry C, D'Antonio J and Zebic $S$. Intravenous chlorpromazine versus intramuscular sumatriptan for acute migraine. J Accid Emerg Med 1997;14(4):209-211 Doi:10.1136/ emj. 14.4.209

147. Kolodny A, Polis A, Battisti WP, Johnson-Pratt L and Skobieranda F. Comparison of rizatriptan 5 $\mathrm{mg}$ and $10 \mathrm{mg}$ tablets and sumatriptan $\mathbf{2 5} \mathrm{mg}$ and $50 \mathrm{mg}$ tablets. Cephalalgia 2004;24(7):540-546 Doi: 10.1111 /j.1468-2982.2004.00707.x

148. Kostic MA, Gutierrez FJ, Rieg TS, Moore TS and Gendron RT. A prospective, randomized trial of intravenous prochlorperazine versus subcutaneous sumatriptan in acute migraine therapy in the emergency department. Ann Emerg Med 2010;56(1):1-6 Doi:10.1016/j.annemergmed.2009.11.020

149. Krymchantowski AV, Filho PF and Bigal ME. Rizatriptan vs. rizatriptan plus trimebutine for the acute treatment of migraine: a double-blind, randomized, cross-over, placebo-controlled study. Cephalalgia 2006;26(7):871-874 Doi:10.1111/ j. 1468-2982.2006.01136.x

150. Láinez MJ, Galván J, Heras J and Vila C. Crossover, double-blind clinical trial comparing almotriptan and ergotamine plus caffeine for acute migraine therapy. Eur J Neurol 2007; 14(3):269-275 Doi: $10.1111 /$ i.1468-1331.2006.01594.x

151. Lines CR, Vandormael K and Malbecq W. A comparison of visual analog scale and categorical ratings of headache pain in a randomized controlled clinical trial with migraine patients. Pain 2001;93(2):185-190 Doi:10.1016/s0304- 
3959(01)00315-3

152. Lipton RB, Stewart WF, Cady R, Hall C, O'Quinn S, Kuhn T and Gutterman D. 2000 Wolfe Award. Sumatriptan for the range of headaches in migraine sufferers: results of the Spectrum Study. Headache 2000;40(10):783-791

Doi:10.1046/i.15264610.2000.00143.x

153. Loder E, Brandes JL, Silberstein S, Skobieranda F, Bohidar N, Wang L, ... Johnson-Pratt L. Preference comparison of rizatriptan ODT 10-mg and sumatriptan 50-mg tablet in migraine. Headache 2001;41(8):745753 Doi:10.1046/j.1526-4610.2001.01138.x

154. Loder E, Silberstein SD, Abu-Shakra S, Mueller L and Smith T. Efficacy and tolerability of oral zolmitriptan in menstrually associated migraine: a randomized, prospective, parallel-group, double-blind, placebocontrolled study. Headache 2004;44(2):120-130 Doi:10.1111/j.1526-4610.2004.04027.x

155. Maghbooli M, Golipour F, Moghimi Esfandabadi $A$ and Yousefi M. Comparison between the efficacy of ginger and sumatriptan in the ablative treatment of the common migraine. Phytother Res 2014;28(3):412415 Doi:10.1002/ptr.4996

156. Marín AC RE, Vargas HC, Medina MJF, Arroyo JVE. Eficacia de la tetracaína intranasal en el ataque agudo de migraña vs. eletriptan por vía oral. Neurol Neurocir Psiquiat 201 1;44(3):81-87

157. Mathew NT, Asgharnejad $M$, Peykamian $M$ and Laurenza A. Naratriptan is effective and well tolerated in the acute treatment of migraine. Results of a double-blind, placebo-controlled, crossover study. The Naratriptan S2WA3003 Study Group. Neurology 1997;49(6):1485-1490 Doi:10.1212/ wnl.49.6.1485

158. Mathew NT, Kailasam J and Meadors L. Early treatment of migraine with rizatriptan: a placebocontrolled study. Headache 2004;44(7):669-673 Doi: $10.1111 /$ i.1526-4610.2004.04125.x

159. Mathew NT, Finlayson G, Smith TR, Cady RK, Adelman J, Mao L, . . . Greenberg SJ. Early intervention with almotriptan: results of the AEGIS trial (AXERT Early Migraine Intervention Study). Headache 2007;47(2):189-198 Doi:10.1111/ i. 1526-4610.2006.00686.x

160. McGinley JS, Buse DC, Shulman KJ, Wirth RJ, Hugentobler E and Lipton RB. Evaluating Mean Level and Within-Person Consistency in Migraine Pain Intensity and Migraine-Related Disability for AVP-825 vs Oral Sumatriptan: Results from the COMPASS Study, A Randomized Trial. Headache 2019;59(7):10021013 Doi:10.1111/head. 13530

161. Meredith JT, Wait S and Brewer KL. A prospective double-blind study of nasal sumatriptan versus IV ketorolac in migraine. Am J Emerg Med 2003;21(3):173-175 Doi:10.1016/s07356757(02)42256-5

162. Miljković S, Smajlović D, Tirić Campara M, Jurina $R$, Duranović Vinković L, Janković SM, . . Ćeranić M. The first comparative double-blind trial on efficacy and safety of ergotamine based five-component combination and sumatriptan in migraine without aura. Hippokratia 2018;22(1):17-22

163. Di Monda V, Nicolodi M, Aloisio A, Del Bianco P, Fonzari M, Grazioli I, . . . Sicuteri F. Efficacy of a fixed combination of indomethacin, prochlorperazine, and caffeine versus sumatriptan in acute treatment of multiple migraine attacks: a multicenter, randomized, crossover trial. Headache 2003;43(8):835-844 Doi:10.1046/j.1526-4610.2003.03161.x

164. Moon HS, Chu MK, Park JW, Oh K, Chung JM, Cho YJ, . . . Kwon SU. Frovatriptan is Effective and Well Tolerated in Korean Migraineurs: A Double-Blind, Randomized, Placebo-Controlled Trial. J Clin Neurol 2010;6(1):27-32 Doi:10.3988/icn.2010.6.1.27

165. Moshtaghion $\mathrm{H}$, Heiranizadeh N, Rahimdel A, Esmaeili A, Hashemian $\mathrm{H}$ and Hekmatimoghaddam S. The Efficacy of Propofol vs. Subcutaneous Sumatriptan for Treatment of Acute Migraine Headaches in the Emergency Department: A Double-Blinded Clinical Trial. Pain Pract 2015;15(8):701-705 Doi:10.1111/ papr. 12230

166. Müller T and Lohse L. Efficacy of parecoxib, sumatriptan, and rizatriptan in the treatment of acute migraine attacks. Clin Neuropharmacol 2011;34(6):206-209 Doi:10.1097/ WNF.0b013e31823429cd

167. Myllylä VV, Havanka H, Herrala L, Kangasniemi P, Rautakorpi I, Turkka J, . . . Eskerod O. Tolfenamic acid rapid release versus sumatriptan in the acute treatment of migraine: comparable effect in a doubleblind, randomized, controlled, parallel-group study. Headache 1998;38(3):201-207 Doi:10.1046/ j. 1526-4610.1998.3803201.x

168. Nappi G, Sicuteri F, Byrne $M$, Roncolato $M$ and Zerbini $O$. Oral sumatriptan compared with placebo in the acute treatment of migraine. J Neurol 1994;241(3):138-144 Doi:10.1007/bf00868340

169. Treatment of migraine attacks with sumatriptan. N Engl J Med 1991;325(5):316-321 Doi:10.1056/ nejm 199108013250504

170. A randomized, double-blind comparison of sumatriptan and Cafergot in the acute treatment of migraine. The Multinational Oral Sumatriptan and Cafergot Comparative Study Group. Eur Neurol 
1991;31(5):314-322 Doi:10.1159/000116759

171. Pascual J, Vega P, Diener HC, Allen C, Vrijens $\mathrm{F}$ and Patel $\mathrm{K}$. Comparison of rizatriptan $10 \mathrm{mg}$ vs. zolmitriptan $2.5 \mathrm{mg}$ in the acute treatment of migraine. Rizatriptan-Zolmitriptan Study Group. Cephalalgia 2000;20(5):455-461 Doi:10.1046/ j. 1468-2982.2000.00069.x

172. Pascual J, Falk RM, Piessens F, Prusinski A, Docekal P, Robert M, . . Zayas JM. Consistent efficacy and tolerability of almotriptan in the acute treatment of multiple migraine attacks: results of a large, randomized, double-blind, placebo-controlled study. Cephalalgia 2000;20(6):588-596 Doi:10.1046/ j. 1468-2982.2000.00091.x

173. Pini LA, Sternieri E, Fabbri L, Zerbini $O$ and Bamfi F. High efficacy and low frequency of headache recurrence after oral sumatriptan. The Oral Sumatriptan Italian Study Group. J Int Med Res 1995;23(2):96105 Doi:10.1177/030006059502300202

174. Pini LA, Guerzoni S, Cainazzo M, Ciccarese M, Prudenzano MP and Livrea P. Comparison of tolerability and efficacy of a combination of paracetamol + caffeine and sumatriptan in the treatment of migraine attack: a randomized, double-blind, double-dummy, cross-over study. J Headache Pain 2012;13(8):669675 Doi: 10.1007/s 10194-012-0484-z

175. Rahimdel A, Mellat A, Zeinali A, Jafari $E$ and Ayatollahi P. Comparison between Intravenous Sodium Valproate and Subcutaneous Sumatriptan for Treatment of Acute Migraine Attacks; Double-Blind Randomized Clinical Trial. Iran J Med Sci 2014;39(2 Suppl): 171-177

176. Rao AS, Gelaye B, Kurth T, Dash PD, Nitchie $\mathrm{H}$ and Peterlin BL. A Randomized Trial of Ketorolac vs. Sumatripan vs. Placebo Nasal Spray (KSPN) for Acute Migraine. Headache 2016;56(2):331-340 Doi: 10.1111 /head. 12767

177. Rapoport AM, Ramadan NM, Adelman JU, Mathew NT, Elkind AH, Kudrow DB and Earl NL. Optimizing the dose of zolmitriptan (Zomig, 311C90) for the acute treatment of migraine. A multicenter, double-blind, placebo-controlled, dose rangefinding study. The 017 Clinical Trial Study Group. Neurology 1997;49(5):1210-1218 Doi:10.1212/ wnl.49.5.1210

178. Rothner $A D$, Wasiewski W, Winner $P$, Lewis $D$ and Stankowski J. Zolmitriptan oral tablet in migraine treatment: high placebo responses in adolescents. Headache 2006;46(1):101-109 Doi:10.1111/ j.1526-4610.2006.00313.x

179. Russell MB, Holm-Thomsen OE, Rishøj Nielsen $M$, Cleal A, Pilgrim AJ and Olesen J. A randomized double-blind placebo-controlled crossover study of subcutaneous sumatriptan in general practice. Cephalalgia 1994;14(4):291-296 Doi:10.1046/ j. 1468-2982.1994.1404291.x

180. Sandrini G, Cerbo R, Del Bene E, Ferrari A, Genco S, Grazioli I, . . Zanchin G. Efficacy of dosing and re-dosing of two oral fixed combinations of indomethacin, prochlorperazine and caffeine compared with oral sumatriptan in the acute treatment of multiple migraine attacks: a doubleblind, double-dummy, randomised, parallel group, multicentre study. Int J Clin Pract 2007;61(8):1256. 1269 Doi: $10.1111 /$ j.1742-1241.2007.01458.x

181. Sang CN, Ramadan NM, Wallihan RG, Chappell AS, Freitag FG, Smith TR, . . Vandenhende F. LY293558, a novel AMPA/GluR5 antagonist, is efficacious and well-tolerated in acute migraine. Cephalalgia 2004;24(7):596-602 Doi:10.1111/ i. 1468-2982.2004.00723.x

182. Savi L, Mogavero S and Egan CG. Efficacy and pharmacokinetic activity of frovatriptan compared to rizatriptan in patients with moderate-to-severe migraine. Drug Des Devel Ther 2014;8(983-992 Doi: $10.2147 /$ dddt.S6 1295

183. Schulman EA. Transdermal sumatriptan for acute treatment of migraineurs with baseline nausea. Headache 2012;52(2):204-212 Doi:10.1111/ j. 1526-4610.2011 1.02065.x

184. Scott RJ, Aitchison WR, Barker PR and McLaren $\mathrm{Gl}$. Oral sumatriptan in the acute treatment of migraine and migraine recurrence in general practice. Qjm 1996;89(8):613-622 Doi:10.1093/ qimed/89.8.613

185. Seeburger JL, Taylor FR, Friedman D, Newman L, Ge Y, Zhang Y, . . Connor KM. Efficacy and tolerability of rizatriptan for the treatment of acute migraine in sumatriptan nonresponders. Cephalalgia 2011;31(7):786-796 Doi: $10.1177 / 0333102410390399$

186. Seeburger JL, Cady RK, Winner P, MacGregor A, Valade $D, G e Y, \ldots$ Ho TW. Rizatriptan for treatment of acute migraine in patients taking topiramate for migraine prophylaxis. Headache 2012;52(1):57-67 Doi:10.1111/i.1526-4610.2011.02027.x

187. Sheftell FD, Dahlöf CG, Brandes JL, Agosti R, Jones MW and Barrett PS. Two replicate randomized, double-blind, placebo-controlled trials of the time to onset of pain relief in the acute treatment of migraine with a fast-disintegrating/rapid-release formulation of sumatriptan tablets. Clin Ther 2005;27(4):407417 Doi:10.1016/i.clinthera.2005.04.003

188. Silberstein SD, Elkind AH, Schreiber $C$ and 
Keywood C. A randomized trial of frovatriptan for the intermittent prevention of menstrual migraine. Neurology 2004;63(2):261-269 Doi:10.1212/01. wnl.0000134620.30129.d6

189. Solomon GD, Cady RK, Klapper JA, Earl NL, Saper JR and Ramadan NM. Clinical efficacy and tolerability of $2.5 \mathrm{mg}$ zolmitriptan for the acute treatment of migraine. The 042 Clinical Trial Study Group. Neurology 1997;49(5):1219-1225 Doi:10.1212/wnl.49.5.1219

190. Spierings EL, Gomez-Mancilla B, Grosz DE, Rowland CR, Whaley FS and Jirgens KJ. Oral almotriptan vs. oral sumatriptan in the abortive treatment of migraine: a double-blind, randomized, parallel-group, optimum-dose comparison. Arch Neurol 2001;58(6):944-950 Doi:10.1001/ archneur.58.6.944

191. Spierings EL, Rapoport AM, Dodick DW and Charlesworth B. Acute treatment of migraine with zolmitriptan $5 \mathbf{~ m g}$ orally disintegrating tablet. CNS Drugs 2004;18(15):1133-1141 Doi: 10.2165/00023210-200418150-00007

192. Spierings EL and Keywood C. Rapid responders to frovatriptan in acute migraine treatment: results from a long-term, open-label study. Pain Med 2009; 10(4):633-638 Doi:10.1111/i.15264637.2009.00618.x

193. Stark S, Spierings EL, McNeal S, Putnam GP, Bolden-Watson CP and O'Quinn S. Naratriptan efficacy in migraineurs who respond poorly to oral sumatriptan. Headache 2000;40(7):513-520 Doi:10.1046/j.1526-4610.2000.00082.x

194. Stark R, Dahlöf C, Haughie S and Hettiarachchi $J$. Efficacy, safety and tolerability of oral eletriptan in the acute treatment of migraine: results of a phase III, multicentre, placebo-controlled study across three attacks. Cephalalgia 2002;22(1):23-32 Doi:10.1046/j.1468-2982.2002.00300.x

195. Steiner TJ, Diener HC, MacGregor EA, Schoenen J, Muirheads $N$ and Sikes CR. Comparative efficacy of eletriptan and zolmitriptan in the acute treatment of migraine. Cephalalgia 2003;23(10):942-952 Doi:10.1046/j.1468-2982.2003.00617.x

196. Talabi S, Masoumi B, Azizkhani R and Esmailian $M$. Metoclopramide versus sumatriptan for treatment of migraine headache: A randomized clinical trial. J Res Med Sci 2013;18(8):695-698

197. Teall J, Tuchman M, Cutler N, Gross M, Willoughby E, Smith B, . . Block G. Rizatriptan (MAXALT) for the acute treatment of migraine and migraine recurrence. A placebo-controlled, outpatient study. Rizatriptan 022 Study Group. Headache 1998;38(4):281-287
Doi:10.1046/j.1526-4610.1998.3804281.x

198. Tepper SJ, Donnan GA, Dowson AJ, Bomhof MA, Elkind A, Meloche J, ... Millson DS. A long-term study to maximise migraine relief with zolmitriptan. Curr Med Res Opin 1999;15(4):254271 Doi:10.1185/03007999909116496

199. Tepper SJ, Cady R, Dodick D, Freitag FG, Hutchinson SL, Twomey C and Kuhn TA. Oral sumatriptan for the acute treatment of probable migraine: first randomized, controlled study. Headache 2006;46(1):115-124 Doi:10.1111/ j. 1526-4610.2006.00300.x

200. Tfelt-Hansen P, Henry P, Mulder L, Scheldewaert RG, Schoenen J and Chazot G. The effectiveness of combined oral lysine acetylsalicylate and metoclopramide compared with oral sumatriptan for migraine. Lancet 1995;346(8980):923-926 Doi:10.1016/s0140-6736(95)91554-0

201. Tfelt-Hansen P, Teall J, Rodriguez F, Giacovazzo M, Paz J, Malbecq W, ... Visser WH. Oral rizatriptan versus oral sumatriptan: a direct comparative study in the acute treatment of migraine. Rizatriptan 030 Study Group. Headache 1998;38(10):748-755 Doi: 10.1046/j.1526-4610.1998.3810748.x

202. Tfelt-Hansen P, Bach FW, Daugaard D, Tsiropoulos I and Riddersholm B. Treatment with sumatriptan $50 \mathrm{mg}$ in the mild phase of migraine attacks in patients with infrequent attacks: a randomised, double-blind, placebo-controlled study. J Headache Pain 2006;7(6):389-394 Doi:10.1007/ s10194-006-0333-z

203. A study to compare oral sumatriptan with oral aspirin plus oral metoclopramide in the acute treatment of migraine. The Oral Sumatriptan and Aspirin plus Metoclopramide Comparative Study Group. Eur Neurol 1992;32(3):177-184 Doi: $10.1159 / 000116818$

204. Evaluation of a multiple-dose regimen of oral sumatriptan for the acute treatment of migraine. The Oral Sumatriptan International Multiple-Dose Study Group. Eur Neurol 1991;31(5):306-313 Doi: $10.1159 / 000116758$

205. Self-treatment of acute migraine with subcutaneous sumatriptan using an auto-injector device. The Sumatriptan Auto-Injector Study Group. Eur Neurol 1991;31(5):323-331 Doi:10.1159/000116760

206. Touchon J, Bertin L, Pilgrim AJ, Ashford E and Bès $A$. A comparison of subcutaneous sumatriptan and dihydroergotamine nasal spray in the acute treatment of migraine. Neurology 1996;47(2):361365 Doi:10.1212/wnl.47.2.361

207. Visser WH, Ferrari MD, Bayliss EM, Ludlow $S$ and 
Pilgrim AJ. Treatment of migraine attacks with subcutaneous sumatriptan: first placebo-controlled study. The Subcutaneous Sumatriptan International Study Group. Cephalalgia 1992;12(5):308-313 Doi:10.1046/j. 1468-2982.1992.1205308.x

208. Visser WH, Terwindt GM, Reines SA, Jiang K, Lines $C R$ and Ferrari MD. Rizatriptan vs sumatriptan in the acute treatment of migraine. A placebo-controlled, dose-ranging study. Dutch/US Rizatriptan Study Group. Arch Neurol 1996;53(11):1 132-1137 Doi:10.1001/ archneur. 1996.00550110072014

209. Wang SJ, Fuh JL and Wu ZA. Intranasal sumatriptan study with high placebo response in Taiwanese patients with migraine. I Chin Med Assoc 2007;70(2):39-46 Doi:10.1016/s17264901(09)70300-4
210. Wendt J, Cady R, Singer R, Peters K, Webster C, Kori $S$ and Byrd S. A randomized, double-blind, placebocontrolled trial of the efficacy and tolerability of a 4-mg dose of subcutaneous sumatriptan for the treatment of acute migraine attacks in adults. Clin Ther 2006;28(4):517. 526 Doi:10.1016/i.clinthera.2006.03.013

211. Winner P, Ricalde O, Le ForceB, Saper J and Margul B. A double-blind study of subcutaneous dihydroergotamine vs subcutaneous sumatriptan in the treatment of acute migraine. Arch Neurol 1996;53(2):180-184 Doi:10.1001/archneur. 1996.00550020092020

212.Zhang A, Jiang T, Luo Y, Zheng Z, Shi X, Xiao Z and Fang $Y$. Efficacy of intravenous propacetamol hydrochloride in the treatment of an acute attack of migraine. Eur J Intern Med 2014;25(7):629-632 Doi:10.1016/i. ejim.2014.06.007 